Universidade de Brasília

Instituto de Biologia

Departamento de Botânica

Programa de Pós-Graduação em Botânica

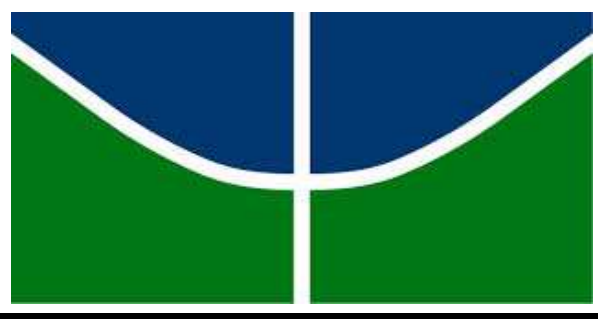

\title{
REVISÃO TAXONÔMICA E FILOGENIA MOLECULAR DE CHRYSO-HYPNUM \\ HAMPE E MITTENOTHAMNIUM HENNING (HYPNACEAE), PARA O NEOTRÓPICO
}

OSVANDA SILVA DE MOURA

ORIENTADOR: PAULO EDUARDO AGUIAR SARAIVA CÂMARA

Brasília

Dezembro, 2016 
Universidade de Brasília

Instituto de Biologia

Departamento de Botânica

Programa de Pós-Graduação em Botânica
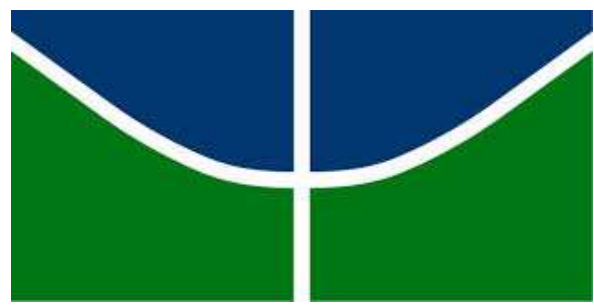

\section{REVISÃO TAXONÔMICA E FILOGENIA MOLECULAR DE CHRYSO-HYPNUM \\ HAMPE E MITTENOTHAMNIUM HENNING (HYPNACEAE), PARA O NEOTRÓPICO}

OSVANDA SILVA DE MOURA

Tese apresentada ao Programa de PósGraduação em Botânica da Universidade de Brasília, como parte dos requisitos necessários para obtenção do título de DOUTOR EM BOTÂNICA.

ORIENTADOR: PAULO EDUARDO AGUIAR SARAIVA CÂMARA

Brasília

Dezembro, 2016 


\section{Revisão Taxonômica e Filogenia Molecular de Chryso-hypnum Hampe e Mittenothamnium Henning (Hypnaceae) para o Neotrópico}

Tese apresentada e aprovada em 09 de dezembro de 2016

Dr. Paulo Eduardo Aguiar Saraiva Câmara

Orientador e Presidente da Banca

Universidade de Brasília

Dr. Lucas Matheus da Rocha

Membro externo

Universidade Federal de Uberlândia

Dr. Luciano Coêlho Milhomens Fonsêca

Membro Externo

Universidade Católica de Brasília

Dr. Diego Knop Henriques

Universidade de Brasília

Dra. Cássia B. R. Munhoz

Membro Vinculado ao Programa

Universidade de Brasília

Dra. Maria das Graças Machado

Suplente

Universidade de Brasília 


\section{DEDICATÓRIA}

- Aos meus adoráveis pais Francisca Osmarina Silva e Valdenir Ferreira de Moura, que mesmo distantes fisicamente, mantiveram-se ao meu lado desejando e lutando pelo meu sucesso e cujo carinho, confiança e amor me enriquecem.

Ao meu esposo, amigo e companheiro Ivanir Alves da Silva que SEMPRE foi meu modelo de inspiração!

E a todos os briólogos iniciantes... 
“É sábio reconhecer a necessidade, quando todas as outras soluções já foram ponderadas, embora possa parecer tolice para aqueles que têm falsas esperanças" (J. R. R. Tolkien) 


\section{AGRADECIMENTOS}

À Coordenação de Aperfeiçoamento de Pessoal de Nível Superior - CAPES, pela concessão da bolsa de doutorado e do doutorado sanduíche no Jardim Botânico de Nova Iorque.

Ao Programa de Pós-Graduação em Botânica da Universidade de Brasília, que possibilitou a realização desta tese.

Ao meu orientador Dr. Paulo Eduardo Aguiar Saraiva Câmara por ter aceitado o desafio e a confiança de me orientar, por todo seu empenho em me ajudar nesse "fantástico mundo das briófitas", por sua valiosa dedicação, qualidade profissional indiscutível, amizade, respeito, pelos momentos de descontração, pelos ensinamentos de vida, uma verdadeira inspiração profissional, minha eterna gratidão!

À banca examinadora por terem aceitado participar da avaliação deste trabalho, Dr. Diego Knop Henrique (Picachu), Dr. Lucas Matheus Rocha, Dra. Maria das Graças Machado e a Dra. Cássia Munhoz.

Ao Dr. Willian R. Buck por me receber tão bem no Jardim Botânico de Nova Iorque e pelos auxílios durante minha estadia em NY. O mesmo agradecimento ao Dr. Bruce Allen do Jardim Botânico de Missouri.

A todos os companheiros do Laboratório de Criptógamas e do NUBRIOCO (Núcleo de Briólogos do Centro-Oeste) pelos vários momentos de discussão, aprendizagem, apoio e descontração. Especialmente as amigas Júlia Viegas Mundin, por sua eterna paciência, bondade inquestionável em ajudar a todos, a querida Tamara Dantas por toda vez que me ajudou com os programas de filogenia e dúvidas sobre o assunto. A Carla Pereira Gomes por todos os conselhos e apoio nos momentos bad! A Dra. Ana Gabriela Duarte-Silva pela ajuda e pelos inúmeros conselhos profissionais. E ao Dr. Allan Faria pelos momentos de muita descontração, risadas e alegrias no laboratório de Criptógamas.

À minha amiga do coração Francismeire Bonadeu da Silva (Salsichão) pelos dias de descontração, alegrias, desabafo e inúmeras aventuras de campo. Pelos anos em que convivemos juntas desde a graduação (época em que insistiu fazer parte da minha vida) e agora na luta pelo término das nossas teses (mais um desafio!). 
Ao casal de biólogos mais "chatos adoráveis" que conheci: Dra. Ana Kelly Koch e Dr. Lucas Eduardo Araújo, meus amigos do coração, pela companhia, amizade, apoio, atenção e acima de tudo pelas risadas, que mesmo estamos distantes ainda continuam.

À família Moura, em especial minhas irmãs (Lena e Vanessa), e ao meu irmão caçula Dérik que, apesar da distância, sempre estiveram perto de mim por meio de apoio, preocupações, incentivos, carinho e amor. A eles devo tudo o que sou.

À família Silva, principalmente a minha cunhada Luciene e a minha sogra Lucinea, as quais sempre me apoiaram e me desejaram muito sucesso profissional.

E a todos aqueles que sempre torceram por mim, mesmo os que não foram citados, meu profundo agradecimento e carinho. 


\section{SUMÁRIO}

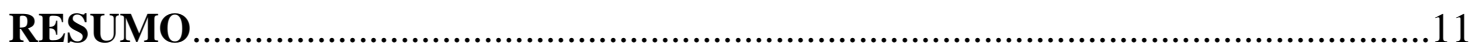

ABSTRACT

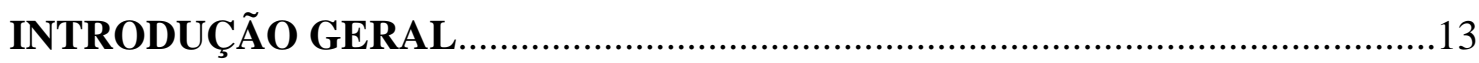

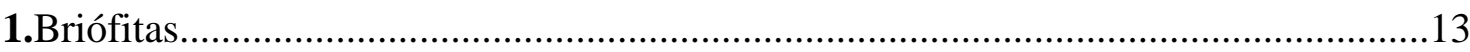

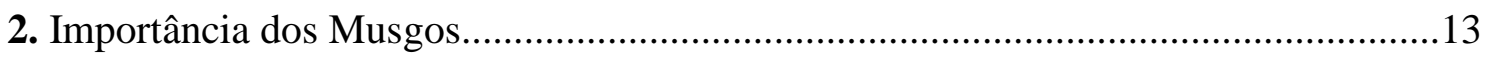

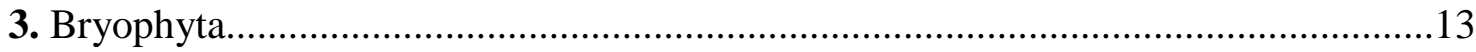

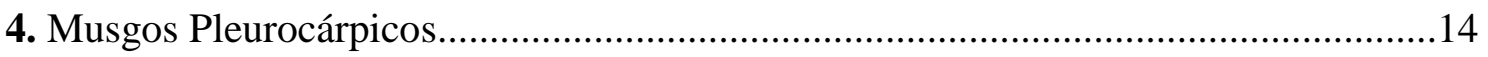

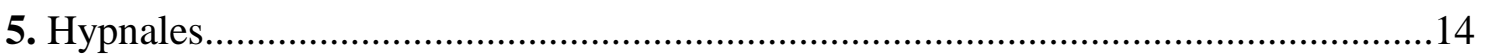

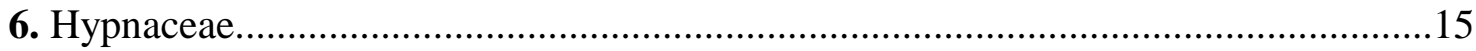

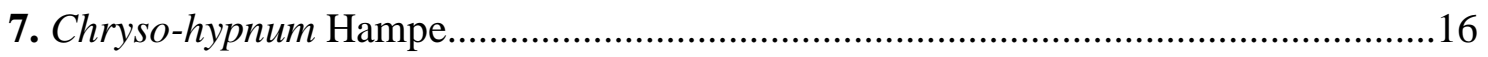

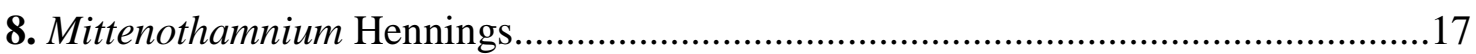

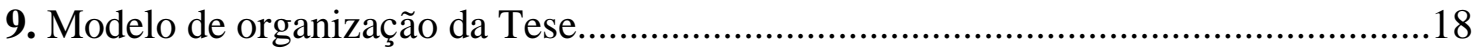

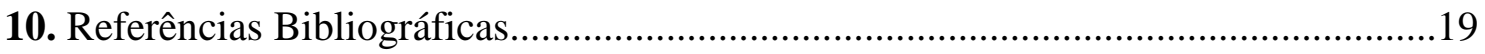

\section{CAPÍTULO 1}

Uma abordagem filogenética de Chryso-hypnum Hampe (Pylaisiaceae) e Mittenothamnium Hennings (Hypnaceae), usando os marcadores ITS, 26S e rps4.

Resumo

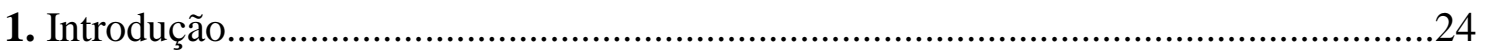

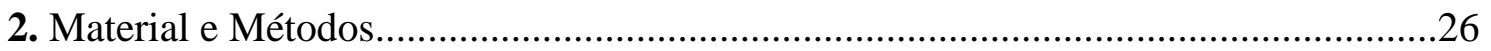

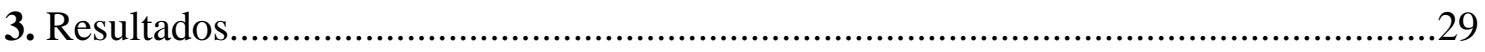

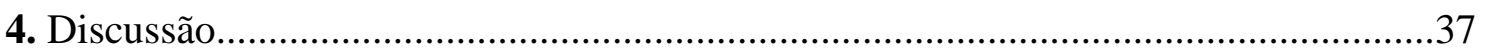

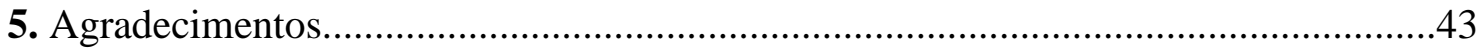




\section{CAPÍTULO 2}

Morfologia dos esporos e desenvolvimento das papilas (células proradas) nos filídios de Chryso-hypnum Hampe e Mittenothamnium Hennings (Hypnaceae).

Resumo .55

1. Introdução. .57

2. Material e Métodos. .60

3. Resultados .61

4. Discussão .63

5. Agradecimentos .66

6. Referências Bibliográficas .66

\section{CAPÍTULO 3}

Revisão taxonômica de Mittenothamnium Hennings (Hypnaceae) para região Neotropical.

Resumo 83

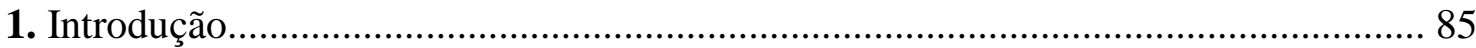

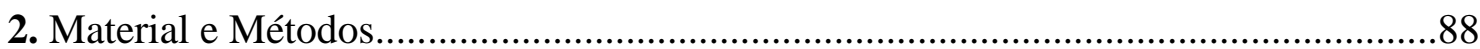

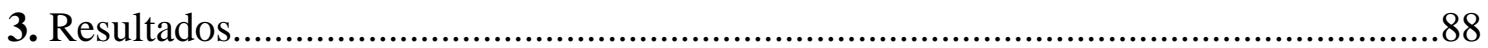

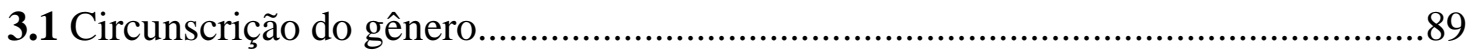

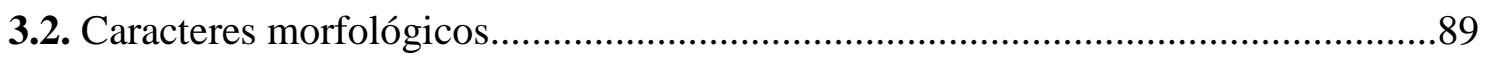

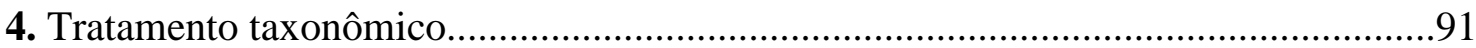

Chave de identificação para as espécies de Mittenothamnium encontradas na região Neotropical. 
5. Tipos não vistos.

6. Nomes inválidos.

133

7. Sinonimização de algumas espécies de Mittenothamnium para outros gêneros

8. Novas combinações para espécies excluídas de

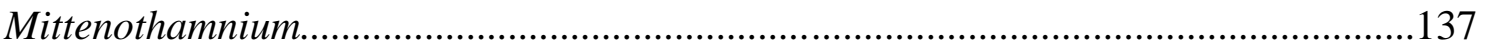

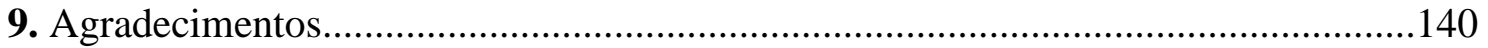

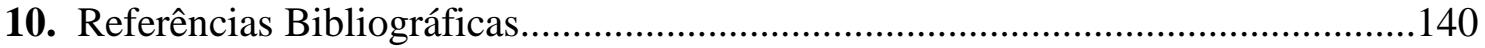




\section{RESUMO}

A família Hypnaceae pertence ao grupo dos musgos pleurocárpicos, ordem Hypnales. É uma família cosmopolita que coloniza diversos substratos e muitos de seus representantes exercem um papel ecológico importante. Estima-se que a família seja composta por 1.000 espécies e 40 gêneros, distribuídas em regiões tropicais e temperadas do mundo. O objetivo deste trabalho foi realizar uma revisão taxonômica dos gêneros Chryso-hypnum (in. prep.) e Mittenothamnium para o neotrópico; apresentar uma hipótese filogenética com uso de marcadores moleculares para esses dois gêneros a nível mundial e determinar quais são caracteres morfológicos informativos para separar os gêneros e espécies de Hypnaceae. Para tanto, a tese está subdividida em três capítulos. O primeiro aborda a filogenia molecular de Chrysohypnum e Mittenothamnium baseada em marcadores de cloroplasto e núcleo. Neste capítulo foram produzidas 43 novas sequências. Três regiões de dois genomas foram utilizadas: rps4, ITS e 26S. Em todas as análises foi possível observar o polifiletismo de Chryso-hypnum e o monofiletismo de Mittenothamnium. O segundo capítulo aborda a morfologia dos esporos e desenvolvimento das papilas em Chryso-hypnum e Mittenothamnium. Observa-se que as espécies pertencentes ao gênero Chryso-hypnum apresentam papilas em ambas as extremidades das células dos filídios, enquanto que Mittenothamnium apresentam espécies com papilas apenas no ápice da célula. Já os esporos de Chryso-hypnum apresentam ornamentação com grânulos de tamanho variável formados pela fusão de nanogrânulos. E em Mittenothamnium, os esporos apresentam disposição dos grânulos na superfície da parede que se dá de forma esparsa e irregular. E o terceiro capítulo refere-se à revisão taxonômica de Mittenothamnium para o neotrópico, onde foram estudadas exsicatas provenientes de diversos herbários nacionais e internacionais e o material-tipo de todas as espécies com seus registros de ocorrência. Neste capítulo estão sendo tratadas nove espécies de Mittenothamnium para o neotrópico. Duas novas ocorrências (uma para o Brasil e a outra para o Equador) são apresentadas.

Palavras-chaves: Chryso-hypnum, Mittenothamnium, Filogenia, Esporos, Papilas, Taxonomia. 


\begin{abstract}
The Hypnaceae family belongs to the pleurocarpous mosses and the Hypnales Order. It is a cosmopolitan family that colonizes a large tips of substrates, having an important ecological function in their environment. 1.000 species from 40 genus are worldwide estimated for the family distributed in tropical and temperate regions. This work objective is to realize a taxonomic revision of the Chryso-hypnum Hampe and Mittenothamnium Henn. genus for Neotropics; present a phylogenetic hypothesis by using molecular markers for the two genus in a worldwide level and determine wich are informative morphological characters to separate the genus and species of Hypnaceae. The thesis is dividing in three chapters. The first one is about a molecular phylogeny of Chryso-hypnum and Mittenothamnium based on nucleus and chloroplast markers. In this chapter 43 new sequences were produced. Three regions and two genomes were used: rps4, ITS and 26S. In all the analyzes was possible to identify the polyphyly of the Chryso-hypnum and the monophyly of the Mittenothamnium. The second chapter refers to morphology of the spores and development of leaf papillae (prorates cells) in the Chryso-hypnum and Mittenothamnium (Hypnaceae). It is observed that Chryso-hypnum has papillae on both ends of the leaf cells, while Mittenothamnium presents species with papillae only at the apex of the leaf cell. Chryso-hypnum spores presents ornaments with granules of variable size formed by the fusion of nanogranules. And in Mittenothamnium the spores present arrangement of the granules in the surface of the wall that is of sparse and irregular form. The third chapter refers to the taxonomic revision of Mittenothamnium to the Neotropic, where exsicates from several national and international herbariums were studied and the types material of all species with their occurrence records. Nine species have been included and an identification key for the genus has been made. Descriptions, nomenclature notes, distribution maps, illustrations and the conservation status have been constructed for each species. Two new occurrences (one for Brazil and the other for Ecuador) are presented.
\end{abstract}

Keywords: Chryso-hypnum, Mittenothamnium, Phylogeny, Spores, Papillae, Taxonomy 


\section{INTRODUÇÃO GERAL}

\section{Briófitas}

As briófitas sensu latu correspondem, em número de espécies, ao segundo maior grupo de plantas terrestres existentes (Buck \& Goffinet 2000), perdendo somente para as angiospermas, e formam um grupo de plantas altamente diversificada, com ampla distribuição, habitando todos os continentes do mundo (Goffinet \& Shaw 2009). Elas formam um grupo parafilético (Qiu et al. 2006, Buck \& Goffinet 2000) e se subdividem em três linhagens: as hepáticas, mais basais e representadas pela divisão Marchantiophyta (Crandald-Stotler \& Stotler 2000), os musgos, respresentados pela divisão Bryophyta e os antóceros, grupo mais derivado e constituinte da divisão Anthocerothophyta (Goffinet \& Shaw 2009).

\section{Importância dos musgos}

Apesar do tamanho muito pequeno, esse grupo vegetal apresenta importantes funções ecológicas como bioindicadores da qualidade do ar e água (Ando \& Matsuo 1984; Fernández \& Serrano 2009). Apresentam a formação de extensos tapetes os quais contribuem para o controle da erosão e, frequentemente servem de substrato para o desenvolvimento de outros vegetais (Zartman 2003). Briófitas também possuem atividade anticancerígena, anti-inflamatória, alelopática e são produtoras de antibióticos e antivirais (Welch 1948, Fernández \& Serrano 2009). Têm sido muito utilizadas também como organismos modelos em estudos de desenvolvimento celular em biologia molecular (Cuming 2009). Embora seu papel ecológico ainda não tenha sido suficientemente estudado, sabe-se que diversas espécies animais, tais como tardígrados, vivem exclusivamente sobre musgos durante toda sua vida (Welch 1948; Ando \& Matsuo 1984).

\section{Bryophyta}

A divisão Bryophyta, que compreende apenas os musgos, corresponde cerca de 13.000 espécies, que formam o grupo mais diverso dentro das briófitas (sensu lato) (Goffinet \& Shaw, 2009). Apresentam o gametófito composto por um caulídio ereto ou rastejante, no qual se inserem filídios dispostos espiraladamente, e por rizóides pluricelulares (Gradstein et al. 2001). Os musgos podem ser divididos em três 
importantes grupos com base na origem e posição do periquécio (região do gametófito feminino onde ocorre a fecundação e na qual vai se originar o esporófito): acrocárpicos, cladocárpicos ou pleurocápicos (Goffinet e Shaw 2009).

Os acrocárpicos possuem crescimento monopodial. Apresentam esporófito produzido no ápice do ramo, ou seja, tem o periquécio terminalmente no eixo principal. Os pleurocárpicos apresentam crescimento simpodial, e o esporófito é desenvolvido a partir de um simples botão periquecial especializado, ou seja, o periquécio se localiza lateralmente no ramo. E os cladocárpicos também apresentam crescimento simpodial, mas o esporófito se desenvolve no ápice da ramificação (La Farge-England 1996).

\section{Musgos Pleurocárpicos}

Os musgos pleurocárpicos são um grupo monofilético (De Luna et al. 1999, Newton et al. 2000), que constituem uma linhagem altamente diversificada com aproximadamente $42 \%$ das 13.000 espécies de musgos (Newton et al. 2007), sendo representados por três ordens, separadas principalmente, de acordo com a arquitetura do peristômio: Hookeriales, Ptychomniales e Hypnales (Buck et al. 2005, Newton et al. 2007), sendo esta última a detentora de $80 \%$ das espécies de musgos pleurocárpicos, apresentando-se como uma das ordens mais diversificada em número de espécies da divisão Bryophyta (Goffinet \& Buck 2004).

Os musgos pleurocárpicos surgiram há cerca de 165-131 milhões de anos, no período Cretáceo, juntamente com o aparecimento das florestas de angiospermas no cenozóico primitivo. Isso pode ser explicado pelas novas condições ambientais proporcionadas pelas angiospermas, como o aumento da umidade e a menor incidência de radiação solar, que são essenciais para as briófitas (Newton et al. 2007). O tempo absoluto da diversificação dos musgos pleurocárpicos ainda é uma incógnita, mas já é bem estabelecido que os mesmos representem um clado derivado (Shaw et al. 2003).

A posição filogenética derivada, com os ramos muito curtos na base do clado e o baixo nível de diversidade de nucleotídeo distinguindo seus táxons, sugerem que os musgos pleurocárpicos, bastante ricos em espécies, representem uma radiação relativamente recente e rápida dentro das Bryophyta (Shaw et al. 2003).

\section{Hypnales}


Hypnales é a maior e mais diversificada ordem de musgos pleurocárpicos (Goffinet \& Buck 2004). Análises filogenéticas de dados moleculares sugerem que a diversidade dos pleurocárpicos ocorreu num curto período de tempo (Newton et al. 2007). A ausência de um bom registro fóssil tem dificultado as tentativas para determinar quando este grupo evoluiu e os processos envolvidos (Newton et al. 2007).

Shaw et al. (2003) em estudos moleculares sobre a diversificação dos musgos pleurocárpicos, concluíram que as Hypnales apresentam a evidência de uma rápida diversificação nos primeiros $20 \%$ de sua história evolutiva, mas que seu grupo irmão, as Hookeriales não. Essa rápida diversificação das Hypnales provocou uma menor diversidade filogenética em relação às Hookeriales, ocasionando consequentemente o surgimento de diversas linhagens mal definidas morfologicamente que são extremamente semelhantes entre si geneticamente. Dessa maneira, nos clados apresentados para Hypnales existem muitas dúvidas em relação à correta organização das famílias, o que é representado pelos ramos filiais curtos. Assim, as relações entre os clados permanecem mal resolvidos (Huttunen et al. 2012).

Goffinet et al. (2009) e Shaw et al. (2003) reportam que Hypnales é composta mundialmente por 42 famílias, 408 gêneros e 4.400 espécies descritas. Hypnales é bem representada em áreas tropicais úmidas (Gradstein et al. 2001), e principalmente em altas altitudes (Buck 1998).

\section{Hypnaceae}

Dentro de Hypnales encontra-se entre outras a família Hypnaceae Schimp., que segundo Huttunen et al. (2012) e Cox et al. (2010) apresenta natureza ampla e consistentemente polifilética. Buck $(1998,2003)$ afirma que Hypnaceae é extremamente heterogênea (morfologicamente). Pode ser caracterizada por gametófitos pleurocárpicos, prostrados a ascendentes, filídios frequientemente falcados a lanceolados, espiralados a aplanados; pseudoparáfilos folhosos, triangular-lanceolados e filamentosos; margem dos filídios sem papila ou denticulada, presença de uma costa curta, dupla ou ausente, células laminares geralmente lineares, células alares diferenciadas; cápsulas geralmente inclinadas a assimétricas (Buck \& Goffinet 2000). O perístoma é bem desenvolvido com os dentes do exostômio estriados na face frontal (Buck 2003, Ireland \& Buck 2009). Esta família foi estabelecida por Schimper (1856), 
onde foram apresentados, entre outros, os gêneros Chryso-hypnum Hampe e Mittenothamnium Hennings, que aqui serão tratados.

Atualmente Hypnaceae compreende ca. de 40 gêneros e 1.000 espécies descritas. Essa família está entre os grupos taxonômicos mais diversificados dos musgos pleurocárpicos. A circunscrição familiar dentro de Hypnales, especialmente entre Hypnaceae e outras famílias, como Sematophyllaceae, Plagiotheciaceae e Amblystegiaceae, atualmente tem se tornado um assunto de interesse especial (Tsubota et al. 2002). Hypnaceae, segundo Nishimura et al. (1984), apresenta uma complexa história de mudanças, incluindo vários gêneros de outras famílias, tornando sua delimitação um trabalho difícil, visto que as espécies atualmente colocadas em Hypnaceae estão espalhadas em partes distantes da filogenia de Hypnales. Assim, qualquer estudo com o objetivo de esclarecer a delimitação familiar e taxonômica precisa incluir um número maior de espécies atráves do clado inteiro de Hypnales (Huttunen et al. 2012).

\section{Chryso-hypnum Hampe}

Das 16 espécies reportadas para o mundo (www.tropicos.org), por Hampe (1870), Willians (1921), Ochyra \& Sharp (1988), Higuchi (1986), Buck (1984, 1993, 1998) e Nishimura \& Ando (1986), cinco estão no Neotrópico, das quais a mais comum é Chryso-hypnum diminutivum (Hampe) W. R. Buck. No entanto, cerca de 12 espécies estão presentes no Paleotrópico (Gradstein et al. 2001) e uma nas Guianas (Florschützde Waard \& Veling 1996). Chryso-hypnum é um gênero de musgo pleurocárpico considerado um dos mais comum no Neotrópico (Gradstein et al. 2001), apresentando distribuição pantropical, com muitas espécies ocorrendo na África e América Latina (Sharp et al. 1994). Apesar dessa quantidade de espécie reportadas, alguns autores (Dr. Bruce Allen, comunicação pessoal e Gradstein et al. 2001) ressaltam que o número de espécies estão entre 5-10, surgindo assim a necessidade de se fazer uma revisão minuciosa e detalhada do gênero.

Chryso-hypnum é encontrado em altitudes que variam de 300-2600 m, podendo ocorrer em todos os substratos: solo, troncos vivos e em decomposição e rochas (Gradstein et al. 2001). Principalmente nas florestas mésicas, úmidas para florestas semi secas, em florestas de montanhas, especialmente em áreas abertas e florestas secundárias (Gradstein et al. 2001). 
Caracteriza-se pelo caulídio prostrado não estipitado, filídios ovaladolanceolados, costa dupla, curta; papilas em ambas as extremidades das células e pseudoparáfilo filamentoso e folhoso.

Estudos filogenéticos (Moura \& Câmara in. prep.) mostraram que Chrysohypnum é polifilético, aparecendo associado com Amblystegiaceae e Pylaisiaceae. Até o momento, os trabalhos publicados que descrevem esse gênero citam uma ampla variedade de características morfológicas que podem ser confundidas com outros gêneros da família Hypnaceae.

\section{Mittenothamnium Henn.}

Mittenothamnium apresenta ca. de 81 espécies aceitas (www.tropicos.org), com distribuição predominantemente Neotropical, com algumas poucas espécies ocorrendo na África. Entretanto, Gradstein et al. (2001) estimaram ca. de apenas 20 espécies para o gênero. Pode ser encontrado em altitudes que variam de 150-3400 m, podendo ocorrer em quase todos os substratos como troncos vivos, ramos, troncos em decomposição e pedras (Gradstein et al. 2001), em florestas de montanas, florestas abertas e em margens de florestas secundárias (Gradstein et al. 2001).

Mittenothamnium pode ser confundido com Chryso-hypnum, mas difere deste por apresentar caulídio estipitado, com os filídios do estipe diferindo dos filídios do caulídio e da ramificação, pseudoparáfilo triangular a triangular-lanceolado, folhoso e células com papilas apenas na porção superior (Buck 2003). Segundo este mesmo autor, Chryso-hypnum é uma segregação de Mittenothamnium.

Chryso-hypnum e Mittenothamnium são dois táxons que ainda não apresentam trabalhos taxonômicos específicos publicados, pois a circunscrição desses gêneros ainda é imprecisa e existem muitos problemas taxonômicos, como a falta de uma revisão completa dos grupos agregada a estudos filogenéticos.

Assim, configuram-se como objetivos deste estudo: 1) Realizar uma revisão taxonômica dos gêneros Chryso-hypnum e Mittenothamnium para o neotrópico, com elaboração de chave de identificação, ilustração, descrições das espécies através de estudo dos materiais tipos. 2) Revisar o número de espécies de cada um desses dois gêneros para o neotrópico. 3) Desenvolver um estudo filogenético usando marcadores moleculares para tentar estabelecer as relações dos dois gêneros de estudo. 4) Conhecer melhor a morfologia dos dois gêneros, explorando outros caracteres com base em dados 
morfológicos, através da morfologia das células proradas (papilas), esporos, com auxílio da microscopia eletrônica de varredura (MEV).

\section{Modelo de organização da tese}

De acordo com as diretrizes estabelecidas pelo Programa de Pós Graduação em Botânica / UnB e devido às facilidades deste modelo, optou-se pela apresentação da tese em um formato misto, dividida em formato clássico de tese e em artigos divididos em três capítulos, cada um correspondendo a uma publicação em revista cientifica:

\section{Capítulo 1 - Uma abordagem filogenética de Chryso-hypnum Hampe (Pylaisiaceae)} e Mittenothamnium Henning (Hypnaceae) usando os marcadores ITS, 26S e rps4. Visando confirmar o monofiletismo de Chryso-hypnum e Mittenothamnium e clarificar as relações filogenéticas de algumas espécies desses dois gêneros.

Capítulo 2 - Morfologia dos esporos e desenvolvimento das papilas (células proradas) nos filídios de Chryso-hypnum Hampe e Mittenothamnium Hennings

(Hypnaceae). Neste capítulo observam-se os resultados com os estudos de esporos e papilas nos filídios de Chryso-hypnum e Mittenothamnium apresentando mais duas diferenças morfológicas entre esses dois gêneros.

\section{Capítulo 3 - Revisão taxonômica de Mittenothamnium Hennings (Hypnaceae) para} o Neotrópico. Neste capítulo é apresentado o tratamento taxonômico para o gênero, incluindo chave de identificação, descrição, ilustração, sinonimizações, mapas de distribuição e status de conservação das espécies segundo os critérios da International Union for Conservation of Natures - IUCN.

\section{Capítulo 4 (Ainda em andamento):}

Revisão taxonômica de Chryso-hypnum Hampe (Pylaisiaceae) para o Neotrópico. (Moura \& Câmara in. prep.). Neste capítulo será apresentado o tratamento taxonômico para o gênero Chryso-hypnum, incluindo chave de identificação, descrição, ilustração, sinonimizações, mapas de distribuição e status de conservação das espécies segundo os critérios da International Union for Conservation of Natures - IUCN. 


\section{Referências Bibliográficas}

Ando, H. \& A. Matsuo. 1984. Applied Bryology. Advances in Bryology 2: 133-224

Buck, W. R. 1984. Taxonomic and nomenclatural notes on West Indian Hypnaceae. Brittonia. 36: 178-183.

Buck, W. R. 1993. Taxonomic Results of the Bryotrop Expedition to Zaire and Rwanda. Tropical Bryology 8: 199-217.

Buck, W. R. 1998. Pleurocarpous Mosses of West Indies. Memoirs of the New York Botanical Garden. 82: 1-400.

Buck, W. R. 2003. Guide to the Plants of Central French Guiana. Part 3. Mosses. Memoirs of the New York Botanical Garden. 76:1-167.

Buck, W. R. \& B. Goffinet. 2000. Morphology and Classification of Mosses. In: A.J. Shaw e B. Goffinet (eds.). Bryophyte Biology. University Press, Cambridge. 71-123.

Buck, W. R., C. J. Cox, A. J. Shaw, \& B. Goffinet. 2005. Ordinal relationships of pleurocarpous mosses, with special emphasis on the Hookeriales. Systematics and Biodiversity. 2: 121-45.

Cox, C. J., B. Goffinet, N. S. Wickett, S. Boles, \& J. Shaw. 2010. Moss diversity: A molecular phylogenetics analysis of genera. Phytotaxa. 9: 175-195.

Crandall-Stotler, B. \& R. R. E. Stotler. 2000. Morphology and classification of the Marchantiophyta. In: Shaw, A. J. \& Goffinet, B. Bryophyte Biology. Cambridge: University Press Cambridge, cap. 2, p. 21-70.

Cuming, A. C. 2009. Mosses as model organisms for developmental, cellular and molecular biology. Pp. 199-236. In: B. Goffinet \& A. J. Shaw (eds.), Bryophyte Biology. ed. 2. Cambridge University Press, Cambridge.

De Luna, E., A. E. Newton, A. Withey, D. Gonzalez, \& B. D. Mishler. 1999. The Transition to Pleurocarpy: A Phylogenetic Analysis of the Main Diplolepidous Lineages Based on rbcl Sequences and Morphology. The Bryologist. 102:634-650.

Fernández, E. G \& A. M. V. Serrano. 2009. Atividades Biológicas das Briófitas. Âmbito cultural, Rio de Janeiro.

Florschütz-de Waard, J. \& Veling, K. 1996. Flora of the Guianas. Royal Botanic Gardens, Kew. P. 439-461. 
Goffinet, B., \& W. R. Buck. 2004. Systematics of the Bryophyta (mosses): from molecules to a revised classification. Monographs in Systematic Botany from the Missouri Botanical Garden. 98:205-239.

Goffinet, B. \& A. J. Shaw. 2009. Bryophyte Biology. $2^{\text {nd }}$ edition. Cambridge University, Cambridge, Reino Unido. 119-120.

Goffinet, B., W. R. Buck. \& J. Shaw. 2009. Morphology and Classification of the Bryophyta. In: B. Goffinet and J. Shaw (Eds.). Bryophyte Biology. Cambridge University Press. 2: 55-138.

Gradstein, S. R., S. P. Churchill \& N. Salazar-Allen, 2001. Guide to the Bryophytes of Tropical America. Memoirs of the New York Botanical Garden. 86: 1-577.

Hampe, G. E. L. 1870. Videnskabelige Meddelelser fra Dansk Naturhistorisk Forening i Kjøbenhavn ser. 3, 2: 287.

Higuchi, M. 1986. Hikobia 9: 335.

Huttunen, S., N. Bell, V. K. Bobrova, V. Buchbender, W. R. Buck, C. J. Cox, B. Goffinet, L. Hedenäs, B. C. Ho, M. Ignatov, M. Krug, O. Kuznetsova, I. Milyutina, A. Newton, S. Olsson, L. Pokorny, A. J. Shaw, M. Stech, A. Troitsky, A. Vanderpoorten \& D. Quandt. 2012. Disentangling knots of rapid evolution: origin and diversification of the moss order Hypnales. Journal of Bryology. 34:187-202.

Ireland, R. R. \& W. R. Buck. 2009. Some Latin American Genera of Hypnaceae (Musci). Smithsonian contributions to Botany . 93:108.

La-Farge-England, C. 1996. Grouth form, branching pattern, and perichaetial position in mosses: cladocarpy and pleurocarpy redifined. The Bryologist 99:170-186.

Newton, A. E., C. J. Cox, J. G. Duckett, J. A. Wheeler, B. Goffinet, T. A. J. Hedderson \& B. D. Mishler. 2000. Evolution of the Major Moss Lineages: Phylogenetic Analyses Based on Multiple Gene Sequence and Morphology. The Bryologist. 103: 187-211.

Newton, A. E., N. Wikstrom, N. Bell, L. L. Forrest \& M. S. Ignatov. 2007. Dating the Diversification of the Pleurocarpous Mosses. In: A. E. Newton and R. S. Tangney (Eds.). Pleurocarpous Mosses - Systematics and Evolution. Boca Raton: CRC Press. 337-366.

Nishimura, N. \& H. Ando. 1986. A Revision of Some Mittenothamnium Species Described from Mexico. The Bryologist. 89: 66-69. 
Nishimura, N., M. Higuchi, T. Seki \& H. Ando. 1984. Delimitation and subdivision of the moss family Hypnaceae. Journal of the Hattori Botanical Laboratory. 55: 227234.

Ochyra, R. \& Sharp, A. J. 1988. Journal of the Hattori Botanical Laboratory 65: 370.

Qiu, Y.-L., L. Li, B. Wang, Z. Chen, V. Knoop, M. Groth-Malonek, O. Dombrovska, J. Lee, L. Kent, J. Rest, G. F. Estabrook, T. A. Hendry, D. W. Taylor, C. M. 10 Testa, M. Ambros, B. Crandall-Stotler, R. J. Duff, M. Stech, W. Frey, D. Quandt \& C. C. Davis. 2006. The deepest divergences in land plants inferred from phylogenomic evidence. Proc. Natl. Acad. Sci. U.S.A. 103: 15511-15516.

Sharp, A. J., H. A. Crum \& P. Eckel. 1994. The Moss Flora of Mexico. Memoirs of The New York Botanical Garden. 69: 1-1113.

Shaw, A. J., C. J. Cox., B. Goffinet, W. R. Buck \& S. B. Boles. 2003. Phylogenetics evidence of a rapid radiation of Pleurocarpous mosses (Bryophyta). Evolution. 57: 2226-2241.

Tropicos.org. Missouri Botanical Garden. 2016. http://www.tropicos.org

Tsubota, H.; Arikawa, T.; Arikawa, H.; De Luna, E.; Gonzales, D.; Higuchi. M. \& Deguchi, H. 2002. Molecular Phylogeny of hypnobryalean mosses as inferred from a large-scale dataset of chloroplast rbcL, with special reference to the Hypnaceae and possibly related families. Hikobia 13: 645-665.

Zartman, C. E. 2003. Habitat fragmentation impacts on epiphyllous bryophyte communities in central Amazonia. Ecology 84 (4): 949-954.

Welch, W. H. 1948. Mosses and their uses. Procedings Indiana Academy of Science 58: $31-46$.

Willians, R. S. 1921. Report of the Canadian Arctic Expedition 1913-18 4(E): 10-11, f. $13-18$. 


\title{
CAPÍTULO 1
}

A ser submetido para a revista Systematic Botany

\section{Uma abordagem filogenética de Chryso- hypnum Hampe (Pylaisiaceae) e Mittenothamnium Hennings (Hypnaceae) usando os marcadores ITS, 26S e rps4}

\author{
Osvanda Silva de Moura ${ }^{1}$ \& Paulo Eduardo A. S. Câmara ${ }^{1}$ \\ ${ }^{1}$ Universidade de Brasília, Depto de Botânica. Campus Universitário Darcy Ribeiro, \\ Asa Norte, Brasília, DF. Brasília 70910-970. \\ ${ }^{1}$ Autor para correspondência (osvanda@ hotmail.com)
}

Resumo - Chryso-hypnum Hampe é composto por cerca de 16 espécies, cuja morfologia é bastante confusa por falta de delimitação de características exclusivas para o gênero. Mittenothamnium Henn. apresenta cerca de 81 espécies descritas. Esse gênero também apresenta uma morfologia bastante confusa, com muitos sinônimos ao redor de Mittenothamnium reptans, justamente por não apresentar uma delimitação completa das características exclusivas para o gênero. $\mathrm{O}$ objetivo deste estudo foi esclarecer através de filogenia molecular a posição familiar dos gêneros Chryso-hypnum e Mittenothamnium, e apontar possíveis sinapomorfias para Chryso-hypnum $e$ Mittenothamnium. Foram feitas análises de máxima parcimônia, máxima verossimilhança e inferência bayesiana utilizando os marcadores moleculares $r p s 4,26 \mathrm{~S}$ e ITS. As reconstruções mostraram três core monofilético que foram reconhecidos como: gênero Pseudochryso-hypnum (nome informal), gênero Chryso-hypnum e gênero Mittenothamnium. A filogenia apontou um clado estabelecido dentro de Pseudochrysohypnum, três subclados dentro de Chryso-hypnum e dois subclados estabelecidos em Mittenothamnium, todos com espécies bem delimitadas para a região neotropical.

Palavras-chaves: Bryophyta, Filogenia Molecular, Musgos, Hypnaceae, Pylaisiaceae. 
Abstract - Chryso-hypnum Hampe is composed of about 16 species, the morphology of which is quite disorderly due to the lack of delimitation of unique characteristics the genus. Mittenothamnium Henn. presents around 81 described species. This genus also presents a rather chaotic morphological delimitation, with many synonyms for Mittenothamnium reptans, precisely because there is not a complete definition of the characteristics unique to the genus. The objective of this study was to clarify, through the use of molecular phylogeny, the familiar position of each of the genera Chrysohypnum and Mittenothamnium, and to point out possible synapomorphy for each genus. Maximum parsimony, maximum likelihood and bayesian inference analysis were performed using the molecular markers $r p s 4,26 \mathrm{~S}$ and ITS. The reconstructions showed three monophyletic cores that were recognized as: the genus Pseudochryso-hypnum (informal name), the genus Chryso-hypnum and the genus Mittenothamnium. The phylogeny indicates a clade established within Pseudochryso-hypnum, three subclade within Chryso-hypnum and two subclades established within Mittenothamnium, all with species well defined for the Neotropical region.

Keywords: Bryophyta, Molecular phylogeny, Mosses, Hypnaceae, Pylaisiaceae. 


\section{Introdução}

Os musgos pleurocárpicos são um grupo monofilético (Cox et al. 2010; De Luna et al. 1999; Huttunen et al. 2012; Newton et al. 2000), que constituem uma linhagem altamente diversificada com aproximadamente 42\% das 12.000 espécies de musgos (Newton et al. 2007), sendo representados por três ordens: Hookeriales, Ptychomniales e Hypnales (Goffinet et al. 2009, Newton et al. 2007). A radiação dos pleurocárpicos é datada em aproximadamente 165-131 milhões de anos, coincidindo com o aparecimento das complexas florestas de angiospermas no Cretáceo (Newton et al. 2007), sendo, portanto, um grupo altamente derivado.

Hypnales é detentora de $80 \%$ das espécies de musgos pleurocárpicos apresentando-se como uma das maiores e mais diversificadas ordens em número de espécies da divisão Bryophyta (Goffinet and Buck 2004) com aproximadamente 4.400 espécies (Goffinet et al. 2009). Possui seu centro de diversidade em áreas tropicais (Buck 1998), com seus representantes ocorrendo principalmente em áreas florestais.

Shaw et al. (2003) concluíram que Hypnales apresenta evidência de uma rápida diversificação nos primeiros $20 \%$ de sua história evolutiva, provocando uma menor diversidade filogenética em relação aos outros grupos, como Hookeriales (seu grupo irmão), ocasionando consequentemente o surgimento de diversas linhagens mal definidas morfologicamente, que são extremamente semelhantes entre si geneticamente, e a presença de muitos ramos internos curtos (Shaw et al. 2003). Assim, nos clados apresentados para Hypnales há muitas dúvidas em relação ao posicionamento das famílias (Huttunen et al. 2012).

Apesar de Hypnales ser monofilética (Shaw et al. 2003), pouco se sabe das relações entre os grupos, pois apenas algumas famílias como Amblystegiaceae, Brachytheciaceae, Hylocomiaceae, Sematophyllaceae, Plagiotheciaceae, Pylaisiaceae e Pylaisiadelphaceae foram estudas e apresentaram-se como um grupo monofilético bem resolvido (Chiang and Schaal 2000, Gardiner et al. 2005, Huttunen et al. 2012, Pedersen and Hedenäs 2002, Tsubota et al. 2001a e b, Vanderpoorten et al. 2005).

A família Hypnaceae pertence à ordem Hypnales, compreendendo mundialmente cerca de 40 gêneros, e 1.000 espécies descritas. No neotrópico ocorrem 21 gêneros e cerca de 70 espécies (Gradstein et al. 2001). Hypnaceae tem sido considerada um grupo heterogêneo e genérico com gêneros mal definidos (Hedenäs 1989), com alta diversidade de espécies, sendo considerada consistentemente 
polifilética (Arikawa and Higuchi 1999; Tsubota et al. 1999; Buck et al. 2000; Arikawa and Higuchi 2003; Gardiner et al. 2005; Cox et al. 2010; Huttunen et al. 2012). Vitt (1982) já duvidava que a circunscrição de Hypnaceae resistiria a um exame crítico: uma conjectura que foi corroborada com os trabalhos citados acima.

Apesar de ser uma das maiores famílias dentro de Hypnales (Gradstein et al. 2001), estudos filogenéticos de Gardiner et al. (2005), Arikawa et al. (2008), Cox et al. (2010) e Huttunen et al. (2012), mostraram que apenas dois táxons pertencem a Hypnaceae: Hypnum cupressiforme (espécie tipo da família) e Eurohypnum leptothallum (Arikawa et al. 2008; Cox et al. 2010; Gardiner et al. 2005; Huttunen et al. 2012). Dessa maneira, muitos gêneros tradicionalmente associados à Hypnaceae acabaram permanecendo sem família ou em posição famíliar incerta. Entre eles estão Chryso-hypnum Hampe e Mittenothamnium Henning, que ainda estão inseridos em Hypnaceae.

Mittenothamnium possui várias semelhanças com Chryso-hypnum, como filídios do caulídio com região alar desenvolvida ou diferenciada, base não decurrente ou inconspicuamente decurrente, filídios do caulídio lanceolados, ovalado-lanceolados ou ovalados e filídios dos ramos frequentemente complanados (Buck 1998; Sharp et al. 1994). No entanto, diferencia-se de Chryso-hypnum por apresentar caulídio estipitado, pseudoparáfilo folhoso, triangular ou triangular-lanceolado e filídios projetando papilas apenas no ápice da célula. Alguns trabalhos, por exemplo, como de Britton (1914), mostram que Chryso-hypnum já foi sinônimo de Mittenothamnium.

Trabalhos que envolvem Chryso-hypnum (Buck 1998, Buck 2003, Gradstein et al., 2001, Sharp et al. 1994, Florschütz-De Waard and Veling 1996, entre outros) esclarecem algumas características morfológicas para o gênero, como caulídio não estipitado (característica essa que o separa de Mittenothamnium, citada acima); pseudoparáfilo filamentoso ou folhoso; filídios do caulídio e ramos similares; costa curta e dupla; célula linear, com papilas em ambas as extremidades. Além disso, existe uma grande semelhança morfológica entre quase todas as espécies aceitas

Chryso-hypnum foi descrito originalmente por Georg Ernst Ludwig Hampe (1870), como um subgênero de Hypnum. Atualmente, Chryso-hypnum compreende cerca de 12-16 espécies reportadas (www.tropicos.org, Buck 2014) para o mundo. Mas Gradstein et al. (2001) afirmam que ocorra cerca de cinco a 10 espécies. É um gênero de musgo pleurocárpico considerado um dos mais comuns no Neotrópico (Gradstein et 
al. 2001), apresentando distribuição pantropical, com espécies ocorrendo na África, Américas (Sharp et al. 1994), e associadas a ilhas (Gradstein et al. 2001).

Já Mittenothamnium foi descrito pela primeira vez por Paul Christoph Hennings (1902). Atualmente, é um gênero que apresenta cerca de 80 espécies reportadas para o mundo (Gradstein et al. 2001, www.tropicos.org). Porém, Gradstein et al. (2001) acreditam que a estimativa mais realística seja de 10-20 espécies. Mittenothamnium é um gênero de musgo pleurocárpico, ocorrendo principalmente no neotrópico, com alguns táxons ocorrendo na África e associados à ilhas (Gradstein et al. 2001).

As espécies de Chryso-hypnum e Mittenothamnium sempre estiveram agrupadas e inseridas somente em uma família ao longo da história, Hypnaceae (Fleischer 1908; Brotherus 1925; Buck and Goffinet 2000; Goffinet and Shaw 2009). Mesmo com a posição dentro de Hypnaceae, algumas espécies já foram inseridas e retiradas desses dois gêneros (Buck 1984; Nishimura and Ando 1986), mas essas mudanças foram baseadas em características morfológicas.

Apesar de morfologicamente conhecidos, Chryso-hypnum e Mittenothamnium carecem de abordagens filogenéticas consistentes. Os dois únicos estudos que incluiram estes gêneros (Cox et al. 2010, Huttunen et al. 2012) o fizeream em um contexto de uma abordagem ampla com o objetivo de inserir representantes de várias famílias para inferências filogenéticas de categorias maiores. Assim, mesmo a família sendo polifilética é importante notar que a própria relação interna dos gêneros inseridos atualmente em Hypnaceae não é clara, tendo em vista que nenhuma análise mais abrangente e completa para o grupo foi realizada até o momento, muito menos para Chryso-hypnum e Mittenothamnium.

Dessa maneira, configuram-se objetivos deste trabalho: 1) Testar se os gêneros Chryso-hypnum e Mittenothamnium são monofiléticos; 2) Esclarecer a posição familiar de Chryso-hypnum e Mittenothamnium e 3) fornecer subsídios para uma revisão taxonômica clássica para esses dois gêneros.

\section{Material e Métodos}

Identificação e Amostragem. Para maior confiabilidade dos resultados, todas as amostras seqüenciadas neste estudo (Tabela 1) foram devidamente identificadas utilizando chaves de identificação e literatura especializada (Buck 1998, Sharp et al. 
1994, entre outros), além da observação e descrição do tipo nomenclatural de cada espécie.

Foram incluídos nas análises o total de 29 espécimes dos dois gêneros estudados, Chryso-hypnum e Mittenothamnium, com as seguintes espécies: Chryso-hypnum cavifolium (Dixon) Ochyra and Sharp, C. diminutivum (Hampe) W. R. Buck, $C$. elegantulum (Hook.) Hampe, C. reduncum (Ochyra) Moura Comb. nov, $C$. squarrosulum (Card.) Nishimura and Ando, Chryso-hypnum sp1., Mittenothamnium loriforme (Hampe) Card., M. reptans (Hedw.) Card., M. scalpellifolium (Müll. Hal.) H. A. Crum, M. substriatum (Mitt.) Card., Mittenothamnium sp1 e Mittenothamnium sp2. Todos os 29 espécimes são provenientes de diferentes regiões da América Latina, América do Norte, América Central e África (Tabela 1). Esses espécimes foram selecionados para refletirem a variação morfológica e geográfica do grupo. Do Genbank foram utilizadas 92 seqüencias (Tabela 2) das espécies inclusas em Hypnales observadas no trabalho de Cox et al. (2010) e Huttunen et al. (2012).

Para reconstrução filogenética foram selecionados três marcadores moleculares (Tabela 3): ribossomal protein 4 (rps4, plastidial) (Nadot et al. 1994), $26 S$ ribossomal RNA (26S, nuclear) (Cox et al. 2004) e ITS1-ITS2 region (ITS, nuclear) (White et al. 1990). O uso de diferentes marcadores de diferentes compartimentos é recomendável, uma vez que estes não estão sujeitos às mesmas pressões seletivas, sendo assim os agrupamentos formados irão refletir melhor a evolução dos organismos como um todo e não apenas de uma única porção gênica. A seleção destes marcadores foi baseada no trabalho de Cox et al. (2010) e Huttunen et al. (2012). A escolha do grupo externo foi baseada em Huttunen et al. (2012).

Extração e amplificação. O procedimento de extração foi realizado no Laboratório de Biologia Molecular do Departamento de Botânica da Universidade de Brasília (UnB), utilizando amostras frescas ou material herborizado quando disponível e viável, seguindo o protocolo mini-CTAB proposto por Doyle and Doyle (1987), com as adaptações descritas por Câmara (2009).

Para a amplificação das regiões desejadas de DNA foi empregada a técnica de reação em cadeia da polimerase (PCR). Para o mix de amplificação usou-se $50 \mu \mathrm{L}$, contendo por amostra $5 \mu \mathrm{L}$ a $5 \mathrm{X}$ de Buffer termofilico sem $\mathrm{Mg}, 5 \mu \mathrm{L}$ a $50 \mathrm{mM} \mathrm{de} \mathrm{MgCl}_{2}$, $0,5 \mu \mathrm{L}$ de Taq (Phoneutra), $2 \mu \mathrm{L}$ a $10 \mathrm{mg} / \mathrm{ml}$ de BSA (Phoneutra,), $4 \mu \mathrm{L}$ a $1 \mathrm{mM}$ de dNTP, 
2,5 $\mu \mathrm{L}$ (1:9) de cada primer (Forward e Reverse) e $2 \mu \mathrm{L}$ de DNA amostrado, completados com 26,5 $\mu \mathrm{L}$ de água Milli-q. O ciclo utilizado para a amplificação dos marcadores $r p s 4, I T S$ e $26 S$ foi: $95^{\circ} \mathrm{C}(1 \mathrm{~min}), 50-54^{\circ} \mathrm{C}(1 \mathrm{~min})$ e $72^{\circ} \mathrm{C}(1 \mathrm{~min})$ por 35 ciclos, sempre precedido por uma desnaturação inicial de 1 minuto a $95^{\circ} \mathrm{C}$; alongamento final a $72^{\circ} \mathrm{C}$ por 7 minutos. Quando necessário, a PCR foi otimizada com o uso da betaína ou DMSO. O produto da PCR foi encaminhado para purificação e sequenciamento na Macrogen Inc. (Seoul, South Korea).

Edição dos dados $\boldsymbol{e}$ alinhamentos. Para cada táxon seqüenciado foram adquiridas as sequências "forward" e "reverse". A seqüência consenso (contig) foi obtida com o software Codon Code Aligner versão 4.1. e o alinhamento das sequências foi realizado no Clustal X v.2.0 (Larkin et al. 2007). Os ajustes manuais foram feitos através do software PHYDE v.0.9971. (Müller et al. 2006), quando necessários, conforme Buck et al. (2005). Dados do INDEL (inserções e deleção) foram incluídos nas matrizes utilizando o software SeqState (Müller 2005) através do método Simple indel coding (Simmons and Ochoterena 2000).

Análises filogenéticas. Foram feitas análises independentes para cada marcador e também com os três marcadores combinados $(26 S+r p s 4+I T S)$. Foram empregadas análises de máxima parcimônia (MP), máxima verossimilhança (ML) e Inferência Bayesiana (BI).

As análises de MP foram feitas através do software PAUP v.4.09131 (Swofford 2002), por busca heurística e tree-bisection reconnection (TBR) branch swapping, com 10.000 árvores geradas. Todos os caracteres foram igualmente ponderados.

As análises de ML foram feitas através do software RaxML 8.0.0 (Stamatakis 2014). A topologia gerada foi visualizada no software FigTree v. 1.4.2 (Rambaut 2012).

Inferências bayesianas foram realizadas utilizando o Mr.Bayes v.3.2.6 (Ronquist and Huelsenbeck 2015) através do Cipres Science Gateway - Cyberinfrastructure for Phylogenic Research (Miller et al., 2010). Foram processadas em quatro cadeias de Markov Monte Carlo (MCMC), cada uma com 5.000.000 de gerações, amostradas a cada 1.000 gerações e em duas corridas paralelas. A convergência foi estabelecida garantindo que o desvio padrão da média da freqüência de separação (split frequencies) foi menor que 0,02. O software Tracer 1.5 (Rambaut and Drummond 2013) foi utilizado 
para verificar a convergência, ou seja, para determinar quando a amostragem das árvores estava estabilizada. Os primeiros $25 \%$ das árvores foram descartadas "burn-in". A árvore consenso (Majority rule) foi construída a partir das árvores resultantes para estimar as probabilidades posteriores. A visualização da árvore gerada e das probabilidades posteriores foram feitas utilizando o software FigTree versão 1.4.2 (Rambaut 2012).

O suporte para os nós foi obtido através do bootstrap não paramétrico para MP e ML (Felsenstein 1985), com 1.000 replicações, e de probabilidades posteriores para BI. Valores de boostratp foram considerados baixos quando menores que 70 , moderados e aceitáveis de 70 a 80 , altos quando maior que 80 e máximo quando igual 100. Os valores para probabilidades posteriores variam de 0 e 1 , sendo que valores abaixo de 0,90 foram considerados não confiáveis, altos acima de 0,95 e máximo quando igual a 1.

Os modelos de substituição de nucleotídeos utilizados nas análises de ML e BI foram estimados através do software JmodelTest v.2 (Darriba et al. 2012; Guindon and Gascuel 2003) com base no método de "Akaike information criterion" (AIC, Akaike 1973), e os melhores modelos encontrados estão na Tabela 4.

Shimodaira-Hasegawa teste. Foi realizado o teste SH para comparar estatisticamente hipóteses alternativas a respeito do monofiletismo de grupos específicos. As árvores de restrição (constraint trees) foram desenhadas no Mesquite v. 3.04 (Maddison and Maddison 2015). O teste foi executado no PAUP* v.4.09131 (Swofford 2002), através de análise de verossimilhança. Os escores da árvore original e da restrição foram comparados usando 1.000 replicações através do método RELL (resampling estimated log likelihood).

\section{Resultados}

Análise filogenética. Para as análises filogenéticas foram produzidas 43 novas sequências (22 de ITS, 10 de $26 \mathrm{~S}$ e 11 de rps4 - Tab. 1) e 92 acessos foram retirados do Genbank (Tabela 2) dentre todos os marcadores utilizados. (Tabela 3).

Todas as árvores obtidas individualmente para cada marcador apresentaram topologias diferentes, pois nem todas as sequências de $26 \mathrm{~S}$ e rps4 foram amplificadas. 
Assim, as reconstruções individuais de cada marcador apontaram conflitos entre as topologias, diferindo no grau de resolução dos nós. Logo, as matrizes não foram concatenadas. A melhor hipótese de história evolutiva obtida foi utilizando o marcador individual ITS, pois apresentou melhor suporte para os ramos. Dessa maneira, toda a discussão neste trabalho será focada na topologia gerada a partir de análises utilizando essa matriz (Figura 1). A estatística das árvores está apresentada na tabela 4.

Em todas as análises Chryso-hypnum é resolvido como polifilético, com a formação de dois clados (I e II) monofiléticos (Fig. 1), distantes um do outro, bem definidos e divididos da seguinte forma:

Clado I. Informalmente denominado de Pseudochryso-hypnum. Este clado apresentou suporte máximo em BI ( $\mathrm{PP}=1)$, mas sem suporte em ML e em MP (Figura 2). É composto por quatro espécimes de Chryso-hypnum: C. diminutivuml proveniente do Caribe, $C$ diminutivum2 do Brasil (Pará), $C$. squarrosulum do Suriname e $C$. reduncum do Brasil (RS) (Figura 2). Dentro desse clado formou-se um subclado, A, monofilético composto por dois espécimes de Chryso-hypnum diminutivum (1 e 2). Esse clado apresentou-se dentro de Amblystegiaceae e longe dos outros espécimes de Chryso-hypnum (Clado II).

Clado II. "core" Chryso-hypnum. Este clado possui suporte máximo em análises de $\mathrm{BI}$ e ML ( $\mathrm{PP}=1, \mathrm{BS}=100)$ e suporte alto em MP (BS=99). É composto por nove espécimes (Figura 3), sendo quatro representantes de Chryso-hypnum elegantulum oriundos do Brasil: (1) Goiás, (2 e 3) Distrito Federal e (4) Espírito Santo; três representantes de Chryso-hypnum diminutivum, também oriundos dos Brasil: (1 e 2) Distrito Federal, (3) Mato Grosso; um Chryso-hypnum sp1. da Nicarágua e um representante de Chryso-hypnum cavifolium, oriundo da África . Dentro deste clado foram formados três subclados, A, B e C, monofiléticos bem definidos. O subclado A compreende os três espécimes de Chryso-hypnum elegantulum (1, 2 e 3), e apresentou suporte baixo em BI $(\mathrm{PP}=0,76)$ em ML $(\mathrm{BS}=64)$ e em MP $(\mathrm{BS}=68)$. O outro espécime de C. elegantulum (4) apareceu suportado como grupo irmão das outras C. elegantulum com suporte máximo em BI (PP=1), e bootstrap (BS) iguais a 95 e 95 (ML e MP, respectivamente). O subclado B é composto por três espécimes de Chryso-hypnum diminutivum (1, 2 e 3), apresentando suporte baixo em $\mathrm{BI}(\mathrm{PP}=0,8)$ e bootstrap (BS) alto 
iguais a 95 e 92 (ML e MP, respectivamente). E o subclado C é formado por dois espécimes: $C$. cavifolium e $C$. sp1., apresentaram suporte máximo para $\mathrm{BI}(\mathrm{PP}=1)$ e alto para MP (BS=99), mas, suporte baixo para ML $(\mathrm{BS}=69)$. Esse “core” apresentou-se como grupo irmão de Pylaisiaceae.

Clado III. “core"Mittenothamnium. Este clado possui suporte máximo em análises de $\mathrm{BI}(\mathrm{PP}=1)$, alto em ML $(\mathrm{BS}=97)$ e suporte moderado em MP $(\mathrm{BS}=75)$. É composto por oito espécimes (Figura 3), sendo quatros representantes de Mittenothamnium reptans, oriundos da Guatemala (1), Costa Rica (2), México (3) e Bolívia (4); M. scalpellifolium representante da Nicarágua; M. substriatum da Bolívia; Mittenothamnium sp1, do México e Mittenothamnium sp2 da Bolívia. Dentro deste clado foram estabelecidos dois subclados, A e B, monofiléticos. Subclado A compreende dois espécimes: $M$. reptans (1) e M. reptans (2), e apresentou suporte alto para $\mathrm{BI}(\mathrm{PP}=0,97)$, moderado para $\mathrm{ML}(\mathrm{BS}=73)$ e alto para $\mathrm{MP}(\mathrm{BS}=98)$. O Subclado $\mathrm{B}$ compreende dois espécimes: M. substriatum e Mittenothamnium sp. 2 com suporte baixo em $\mathrm{BI}(\mathrm{PP}=0,80)$, moderado em $\mathrm{ML}(\mathrm{BS}=72)$, e baixo em MP $(\mathrm{BS}=57)$. Este clado apresentou-se como grupo irmão de Hypnaceae, porém, sem suporte.

O espécime $M$. reptans (4) apareceu como grupo irmão dos espécimes $M$. substriatum e Mittenothamnium sp2, com suporte máximo em $\mathrm{BI}(\mathrm{PP}=1)$, moderado para ML $(\mathrm{BS}=70)$ e baixo para MP $(\mathrm{BS}=54)$. Já M. reptans (3), apareceu como grupo irmão de todos os espécimes citados acima, com suporte máximo em BI ( $\mathrm{PP}=1)$, moderado em ML (BS=71) e baixo em MP $(\mathrm{BS}=55)$.

O espécime Mittenothamnium sp1, se apresentou como grupo irmão dos dois subclados citados anteriormente, com suporte alto em BI $(\mathrm{PP}=0,92)$, baixos em ML (BS=60) e MP (BS=64). E M. scalpellifolium apareceu como grupo irmão de Mittenothamnium sp1, com suporte alto em BI $(\mathrm{PP}=1)$ e ML $(\mathrm{BS}=97)$ e moderado para $\mathrm{MP}(\mathrm{BS}=75)$.

No entanto, o espécime Mittenothamnium loriforme apareceu sem suporte (politomia) fora do core de Mittenothamnium.

\section{Resultados do Teste SH:}


Foram feitos testes $\mathrm{SH}$, a fim de testar hipóteses alternativas a respeito do monofiletismo dos clados I e III:

Clado I. Resultados do teste SH (Árvore de restrição - Figura 4) evidenciaram que esse clado não é grupo irmão dos demais Chryso-hypnum, sendo estatisticamente menos significativo $(\mathrm{p}<0,05)$.

Clado III. Resultados do teste SH (Fig. 5) evidenciaram que M. loriforme é grupo irmão de todos os outros espécimes de Mittenothamnium (p>0,05) não rejeitando, assim, o monofiletismo. 


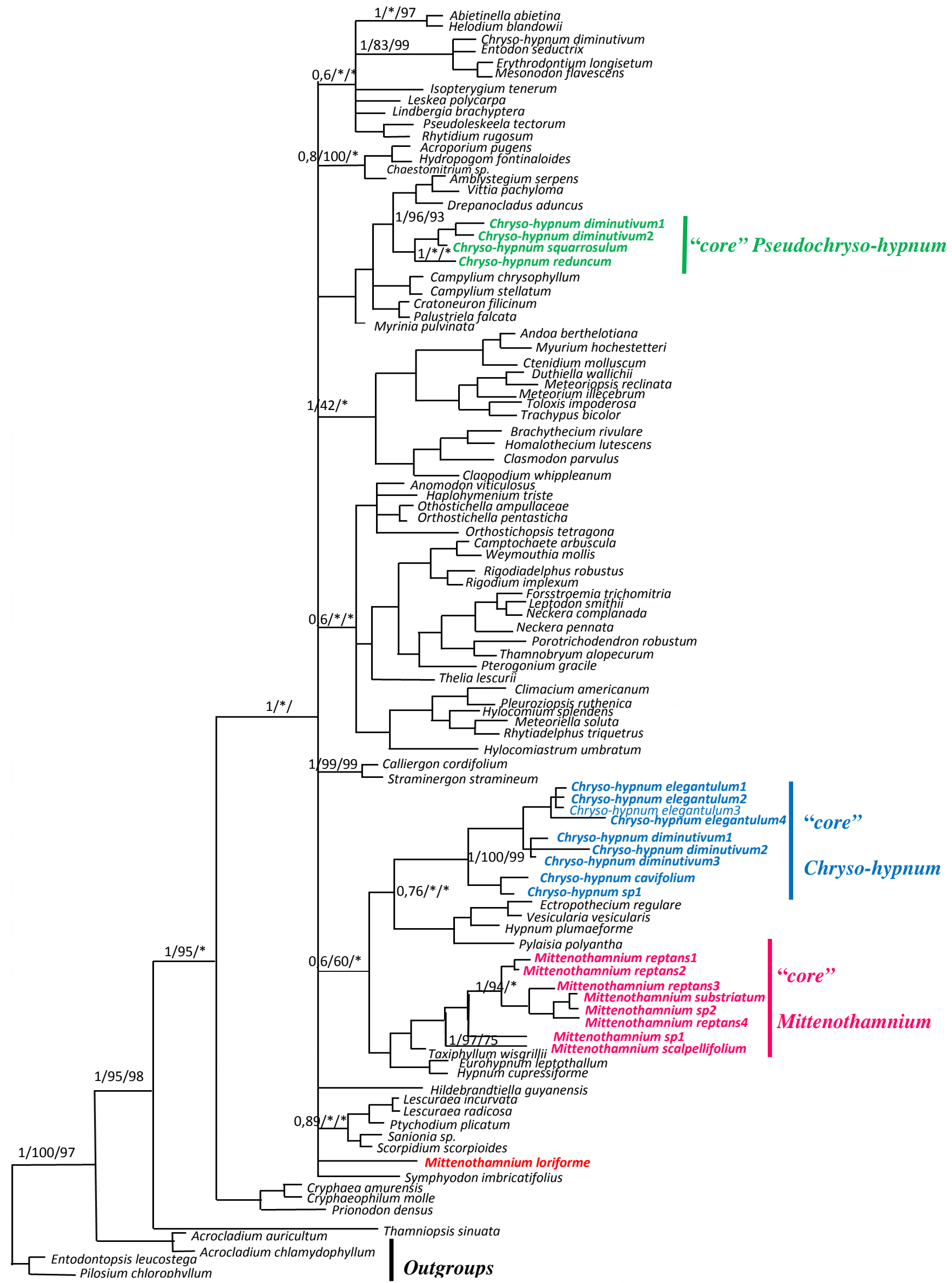

Figura 1. Filograma gerado por inferência bayesiana a partir da matriz individual do marcador ITS. Valores nos ramos correspondem aos valores de probabilidades posteriores da análise de Bayesiana (PP), bootstrap de verossimilhança BS (ML) e parcimônia BS (MP), respectivamente. ${ }^{*}$ Sem suporte. 


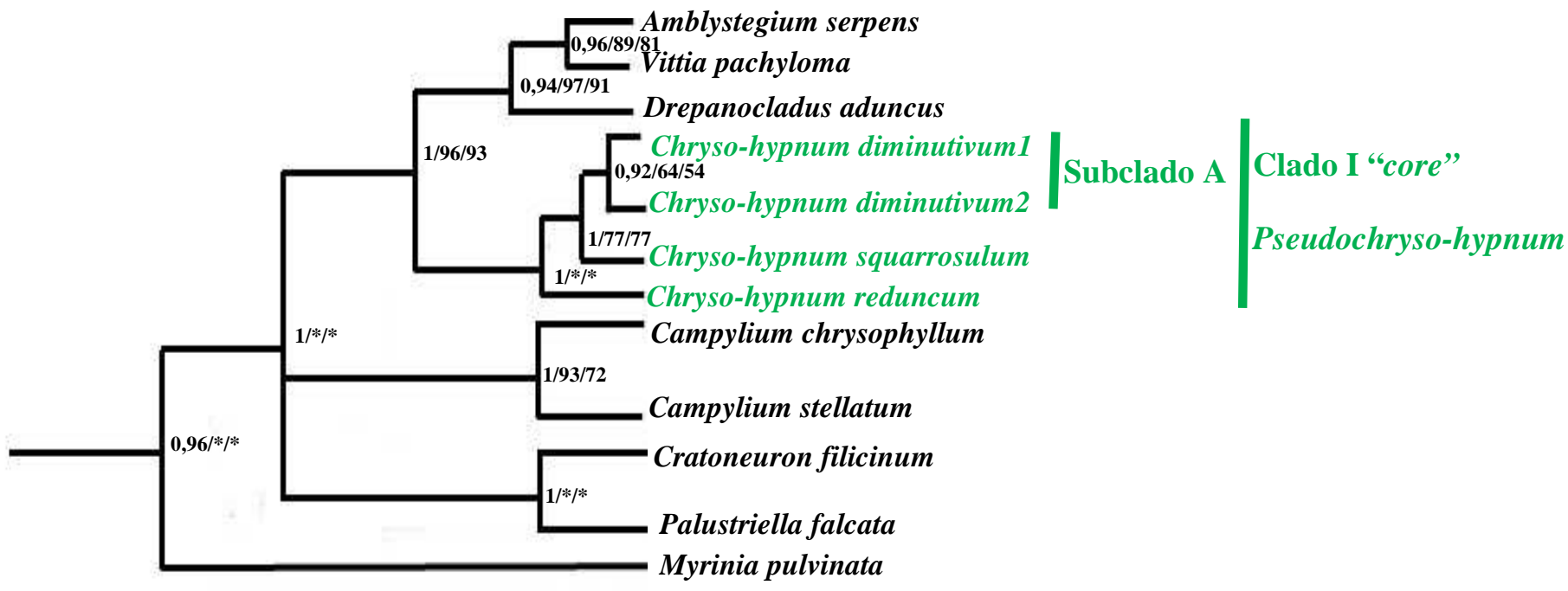

Figura 2. Destaque para clado I, "core" Pseudochryso-hypnum, apresentado na Figura 1. Valores nos ramos correspondem aos valores de probabilidades posteriores da análise de Bayesiana (PP), bootstrap de verossimilhança BS (ML) e parcimônia BS (MP), respectivamente. ${ }^{*}$ Sem suporte. 
A

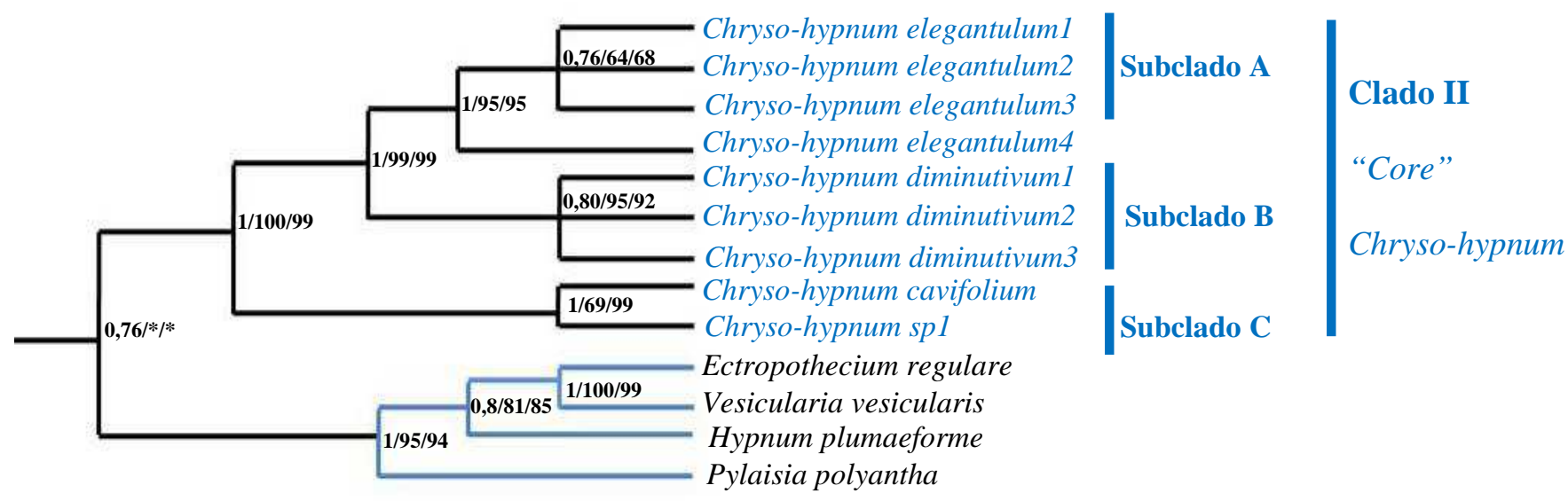

B

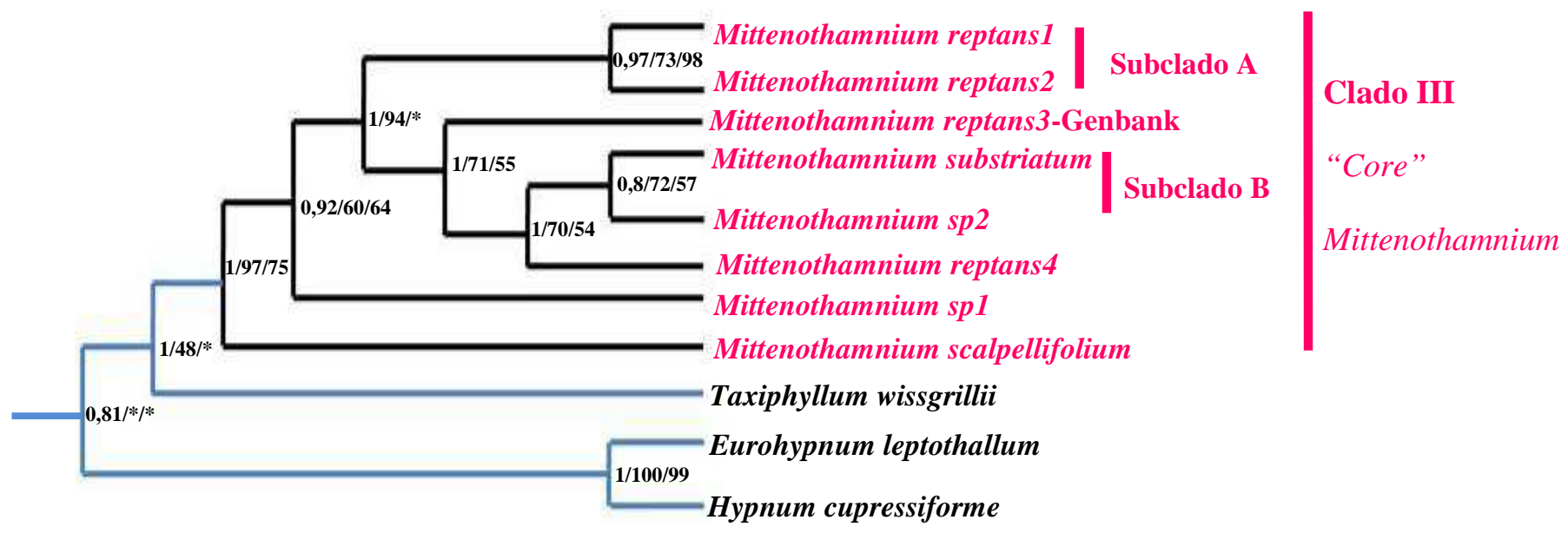

Figura 3. Destaque para clado "core" Chryso-hypnum (A) e "core" Mittenothamnium (B), apresentados na Figura 1. Valores nos ramos correspondem aos valores de probabilidades posteriores da análise de Bayesiana (PP), bootstrap de verossimilhança BS (ML) e parcimônia BS (MP), respectivamente. * Sem suporte. (Taxiphyllum wissgrillii: grupo irmão do "core"Mittenothamnium). 


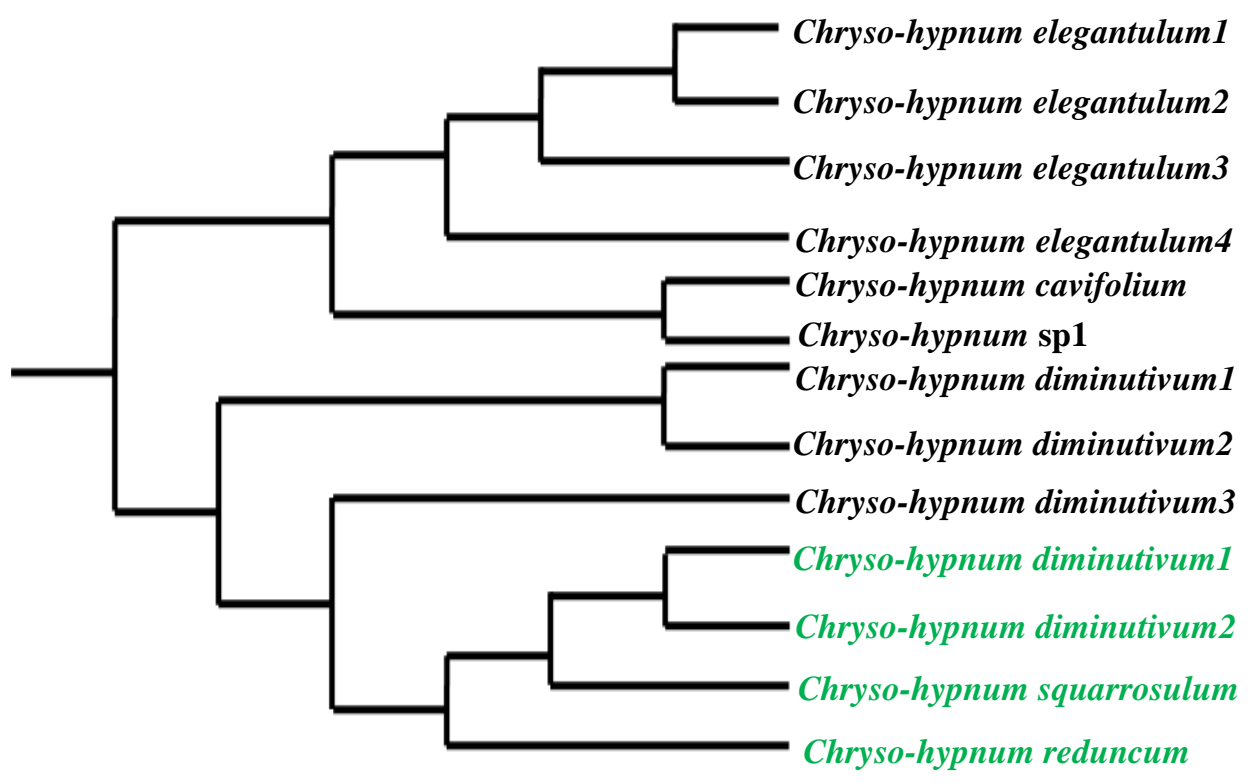

Figura 4. Árvore de restrição com os quatro espécimes do "core” Pseudochrysohypnum (verde), com $\mathrm{p}<0,05$, resultante do teste $\mathrm{SH}$, rejeitando-se, portanto o monofiletismo de Chryso-hypnum.

A

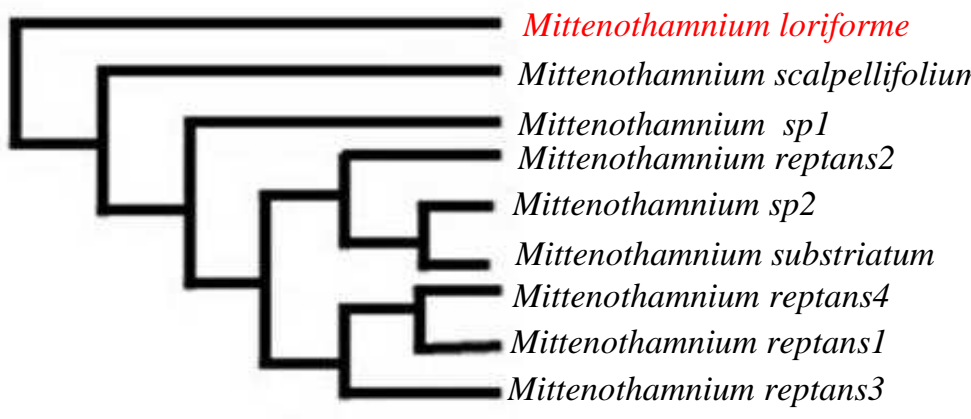

B

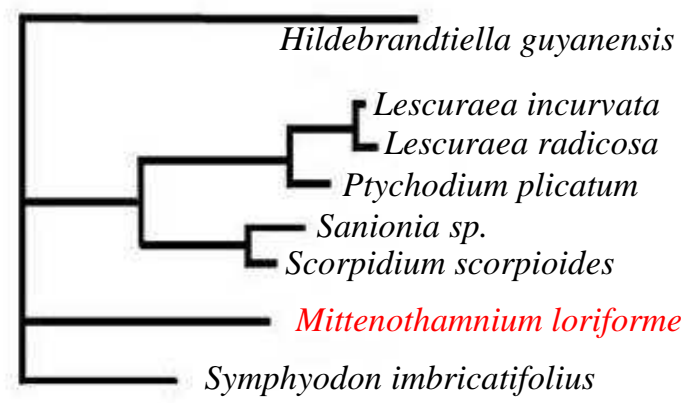

Figura 5. A. Árvore de restrição do clado III, com $p>0,05$, resultante do teste $\mathrm{SH}$, não rejeitando o monofiletismo do gênero. B. Topologia original. 


\section{Discussão}

Sequiência de DNA. Marcadores de cloroplasto são os mais amplamente utilizados para reconstrução filogenética de briófitas. No entanto, há também os marcadores nucleares que incluem, principalmente, aqueles do complexo ribossomal (18S, 5.8S, 26S, ITSI e ITSII), os quais apresentam seu próprio padrão de evolução (Câmara and Shaw 2013). Assim, nesse estudo, o marcador ITS mostrou-se bastante promissor, uma vez que este marcador individual também tem proporcionado bom suporte para maioria dos grupos (Shaw et al. 2003).

Monofiletismo e posicionamento familiar de Pseudochryso-hypnum. Quatro espécimes formaram o clado I, não sendo incluídas filogeneticamente no "core" Chryso-hypnum (Fig. 1). Os espécimes de C. diminutivum desse clado apresentam algumas características morfológicas semelhantes aos demais $C$. diminutivum que formam o "core" Chryso-hypnum, como filídios do caulídio semelhante aos dos ramos; costa geralmente curta e dupla, papilas nas duas extremidades da célula e pseudoparáfilo folhoso e filamentoso. No entanto, diferem por apresentar filídios do caulídio e dos ramos com ápice longo estreitamente acuminado, células alares quadradas grandes, formando 2-3 fileiras e células da lâmina com papilas bastante evidentes nas células dos filídios. Isso sugere que esses dois espécimes não pertençam ao gênero Chryso-hypnum. O espécime C. squarrosulum apresenta características semelhantes a C. elegantulum, mas difere desta por apresentar filídios mais espalhados e esquarrosos, ovalados a redondo-ovalados, papilas bem evidentes em ambas as extremidades das células, filídios do caulídio menos cordados e cápsulas ovóides.

Já C. reduncum apresenta características morfológicas completamente diferentes de todos os outros espécimes do "core" Chryso-hypnum, tais como filídios do caulídio fortemente falcado-secundos, ovalado a triangular-ovalado, margens lisas a levemente serruladas, ápice curto-acuminado, células alares pequenas retangulares ou isodiamétricas, pouco visíveis com 1-2 fileiras. Hedenäs (2003) apresentou $C$. reduncum como duvidosa e provável membro do gênero Mittenothamnium, concordando com Ochyra (1999b). Mas as análises filogenéticas deste estudo afirmam o contrário. Portanto, é sugerido que C. reduncum seja revisto como uma espécie pertencente à Amblystegiaceae. 
Resultados do teste SH (Figura 4) mostraram que Pseudochryso-hypnum não se estabeleceu como grupo irmão do "core" Chryso-hypnum, rejeitando seu monofiletismo, sugerindo, assim, que esse clado seja reconhecido como outro gênero, fazendo o conjunto das características referidas acima como possíveis características diagnósticas.

Todas as análises obtidas nesse estudo mostraram que o grupo, Pseudochrysohypnum, sempre permaneceu distante do "core" Chryso-hypnum, e próximo à família Amblystegiaceae. Essa família tem sido tradicionalmente circunscrita por apresentar filídios com costa simples, cápsula cilíndrica e curvada e pela preferência por ambientes úmidos (Hedenäs 2003, Hedenäs \& Vanderpoorten 2007). Nos últimos anos, estudos filogenéticos com bases em dados moleculares e morfológicos conseguiram resolver a relação ao nível genérico fornecendo fortes evidências de que os táxons Amblystegium, Campylium, Drepanocladus e Palustriella (presentes neste estudo) deveriam permanecer nessa família. Kindberg (1885), através de um estudo analítico, observou que Amblystegiaceae era próxima de Hypnaceae. No entanto, Nishimura et al. (1984) diferencia Hypnaceae de Amblystegiaceae por ausência de paráfilos, embora estes ocorram em Campylophyllum e também em alguns táxons de Hypnum; costa curta e dupla, também encontrada em algumas espécies de Campylium, Calliergonella e Drepanocladus. Dessa maneira, nota-se que vários gêneros pertencentes a essas duas famílias não se enquadram nas circunscrições dadas por Nishimura et al. (1984), pois, a maioria dos tratamentos taxonômicos modernos de Amblystegiaceae a coloca juntamente com outras famílias em que as espécies apresentam predominantemente costa longa e única, abandonando a ideia original de que Hypnaceae e Amblystegiaceae, mesmo ambas pertencendo à mesma ordem Hypnales, podem estar morfologicamente relacionadas (Buck 1998; Buck and Vitt 1986; Crum and Anderson 1981; Nyholm 1965; Smith 1978, Vitt 1984). Entretanto, Buck and Vitt (1986) sugeriram que os membros dessas famílias estão apenas distantes, mas podem estar morfologicamente relacionados uns com os outros.

Nossos resultados corroboram, portanto, com os de Cox et al. (2010) e Huttunen et al. (2012) em relação ao monofiletismo de Amblystegiaceae. Espécimes do clado I se diferem em alguns aspectos morfológicos dos os espécimes encontrados em Amblystegiaceae, especialmente no que diz respeito à presença de costa única e longa em Amblystegiaceae (com exceção de Calliergonella) e costa curta e dupla em 
Hypnaceae. Porém, apresentam como características morfológicas semelhantes a presença de pseudoparáfilos folhosos (Cratoneuron, Amblystegium e Campylophyllum), células alares quadradas, células com papilas em ambas as extremidades das células e cilindro central pequeno ou frágil ou ausente. Alguns estudos (Buck 1998, Hugonnot and Hedenäs 2015) sobre as células dos filídios em Amblystegiaceae mostram que alguns espécimes podem apresentar células com papilas em ambas as extremidades (conhecidas tradicionalmente como células proradas). Além disso, tanto os espécimes de Amblystegiaceae desse estudo, como os espécimes do clado Pseudochryso-hypnum, apresentam distribuição neotropical, com algumas espécies ocorrendo no Brasil e América Central, sendo reportados em quase todos os substratos (tronco vivo, tronco em decomposição, rocha e solo) e com altitudes de 0-4000m. Portanto, com base nos dados morfológicos e filogenéticos, é sugerido o reconhecimento do monofiletismo do gênero Pseudochryso-hypnum (nome este considerado, até o momento, informal pelos autores) dentro de Amblystegiaceae.

Monofiletismo de Chryso-hypnum. Três subclados foram apresentados no clado II (Fig. 3), A, B e C. O subclado A é composto por espécimes de Chryso-hypnum elegantulum que compartilham a combinação de caracteres morfológicos como filídios do caulídio patentes, largamente ovalados a triangular-ovalados, base cordada e seta com 2-3 cm de comprimento com cápsulas oblongo-cilíndricas, inclinadas a horizontais. Tais características não foram apresentadas por nenhum outro espécime amostrado na reconstrução filogenética, apresentando, então, quatro características informativas para diferenciá-los. O espécime C. elegantulum (4) se estabeleceu como grupo irmão dos outros C. elegantulum, apresentando bom suporte. Dessa maneira, Chryso-hypnum elegantulum é reconhecido como uma espécie.

O subclado B, formado por três espécimes de Chryso-hypnum diminutivum (1, 2 e 3) compartilham características morfológicas como filídios do caulídio imbricados a patentes, ovalados a curto-elípticos com ápices gradualmente acuminados, seta medindo 1-1,5 cm de comprimento e cápsulas ovóides inclinadas a pêndulas. Tais características são possíveis sinapomorfias para $C$. diminutivum. Assim, há suporte para o monofiletismo de $C$. diminutivum, sendo esta reconhecida como uma espécie.

E o subclado C, apresentou dois espécimes de Chryso-hypnum: C. cavifolium e Chryso-hypnum sp1, oriundos da África e Nicarágua, respectivamente. Ambos 
compartilham células alares grandes, quadradas a subquadradas bem evidentes com 3-5 fileiras. Porém, essas espécies não são morfologicamente semelhantes, portanto não serão sinonimizadas.

Todos os resultados obtidos nesse estudo mostraram que o "core” Chrysohypnum é fortemente suportado como monofilético em todas as análises de ITS, sendo reconhecido nesse trabalho como gênero Chryso-hypnum, e apresentando-se como grupo irmão de três espécies reconhecidas atualmente como membros da família Pylaisiaceae, incluindo Pylaisia polyantha (espécie tipo de Pylaisiaceae). Essa família já foi sinônimo Hypnaceae (Buck 1998). Contudo, Pylaisiaceae por sua vez permaneceu em desuso por muito tempo. Hedenäs (1989) analisando morfologicamente alguns musgos pleurocárpicos reportou que Hypnum cupressiforme, a espécie tipo de Hypnaceae, não está relacionada com a maioria das outras espécies geralmente incluídas nessa família. Tal conclusão foi apoiada por análises moleculares filogenéticas (Arikawa et al. 2008, Cox et al., 2010, Huttunen et al. 2012) que envolveram várias espécies de Hypnaceae como as de Gardiner et al. (2005), onde estes "ressuscitaram" Pylaisiaceae com base em análise filogenética e dados morfológicos, reconhecendo portanto um grupo monofilético bem suportado (Gardiner et al. 2005; Arikawa et al. 2008) para esta família, assim como nesse estudo. Além disso, devido a várias descobertas filogenéticas, observa-se que Pylaisiaceae é uma família para qual várias espécies de Hypnaceae estão sendo transferidas, tais como Calliergonella lindbergii, Ectropothecium andoi, E. regulare, Gollania splendens, Homomalium incurvato, $H$. japonico, várias espécies de Hypnum (H. pallescens, $H$. plicatum, $H$. plumaeforme, $H$. procerrimum, $H$. vaucheri), Ptilium crista-castrensis e Vesicularia vesicularis (Gardiner et al. 2005, Arikawa et al. 2008).

As espécies consideradas como pertencentes à Pylaisiaceae neste estudo (Ectropothecium regulare, Hypnum plumaeforme, Pylaisia polyantha e Vesicularia vesicularis), caracterizam-se por apresentar plantas com filídios homômalos a falcadosecundos, os dos ramos e caulídio pouco diferenciados, células dos filídios lisas ou com papilas em ambas as extremidades, célula alar quadrada a subquadrada, costa curta e dupla (Buck 1998). Características morfológicas estas semelhantes aos espécimes do "core" Chryso-hypnum. Observa-se também que quando comparadas características morfológicas e dados moleculares todos os táxons amostrados dentro do clado II possuem características semelhantes como pseudoparáfilo folhoso e filamentoso; 
filídios ovalados a ovalado-lanceolados; base cordada a levemente cordada; papilas em ambas as extremidades das células; costa curta e dupla; seta avermelhada; cápsula horizontal ou pendente. Características essas que corroboram com os dados moleculares aqui apresentados, levando esses táxons a permanecerem juntos no clado, sendo assim possíveis sinapomorfias para o gênero. Além disso, em todas as análises, os ramos de Chryso-hypnum se apresentaram bem curtos quando comparados aos outros gêneros de Pylaisiaceae (Fig. 1). Tal informação sugere que possa ter ocorrido uma recente e rápida diversificação do gênero (Shaw et al., 2003).

Os espécimes de Pylaisiaceae deste estudo, assim como os espécimes que formam o "core" Chryso-hypnum, apresentam distribuição neotropical, ocorrendo em todos os substratos (tronco vivo, tronco em decomposição, rocha e solo) e com altitudes de 0-2800m. Portanto, com base nos dados moleculares, morfológicos e análises filogenéticas (apesar de apresentar suporte fraco) aqui apresentados, é sugerido o reconhecimento do gênero Chryso-hypnum dentro de Pylaisiaceae.

Monofiletismo e posicionamento familiar do gênero Mittenothamnium. Todos os espécimes do clado III (Figura 3) são oriundos do novo mundo. O subclado A é composto por dois espécimes de Mittenothamnium: M. reptans (1) e M. reptans (2) que compartilham mesmo formato do filídio do caulídio e dos ramos, filídios dos ramos com margem serreada do ápice até metade do filídio, papila apenas na porção superior da célula, pseudoparáfilo triangular. Já o subclado B é composto por dois espécimes da Bolívia: M. substriatum e Mittenothamnium sp2 que compartilham filídios dos ramos com margem serrulada do ápice até bem próximo à base, células alares pequenas com 23 fileiras e papilas bem evidentes no ápice dos filídios. $M$. substriatum se diferencia dos demais espécimes de Mittenothamnium por apresentar filídios do caulídio e dos ramos similares e maiores com 1.7-2.15 mm de comprimento, sendo que os demais espécimes de Mittenothamnium apresentam cerca de 0.45-1.3 mm de comprimento. Essas duas espécies não são morfologicamente semelhantes, portanto não serão sinonimizadas.

O espécime $M$. reptans (4) se estabeleceu como grupo irmão de $M$. substriatum e Mittenothamnium sp2 compartilhando características morfológicas como filídios dos ramos com margem serrulada do ápice até a base. $M$. reptans (3) também se estabeleceu como grupo irmão, para os espécimes citados anteriormente. Porém, a seqüência de DNA desse espécime foi retirada do Genbank, sem possibilidade de observar a exsicata. 
Já o espécime Mittenothamnium sp1, se apresentou como grupo irmão dos dois subclados citados cima. Esse espécime apresenta características morfológicas exclusivas: filídios do caulídio e dos ramos ovalados a ovalado-triangulares, base cordada, algumas vezes profundamente cordada (decurrente), célula alar retangular com 2-5 fileiras e célula linear menos alongada. Assim, Mittenothamnium sp1 pode ser reconhecida como espécie nova e o conjunto das características referidas se faz como possíveis sinapomorfias. E M. scalpellifolium apareceu como grupo irmão de Mittenothamnium sp1. Também é uma espécie que apresenta características morfológicas exclusivas, tais como ramos fortemente complanados-foliados, filídios do caulídio e dos ramos patentes a esquarrosos, ovalados a ligulados e ápice curtoacuminado. Essas características se fazem como possíveis sinapomorfias, podendo $M$. scalpellifolium ser reconhecida como espécie.

No entanto, a seqüência de Mittenothamnium loriforme não está incluída filogeneticamente no core Mittenothamnium (Figura 1). A amostra é reconhecida tradicionalmente como a espécie de $M$. loriforme por apresentar características morfológicas semelhantes para o gênero, tais como, caulídio estipitado, células do filídio projetando papilas apenas no ápice e pseudoparáfilo triangular e folhoso. Dessa maneira, tais informações sugerem que M. loriforme (Basiônimo: Hypnum loriforme Hampe) continue pertencendo ao gênero Mittenothamnium. Para auxiliar nessa afirmação foi realizado o teste $\mathrm{SH}$, onde o resultado mostrou que essa espécie se estabeleceu como grupo irmão de todos os outros Mittenothamnium, não rejeitando seu monofiletismo (Figura 5). Além disso, M. loriforme compartilha características com os demais Mittenothamnium deste estudo: caulídio estipitado, pseudoparáfilo folhoso e papilas apenas na porção superior da célula. Portanto, M. loriforme continua reconhecida como pertencente à Mittenothamnium.

Todos os resultados obtidos nesse estudo mostraram que o "core" Mittenothamnium é suportado como monofilético em todas as análises, sendo reconhecido nesse trabalho como gênero e apresentando-se como grupo irmão de Taxiphyllum wisgrillii, ainda pertencente à Hypnaceae, corroborando com os dados de Arikawa et al. (2008) e Huttunen et al. (2012), onde esse espécime aparece junto, assim como nesse estudo, como grupo irmão de duas espécies reconhecidas filogeneticamente como Hypnaceae: Hypnum cupressiforme (espécie tipo de Hypnaceae) e Eurohypnum leptothallum (Cox et al. 2010, Huttunen et al. 2012). As análises filogenética deste 
trabalho somam novas evidências sobre o polifiletismo de Hypnaceae, corroborando com os estudos de Arikawa et al. (2008), Cox et al. (2010) e Huttunen et al. (2012), sugerindo o reconhecimento do gênero Mittenothamnium como monofilético dentro de Hypnaceae, apesar do baixo suporte. Além disso, os dois espécimes de Hypnaceae citados acima, assim como os espécimes que formam o "core" Mittenothamnium, apresentam distribuição neotropical, ocorrendo em todos os substratos (tronco vivo, tronco em decomposição, rocha e solo) e com altitudes de 0-1700m.

Buck (2007) apontou que a combinação de vários genes com a observação detalhada da morfologia deve nos fornecer uma classificação estável. Esse mesmo autor também mencionou que até o momento, o maior grupo entre os musgos que necessita de uma resolução filogenética é Hypnales.

Contudo, é necessário juntar estudos de caracteres taxonômicos mais eficazes, com uma reconstrução filogenética mais apropriada de vários marcadores a fim de construir uma árvore filogenética com maior resolução e assim apresentar dados para circunscrever melhor as famílias Pylaisiaceae e Hypnaceae.

Portanto, conclui-se com este estudo que: 1) O marcador molecular individual ITS se mostrou eficiente para definir o monofiletismo do "core" Pseudochryso-hypnum, Chryso-hypnum e Mittenothamnium; 2) O nome Pylaisiaceae é aqui sugerido para agregar os espécimes de Chryso-hypnum deste estudo; 3) as reconstruções mostraram três core monofiléticos aqui apresentados como: Pseudochryso-hypnum, Chrysohypnum e Mittenothamnium, apresentando informações para uma revisão taxonômica clássica para os grupos; 4) com os dados filogenéticos podemos reconhecer pelo menos três espécies para Pseudochryso-hypnum, quatro espécies para Chryso-hypnum: $C$. cavifolium, C. diminutivum, C. elegantulum e Chryso-hypnum sp1. E para Mittenothamnium pode-se reconhecer pelo menos seis espécies: M. loriforme, $M$. reptans, M. scalpellifolium, M. substriatum, Mittenothamnium sp1 e Mittenothamnium $\mathrm{sp} 2$.

\section{Agradecimentos}

Os autores agradecem os curadores dos herbários visitados e pelos empréstimos concedidos: Dr. William R. Buck (NY), Bruce Allen (MO) e Denilson F. Peralta (SP). E a Instituição de fomento de aperfeiçoamento de pessoal de nível superior (CAPES) pela bolsa concedida. 


\section{Referências Bibliográficas}

Akaike, H. 1973. Information theory and an extension of the maximum likelihood principle. In B. N. Petrov and F. Csaki (Eds.), Second international symposium on information theory. Budapest: Academiai Kiado. 44:267-281.

Arikawa, T. and M. Higuchi. 1999. Phylogenetic analysis of the Plagiotheciaceae (Musci) and its relatives based on $r b c L$ gene sequences. Cryptogamie, Bryologie. 20 : 231-245.

Arikawa, T. and M. Higuchi. 2003. Preliminary phylogenetic analysis of Pylaisia (Hypnaceae, Musci) and its relatives based on $r b c L$ gene sequences. Journal of the Hattori Botanical Laboratory. 94: 87-106.

Arikawa, T., H. Tsubota, H. Deguchi, N. Nishimura, and M. Higuchi. 2008. Phylogenetic analysis of the family Hypnaceae based on rbcL gene sequences. - In: Mohamed, H.; Bakar, B. H.; Boyce, A. N. and Lee, P. (Eds). Bryology in the New Millennium, Kuala-Lumpur. University of Malaysia. 215-225.

Britton, E. G. 1914. Notes on Nomenclature. XII. The Bryologist. 17: 1-10.

Brotherus, V. F. 1925. Musci (Laubmoose). 2. Hälfte. In A. Engler, Die Natürlichen Pflanzenfamilien. Leipzig.

Buck, W. R. 1984. Taxonomic and nomenclatural notes on West Indian Hypnaceae. Brittonia. 36: 178-183.

Buck, W. R. 1998. Pleurocarpous Mosses of West Indies. Memoirs of the New York Botanical Garden. 82: 1-400.

Buck, W. R. 2003. Guide to the Plants of Central French Guiana. Part 3. Mosses. Memoirs of the New York Botanical Garden. 76:1-167.

Buck, W. R. 2007. The history of pleurocarp classification: two steps forward, one step back. In: Newton AE, Tangney RS, eds. Pleurocarpous Mosses: Systematics and Evolution. Boca Raton: CRC Press. 71:1-18.

Buck, W. R. 2014. Chryso-hypnum. In: Flora of North America, Bryophytes: Mosses, part 2. Flora of North America Editorial Committee. 28:520.

Buck, W. R. and B. Goffinet. 2000. Morphology and Classification of Mosses. In: A.J. Shaw and B. Goffinet (eds.). Bryophyte Biology. University Press, Cambridge. 71123 
Buck, W. R. and D. H. Vitt. 1986. Suggestions for a new familial classification of pleurocarpous mosses. Taxon. 35: 21-60.

Buck, W. R., B. Goffinet, and A. J. Shaw. 2000. Testing morphological concepts of orders of pleurocarpous mosses (Bryophyta) using phylogenetic reconstructions based on trnL-trnF and rps4 sequences. Molecular Phylogenetic Evolution. 16: 180-198.

Buck, W. R., C. J. Cox, A. J. Shaw, and B. Goffinet. 2005. Ordinal relationships of pleurocarpous mosses, with special emphasis on the Hookeriales. Systematics and Biodiversity. 2: 121-45.

Câmara, P. E. A. S. 2009. Métodos de Extração de DNA de Bryophyta para Análises Filogenéticas. Heringeriana. 3: 11-17.

Câmara, P. E. A. S., and J. Shaw. 2013. A re-interpretation of the Fabroniaceae, a phylogenetic perspective A re-interpretation of the Fabroniaceae, a phylogenetic perspective. The Bryologist. 1: 109-117.

Chiang, T. Y. and B. Schaal. 2000. The internal transcriber spacer 2 region on nuclear ribosomal DNA and the phylogeny of the moss family Hylocomiaceae. Plant Systematics and Evolution. 224: 127-137.

Cox, C. J., B. Goffinet, A. J. Shaw, and S. B. Boles. 2004. Phylogenetic relationships among the mosses based on heterogeneous bayesian analysis of multiple genes from multiple genomic compartments. Systematic Botany. 29: 234-250.

Cox, C. J., B. Goffinet, N. S. Wickett, S. Boles, and J. Shaw. 2010. Moss diversity: A molecular phylogenetics analysis of genera. Phytotaxa. 9: 175-195.

Crum, H. and L. E. Anderson. 1981. Mosses of Eastern North America. Columbia University Press, New York.

Darriba D., G. L. Taboada, R. Doallo, and D. Posada. 2012. JModelTest 2: more models, new heuristics and parallel computing. Nature Methods. 8: 772.

De Luna, E., A. E. Newton, A. Withey, D. Gonzalez, and B. D. Mishler. 1999. The Transition to Pleurocarpy: A Phylogenetic Analysis of the Main Diplolepidous Lineages Based on rbcl Sequences and Morphology. The Bryologist. 102:634-650

Doyle, J. J. and J. L. Doyle. 1987. A rapid DNA isolation procedure for small quantities of fresh leaf tissue. Phytochemical Bulletin. 19:11-15.

Felsenstein, J. 1985. Confidence limits on phylogenies: an approach using the bootstrap. Evolution 39: 779-783.

Fleischer, M. 1908. Die Musci der Flora Von Buitenzorg. 3: 949. 
Florschütz-de Waard, J. and K. Veling, 1996. Flora of the Guianas. Royal Botanic Gardens, Kew. 1: 439-461.

Gardiner, A., M. Ignatov, S. Huttunen, and A. Troitsky. 2005. On resurrection of the families Pseudoleskeaceae Schimp. and Pylaisiaceae Schimp. (Musci, Hypnales). Taxon. 54: 651-663.

Goffinet, B., and W. R. Buck. 2004. Systematics of the Bryophyta (mosses): from molecules to a revised classification. Monographs in Systematic Botany from the Missouri Botanical Garden. 98: 205-239.

Goffinet, B. and A. J. Shaw. 2009. Bryophyte Biology. $2^{\text {nd }}$ edition. Cambridge University, Cambridge. 119-120.

Goffinet, B., W. R. Buck. And J. Shaw. 2009. Morphology and Classification of the Bryophyta. In: B. Goffinet and J. Shaw (Eds.). Bryophyte Biology. Cambridge University Press. 2: 55-138.

Gradstein, S. R., S. P. Churchill, and N. Salazar-Allen, 2001. Guide to the Bryophytes of Tropical America. Memoirs of the New York Botanical Garden. 86: 1-577.

Guindon, S. and O. Gascuel. 2003. A simple, fast and accurate method to estimate large phylogenies by maximum-likelihood. Systematic Biology. 52: 696-704.

Hampe, E. L. 1870. Botanische Zeitung (Berlin), p. 35.

Hedenäs, L. 1989. Some neglected character distribution patterns among the pleurocarpous mosses. Bryologist. 92: 157-163.

Hedenäs, L. 2003. Amblystegiaceae (Musci). Flora Neotropica, Monograph 89: 1-107.

Hedenäs, L., and A. Vanderpoorten. 2007. The Amblystegiaceae and Calliergonaceae. In: A. E. Newton and R. S. Tangney (eds.). Pleurocarpous Mosses: Systematics and Evolution. 71:163-176.

Hennings, P. C. 1902. Organ fur Kryptogamenkunde und Phytopathologie. Dresden. Hedwigia 41: 225.

Hugonnot, V. and L. Hedenäs. 2015. Arvernella microclada Hugonnot \& Hedenäs (Amblystegiaceae), a new minute species from France, requiring a separate genus. Journal of Bryology. 37: 184-191.

Huttunen, S., N. Bell, V. K. Bobrova, V. Buchbender, W. R. Buck, C. J. Cox, B. Goffinet, L. Hedenäs, B. C. Ho, M. Ignatov, M. Krug, O. Kuznetsova, I. Milyutina, A. Newton, S. Olsson, L. Pokorny, A. J. Shaw, M. Stech, A. Troitsky, A. 
Vanderpoorten, and D. Quandt. 2012. Disentangling knots of rapid evolution: origin and diversification of the moss order Hypnales. Journal of Bryology. 34: 187-202.

Kindberg, N. C. 1885. Table analytique des Mousses pleurocarpes européennes. Revue Bryologique. 12: 24-31.

Larkin, M. A., G. Blackshields, N. P. Brown, R. Chenna, P. A. McGettigan, H. McWilliam, F. Valentin, I. M. Wallace, A. Wilm, R. Lopez, J. D. Thompson, T. J. Gibson, and D. G. Higgins. 2007. Clustal W and Clustal X version 2.0. Bioinformatics. 23: 2947-2948.

Maddison, W. P. and D. R. Maddison. 2015. Mesquite: a modular system for evolutionary analysis. Versão 3.04. http://mesquiteproject.wikispaces.com.

Müller, K. F. 2005. SeqState-primer design and sequence statistics for phylogenetic DNA data sets. Applied Bioinformatics. 4: 65-69.

Miller, M. A., W. Pfeiffer, and T. Schwartz. 2010. Creating the CIPRES Science Gateway for inference of large phylogenetic trees. Proceedings of the Gateway Computing Environments Workshop (GCE), New Orleans, LA. 1 - 8.

Müller, K., D. Quandt, J. Müller, and C. Neinhuis. 2006. PhyDE ®: Phylogenetic Data Editor. www.phyde.de.

Nadot, S., R. Bajon, and B. Lejeune. 1994. The choloroplast gene rps4 as a tool for the study of Poaceae phylogeny. Plant Systematics and Evolution. 191: 27-38.

Newton, A. E., C. J. Cox, J. G. Duckett, J. A. Wheeler, B. Goffinet, T. A. J. Hedderson, and B. D. Mishler. 2000. Evolution of the Major Moss Lineages: Phylogenetic Analyses Based on Multiple Gene Sequence and Morphology. The Bryologist. 103: 187-211.

Newton, A. E., N. Wikstrom, N. Bell, L. L. Forrest, and M. S. Ignatov. 2007. Dating the Diversification of the Pleurocarpous Mosses. In: A. E. Newton and R. S. Tangney (Eds.). Pleurocarpous Mosses - Systematics and Evolution. Boca Raton: CRC Press. 337-366.

Nishimura, N. and H. Ando. 1986. A Revision of Some Mittenothamnium Species Described from Mexico. The Bryologist. 89: 66-69.

Nishimura, N., M. Higuchi, T. Seki, and H. Ando. 1984. Delimitation and subdivision of the moss family Hypnaceae. Journal of the Hattori Botanical Laboratory. 55: 227-234. 
Nyholm, E. 1965. Illustrated Moss Flora of Fennoscandia. II, Musci. Fasc. 5. C. W. K. Gleerup, Lund.

Ochyra, R. 1999b. New combinations in neotropical mosses. Fragm. Florist. Geobot. 44:255-259.

Pedersen, N. and L. Hedenäs. 2002. Phylogeny of the Plagiotheciaceae based on molecular and morphological evidence. The Bryologist. 105: 310-324.

Rambaut, A. 2012. FigTree, versão 1.4.0. Available: http://tree.bio.ed.ac.uk/software/figtree/.

Rambaut, A. and A. J. Drummond. 2013. Tracer v.1.5. Available: http://beast.bio.ed.ac.uk/Tracer.

Ronquist, F. and J. P. Huelsenbeck. 2015. MRBAYES 3: Bayesian phylogenetic inference under mixed models. Bioinformatics. 19: 1572-1574.

Sharp, A. J., H. A. Crum, and P. Eckel. 1994. The Moss Flora of Mexico. Memoirs of The New York Botanical Garden. 69: 1-1113.

Shaw, A. J., C. J. Cox, B. Goffinet, W. R. Buck, and S. B. Boles. 2003. Phylogenetics evidence of a rapid radiation of Pleurocarpous mosses (Bryophyta). Evolution. 57: 2226-2241.

Simmons, M. P. and Ochoterena, H. 2000. Gaps as characters in sequence-based phylogenetic analyses. Systematic Biology. 49:349-381.

Smith, A. J. E. 1978. The Moss Flora of Britain and Ireland. Cambridge University Press, Cambridge.

Stamatakis, A. 2014. RAxML Version 8: A tool for Phylogenetic Analysis and PostAnalysis of Large Phylogenies. Bioinformatics. 30:1312-3.

Swofford, D. L. 2002. PAUP*. Phylogenetic analysis using parsimony (*and other methods). Versão 4. Sunderland: Sinauer Associates.

Tropicos.org. Missouri Botanical Garden. 2016. http://www.tropicos.org

Tsubota, H., N. Nakao, H. Akiyama, T. Yamaguchi, M. Higuchi, H. Deguchi, and T. Seki. 1999. A preliminary phylogeny of Hypnales (Musci) as inferred from chloroplast rbcL sequence data. Bryological Research. 7: 233-48.

Tsubota, H., H. Akiyama, T. Yamaguchi, and H. Deguchi. 2001a. Molecular phylogeny of the Sematophyllaceae (Hypnales, Musci) based on chloroplast rbcL sequences. The Journal of the Hattori Botanical Laboratory. 90: 221-240. 
Tsubota, H., H. Akiyama, T. Yamaguchi, and H. Deguchi. 2001b. Molecular phylogeny of the genus Trismegistia and related genera (Sematophyllaceae, Musci) based on chloroplast rbcL sequences. Hikobia. 13: 529-549.

Vanderpoorten, A., M. S. Ignatov, S. Huttunen, and B. Goffinet. 2005. A molecular and morphological recircumscription of Brachytheciastrum (Brachytheciaceae, Bryopsida). Taxon. 54: 369-376.

Vitt, D. H. 1982. Bryopsida. In: Parker S.P. (Ed.), Synopsis and Classification of Living Organisms. McGraw-Hill Book Company. New York. 307-336.

Vitt, D. H. 1984. Classification of the Bryopsida. In New Manual of Bryology, Vol. 2 (ed. R. M. Schuster). Hattori Botanical Laboratory. Miyazaki. 696-759.

White, T. J., T. Bruns, S. Lee, and J. Taylor. 1990. Amplification and direct sequencing of fungal ribossomal RNA genes for phylogenetic. In: "PCR protocols: A Guide to Methods and Applications". 315-322.

www.phylo.org < ultimo acesso em setembro de 2016>. 
Tabela 1. Sequências produzidas nesse estudo. Informações do Voucher: Coletor, número coletor, herbário. (*) Sequências obtidas (-) seqüências sem sucesso na amplificação.

\begin{tabular}{|c|c|c|c|c|c|}
\hline Amostra & Informação do Voucher & Local de coleta & Its & $26 S$ & rps4 \\
\hline Chryso-hypnum cavifolium & Allen, $30608(\mathrm{MO})$ & África & $*$ & - & - \\
\hline Chryso-hypnum diminutivuml & Gama et al., 935 (UB) & Brasil & $*$ & - & $*$ \\
\hline Chryso-hypnum diminutivum2 & Soares and Salmito, 1356 (UB) & Brasil & $*$ & - & - \\
\hline Chryso-hypnum diminutivum 3 & Silva-Junior, 08 (UB) & Brasil & $*$ & - & $*$ \\
\hline Chryso-hypnum spl. & Magill, 14950 (MO) & Nicarágua & $*$ & - & - \\
\hline Chryso-hypnum diminutivum & Ferreira, $29(\mathrm{SP})$ & Brasil & $*$ & $*$ & $*$ \\
\hline Chryso-hypnum diminutivum & Silva-Junior, 14 (UB) & Brasil & - & $*$ & - \\
\hline Chryso-hypnum diminutivum & Reese, 17992 (MO) & Caribe (ilha) & $*$ & - & - \\
\hline Chryso-hypnum diminutivum & Rojas, 5350 (MO) & Peru & - & $*$ & - \\
\hline Chryso-hypnum elegantulum1 & Câmara et al., 2876 (UB) & Brasil & $*$ & $*$ & $*$ \\
\hline Chryso-hypnum elegantulum 2 & Chacon et al., 379 (UB) & Brasil & $*$ & $*$ & $*$ \\
\hline Chryso-hypnum elegantulum3 & Soares et al., 814 (UB) & Brasil & $*$ & * & $*$ \\
\hline Chryso-hypnum elegantulum4 & Pirani, 6197 (SP) & Brasil & $*$ & - & - \\
\hline Chryso-hypnum frondosum & Frey and Kürschner, 6987(NY) & África & - & - & $*$ \\
\hline Chryso-hypnum sp2. & Câmara, $1378(\mathrm{MO})$ & Malásia & - & - & $*$ \\
\hline Chryso-hypnum squarrosulum & Fuertes and Prada, s.n (NY) & Argentina & - & * & $*$ \\
\hline Chryso-hypnum squarrosulum & Pursel, $11890(\mathrm{MO})$ & Suriname & $*$ & - & - \\
\hline Mittenothamnium loriforme & Opisso and Lingán, 1826 (MO) & Peru & $*$ & - & - \\
\hline Mittenothamnium reduncum & Peralta, $10839(\mathrm{SP})$ & Brasil & $*$ & - & - \\
\hline Mittenothamnium reduncum & Churchill and Parra, 18803 (NY) & Colômbia & - & - & $*$ \\
\hline Mittenothamnium reptans1 & Davis, $390(\mathrm{MO})$ & Costa Rica & $*$ & * & $*$ \\
\hline Mittenothamnium reptans 3 & Inturias et al., $723 A(\mathrm{MO})$ & Bolívia & $*$ & - & - \\
\hline Mittenothamnium reptans 4 & Rios and Castillo, s.n (MO) & Guatemala & $*$ & - & - \\
\hline Mittenothamnium reptans & Sartori, $134(\mathrm{MO})$ & Brasil & $*$ & - & - \\
\hline Mittenothamnium reptans & Price, $1643(\mathrm{NY})$ & Argentina & - & * & - \\
\hline Mittenothamnium scalpellifolium & Magill, 14642 (MO) & Nicarágua & $*$ & - & - \\
\hline Mittenothamnium substriatum & Apaza et al., 90 (MO) & Bolívia & $*$ & - & - \\
\hline Mittenothamnium spl & Castrejón et al., 1390 (MO) & México & $*$ & $*$ & - \\
\hline Mittenothamnium sp2 & Churchill et al., 22909 (NY) & Bolívia & $*$ & - & - \\
\hline
\end{tabular}


Tabela 2. Espécies do Genbank com suas respectivas sequências utilizadas nas análises. (-) Seqüência ausente no Genbank. Marcadores moleculares: ITS, 26S e rps4.

\begin{tabular}{|c|c|c|c|}
\hline Espécie & ITS & $26 S$ & rps4 \\
\hline Abietinella abietina & AY009802 & - & AY907953 \\
\hline Acrocladium auriculatum & AF543550 & HM751247 & AJ862338 \\
\hline Acrocladium chlamydophyllum & AF509863 & - & AJ862339 \\
\hline Acroporium pungens & HE660023 & HM751374 & AY908207 \\
\hline Amblystegium serpens & AF464987 & - & AY908237 \\
\hline Andoa berthelotiana & FM161074 & HM751480 & FM161239 \\
\hline Anomodon viticulosus & FM161076 & HM751351 & HE717066 \\
\hline Brachythecium rivulare & FM161081 & - & AM990348 \\
\hline Brotherella recurvans & - & HM751708 & AY908227 \\
\hline Calliergon cordifolium & AY625984 & HM751346 & AF469844 \\
\hline Camptochaete arbuscula & FM161087 & HM751473 & AY908330 \\
\hline Campylium chrysophyllum & AF168150 & HM751410 & AF143048 \\
\hline Campylium stellatum & AF403609 & HM751409 & HE717067 \\
\hline Chaetomitrium $s p$ & HE660025 & - & AY306881 \\
\hline Chrysohypnum diminutivum & HE660008 & - & AY908345 \\
\hline Claopodium whippleanum & AY173458 & HM751484 & AY908294 \\
\hline Clasmatodon parvulus & DQ200082/AF403614 & HM751317 & AY663329 \\
\hline Climacium americanum & HE660004 & HM751424 & AY908573 \\
\hline Cratoneuron filicinum & AF168155 & HM751422 & AY908250 \\
\hline Cryphaea amurensis & FM161090 & - & AM990355 \\
\hline Cryphaeophilum molle & AF509840 & - & HE717068 \\
\hline Ctenidium molluscum & AF230989/AF403632 & HM751482 & AY907954 \\
\hline Drepanocladus aduncus & AF180949 & HM751415 & AY908241 \\
\hline Duthiella wallichii & HE660013/AF403612 & HM751693 & AY908286 \\
\hline Ectropothecium regulare & HE660009 & - & HE717069 \\
\hline Entodon seductrix & JN896314 & - & HE717070 \\
\hline Entodontopsis leucostega & AY999175 & HM751306 & AY908295 \\
\hline Eriodon conostomus & - & HM751412 & AY908239 \\
\hline Erythrodontium longisetum & AY255497 & HM751280 & AY908256 \\
\hline Eurohypnum leptothallum & AY695733/AY695786 & HM751455 & AY908203 \\
\hline Forsstroemia trichomitria & FM161103 & HM751469 & AY908263 \\
\hline Haplohymenium triste & AM990374 & - & AY908202 \\
\hline Helodium blandowii & AY009803 & HM751287 & AY908339 \\
\hline Hildebrandtiella guyanensis & FM161119 & - & AY306927 \\
\hline Homalothecium lutescens & EF617558 & - & HE717071 \\
\hline Hydropogon fontinaloides & HE660024 & HM751382 & AY908216 \\
\hline Hylocomiastrum umbratum & FM161141 & - & AM990396 \\
\hline Hylocomium splendens & HE660006/AF403610 & HM751348 & AY908280 \\
\hline Hypnodendron vitiense & FM161142 & - & AY524471 \\
\hline Hypnuт сирressiforme & FM161143 & HM751456 & AM990398 \\
\hline Hypnum plumaeforme & AY695743/AY695768 & - & - \\
\hline Нурпит рrocerrimuт & - & - & HE717073 \\
\hline
\end{tabular}




\section{Continuação da Tabela 2}

\begin{tabular}{|c|c|c|c|}
\hline Espécie & Its & $26 S$ & rps4 \\
\hline Hypopterygium tamarisci & HE660000 & EF680816 & AY449666 \\
\hline Isopterygium tenerum & HE660021 & HM751395 & AF143037 \\
\hline Leptodon smithii & FM161147 & HM751467 & AY908261 \\
\hline Lescuraea incurvata & AY693661 & - & - \\
\hline Lescuraea radicosa & AF516169/AF516147 & HM751341 & AY908326 \\
\hline Leskea polycarpa & AY528881 & - & HE717074 \\
\hline Lindbergia brachyptera & FM161151 & HM751276 & AM990407 \\
\hline Mesonodon flavescens & AY255502 & HM751281 & AY908255 \\
\hline Meteoriella soluta & AF403606 & HM751368 & AY306950 \\
\hline Meteoriopsis reclinata & HE660014/AF403666 & HM751488 & AY306948 \\
\hline Meteorium illecebrum & HE660015/AF188046 & HM751496 & AY908187 \\
\hline Mittenothamnium reptans & HE660010 & - & AY908346 \\
\hline Myrinia pulvinata & AY528886/AY528887 & - & HE717075 \\
\hline Myurium hochstetteri & HE660026/AF509861 & HM751481 & AY908180 \\
\hline Neckera complanada & FM201492 & - & - \\
\hline Neckera pennata & AY009809 & HM751465 & AY908265 \\
\hline Orthostichella ampullacea & - & - & - \\
\hline Orthostichella pentasticha & HE660017/AY429502 & HM751362 & AY907962 \\
\hline Orthostichidium involutifolium & - & HM751429 & AY908195 \\
\hline Orthostichopsis tetragona & HE660020 & HM751439 & AY908192 \\
\hline Palustriella falcata & AF168158 & HM751417 & AY908243 \\
\hline Pilosium chlorophyllum & GU568689 & HM751246 & AF143059 \\
\hline Pleuroziopsis ruthenica & AY999170 & HM751425 & AY908571 \\
\hline Porotrichodendron robustum & FM161197 & - & AM990426 \\
\hline Prionodon densus & HE660019 & HM751443 & AF143076 \\
\hline Pseudoleskeella tectorum & AF516168/AY695776 & HM751279 & AY907950 \\
\hline Pterogonium gracile & HE660012 & HM751337 & AY907970 \\
\hline Ptychodium plicatum & AY695740/AY695765 & HM751342 & AY908327 \\
\hline Pylaisia polyantha & AY528881 & - & AY907960 \\
\hline Regmatodon declinatus & - & HM751278 & AY908191 \\
\hline Rhytidiadelphus triquetrus & HE660005/AF403631 & HM751349 & AM990396 \\
\hline Rhytidium rugosum & AY009801 & - & AY907951 \\
\hline Rigodium implexum & FM161209 & - & AM990436 \\
\hline Sanionia sp & AF168148 & - & AY908253 \\
\hline Scorpidium scorpioides & AY625995 & HM751270 & AY908584 \\
\hline Sematophyllum demissum & - & HM751381 & AY908214 \\
\hline Spiridentopsis longissima & - & HM751440 & AY908564 \\
\hline Stereophyllum radiculosum & AY999176 & - & AF469846 \\
\hline Straminergon stramineum & AM946398 & - & AM990351 \\
\hline Symphyodon imbricatifolius & FM161214 & - & AY306999 \\
\hline Taxiphyllum wissgrillii & AY999168 & - & AF469842 \\
\hline Taxithelium planum & - & HM751396 & AY908231 \\
\hline
\end{tabular}




\section{Continuação Tabela 2}

\begin{tabular}{lccc}
\hline Espécie & ITS & 26S & rps4 \\
\hline Thamnobryum alopecurum & FM161218 & HM751367 & AF023834 \\
Thamniopsis sinuata & HQ443779 & - & AY307004 \\
Thelia lescurii & AJ288411/AJ277223 & HM751454 & AF143024 \\
Toloxis imponderosa & FM161232/AF395631 & HM751497 & AY908289 \\
Trachypus bicolor & DQ200118/AF395624 & HM751495 & AY908290 \\
Vesicularia vesicularis & HE660011 & HM751406 & AY908559 \\
Vittia pachyloma & AY062886 & HM751705 & AY908240 \\
Weymouthia mollis & FM161237 & HM751475 & AY307013 \\
& & & \\
\hline
\end{tabular}

Tabela 3: Primers e temperaturas de anelamento utilizados nesse estudo.

\begin{tabular}{lcc}
\hline \multicolumn{1}{c}{ Marcador } & Referência & \multicolumn{2}{c}{ Temperatura de anelamento $\mathbf{C}^{\circ}$} \\
\hline rps4 F & Nadot et al., 1994 & $50-54$ \\
rps4 R & Nadot et al., 1994 & $50-54$ \\
26 S R & Shaw 2000 & $50-62$ \\
26S F & Shaw 2000 & $50-62$ \\
ITS & White et al. 1990 & $51-69$ \\
\hline
\end{tabular}


Tabela 4. Estatísticas individuais para cada marcador utilizado e da análise combinada. $\mathrm{CI}=$ índice de consistência; RI= índice de retenção e HI= Índice de homoplasia.

\begin{tabular}{ccccc}
\hline & ITS & 26S & Rps4 & ITS+26S+rps4 \\
\hline Táxons incluídos & 104 & 69 & 100 & 121 \\
Comprimento da matriz & 3177 & 1174 & 795 & 5148 \\
Comprimento da árvore & 2425 & 617 & 880 & 4077 \\
Caracteres constantes & 2567 & 906 & 407 & 3883 \\
Caracteres variáveis & 261 & 133 & 217 & 608 \\
aracteres informativos na MP & 349 & 135 & 171 & 657 \\
Número de árvores & 10000 & 10000 & 10000 & 10000 \\
CI & 0,401 & 0,545 & 0,558 & 0,441 \\
RI & 0,599 & 0,660 & 0,556 & 0,573 \\
HI & 0,599 & 0,455 & 0,442 & 0,599 \\
Modelo de Evolução & TPM1uf+I+G & TIM1+I+G & GTR+G & TVMEf+I+G \\
\hline
\end{tabular}




\title{
CAPÍTULO 2
}

A ser submetido para a revista The Bryologist

\section{Morfologia dos esporos e desenvolvimento das papilas (células proradas) nos filídios de Chryso-hypnum Hampe e Mittenothamnium Hennings (Hypnaceae).}

\author{
Osvanda Silva de Moura ${ }^{1}$ \& Paulo Eduardo A. S. Câmara ${ }^{1}$ \\ ${ }^{1}$ Universidade de Brasília, Depto de Botânica. Campus Universitário Darcy Ribeiro, \\ Asa Norte, Brasília, DF. Brasília 70910-970. \\ ${ }^{1}$ Autor para correspondência (osvanda@hotmail.com)
}

Resumo - A morfologia do esporófito tem sido tradicionalmente utilizada na separação dos táxons entre os musgos pleurocárpicos. Em Hypnaceae a morfologia do gametófito ainda apresenta caracteres interessantes e pouco investigados. O objetivo do trabalho foi analisar a morfologia dos esporos e o desenvolvimento das células proradas (papilas) nos filídios de Chryso-hypnum Hampe e Mittenothamnium Henn., buscando caracteres morfológicos informativos para esse táxons, com auxílio de microscopia eletrônica de varredura. Os espécimes foram observados sob MEV e posteriormente eletromicrografados. Foi encontrado apenas um tipo de papila em Chryso-hypnum e Mittenothamnium, denominada de papila cônica, divididas de duas formas de acordo com a morfologia e estágio de desenvolvimento: madura e imatura. Com relação aos esporos, a ornamentação observada em todas as espécies estudadas foi granulada, apresentando, entretanto, variações no tamanho e na disposição dos grânulos: em Chryso-hypnum os grânulos estão dispostos de maneira densa sobre a superfície do esporo, cobrindo toda a exina; e em Mittenothamnium a exina apresenta-se total ou parcialmente coberta, permitindo, algumas vezes, a visualização da mesma. Os resultados sugerem que as papilas e os esporos são informativos e são possíveis sinapomorfias para alguns clados.

Palavras-chaves: Bryophyta, Papilas, Esporos, Microscopia Eletrônica de Varredura. 
Abstract - Morphology of the sporophyte has been traditionally used in the separation of taxa among pleurocarpous mosses. In Hypnaceae, the morphology of the gametophyte still presents interesting yet under investigated characteristics. The objective of this study was to investigate the morphology of spores and the development of prorate cells (papillae) in the leaf of Chryso-hypnum and Mittenothamnium, and thus to obtain a more detailed understanding of the morphology of these two genera using scanning electron microscopy. The specimens were observed under scanning electron microscopy and then electromicrographed. In both Chryso-hypnum and Mittenothamnium, only one type of papillae, know as the conical papillae, was found. The observed conical papillae can be divided into two forms, mature or immature, depending on its morphology and stage of development. Regarding the spores, the granulated ornamentation has been observed in all species studied, presenting variations, however, in the size and arrangement of the granules: in Chryso-hypnum the granules are densely arranged on the surface of the spore, covering all exine; in Mittenothamnium the exine is totally or partially covered, allowing, at times, the visualization of the same arrangement. The results suggest that the papillae and spores are informative and that synapomorphy may be found in some clades.

Keywords: Bryophyta, Papillae, Spores, Scanning Electron Microscopy. 


\section{Introdução}

Musgos pleurocárpicos compreendem cerca de 50\% de todos os musgos (Shaw \& Renzaglia 2004). O maior clado em número de espécies pleurocárpicas, Hypnales, com distribuição ao longo dos trópicos, apresentando cerca de 4.418 espécies ou aproximadamente $80 \%$ de todos os musgos pleurocárpicos (Buck \& Goffinet 2000).

Hypnaceae, segundo Buck (1998, 2003) é um grupo extremamente heterogêneo morfologicamente, com gêneros mal resolvidos (Hedenäs 1989), com alta diversidade de espécies, sendo considerada consistentemente polifilética (Arikawa \& Higuchi 1999; Tsubota et al. 1999; Buck et al. 2000; Arikawa \& Higuchi 2003; Gardiner et al. 2005; Cox et al. 2010; Huttunen et al. 2012). A família apresenta maior diversidade e distribuição na região neotropical, com cerca de 21 gêneros e 70 espécies reconhecidas somente no Neotrópico (Gradstein et al. 2001). Dentro de Hypnaceae encontram-se, além de outros gêneros que possuem "células proradas", os gêneros Chryso-hypnum Hampe e Mittenothamnium Henning, compreendendo cerca de 16 e 81 espécies reportadas atualmente, respectivamente (www.tropicos.org).

Esses dois gêneros possuem várias semelhanças morfológicas, como filídios do caulídio com região alar desenvolvida ou diferenciada, base não decurrente ou inconspicuamente decurrente, filídios do caulídio lanceolados, ovalados ou ovaladoslanceolados e filídios dos ramos frequentemente complanados (Buck 1998; Sharp et al. 1994). Contudo, Chryso-hypnum pode ser caracterizado por apresentar plantas não estipitadas; caulídio regularmente à irregularmente pinado-ramificado; pseudoparáfilo filamentoso ou folhoso. Filídios do caulídio e dos ramos ovalados a ovaladolanceolados; base cordada a levemente cordada; costa curta e dupla, "célula linear prorada" em ambas as extremidades" e esporos esféricos finamente papilosos (Gradstein et al. 2001). Já as espécies de Mittenothamnium podem ser reconhecidas como plantas estipitadas, caulídio arqueado e algumas vezes ramos delgados, costa dupla e curta, pseudoparáfilos folhosos ou triangulares, células do filídio ("células lineares proradas") projetando ângulos distais, apenas na extremidade superior e esporos minuciosamente papilosos (Gradstein et al. 2001).

Dessa maneira, observa-se que esses dois gêneros sempre apresentaram semelhanças morfológicas e consequentemente dúvidas quanto as suas identificações taxonômicas. Alguns trabalhos, por exemplo, como o de Britton (1914) mostra que Chryso-hypnum já foi sinônimo de Mittenothamnium. 
Desde a descrição da família por Wilhelm Philipp Schimper (1856) diversas classificações foram feitas utilizando, principalmente, a morfologia do gametófito na separação dos táxons. Buck (1991) sugeriu que o gametófito pode exibir mais caracteres independentes do que o esporófito, os quais têm sido tradicionalmente e amplamente usados para delimitar grupos hierárquicos. Além disso, em alguns grupos já estudados, dados moleculares mostraram melhor correspondência com a morfologia do gametófito do que com caracteres esporofíticos (Gardiner et al. 2005, Hedenäs 2007, Câmara \& Kellog 2010).

Entre os caracteres do gametófio, a morfologia dos filídios tem sido uma das mais utilizadas (Câmara \& Kellog 2010), pois muitos grupos de musgos desenvolvem ornamentações nas superfícies das células dos filídios conhecidas geralmente como papilas ou mamilas. Magill (1990) afirma que papilas são "protuberâncias microscópicas sólidas associadas com espessamento da parede celular" e mamilas são "projecções ocas sem espessamento da parede, estão associadas com a extensão do lúmen celular,". O desenvolvimento, o formato, a localização e a quantidade de papilas por células são pouco visíveis sob a microscopia de luz, podendo ser, muitas vezes, mal interpretadas (Robinson 1971, Cano 1994). Um exemplo clássico disso pode ser mostrado nas papilas em "forma de C" observadas em Syntrichia ruralis (Hedw.) F. Weber \& D. Mohr, as quais Robinson (1971), ao investigá-las sob microscopia eletrônica de varredura (MEV), observou que essas papilas não ocorrem e que na verdade representam uma distorção causada pela microscopia de luz. O estudo de MEV foi fundamental para o estudo desta espécie.

A função das papilas ainda é incerta, embora muitas teorias tenham sido propostas, sendo citadas desde entre outras para o controle da luz e temperatura para adaptações a condições xerófitas, aumento da superficie do filídio, para trocas gasosas e de água e criação de vias capilares para segurar excesso de água necessário para reduzir perda de turgor da célula (Patterson 1964, Proctor 1981).

Existe, atualmente, uma denominação conhecida como "célula prorada" para algumas ornamentações encontradas nas células dos filídios em Hypnaceae (Chrysohypnum e Mittenothamnium, por exemplo) designadas assim por alguns autores como Buck (1998), Gradstein et al. (2001), Sharp et al. (1994), entre outros. Tal denominação é baseada nas observações feitas em microscopia de luz. Essas "células proradas" podem ser definidas, segundo Magill (1990) e Malcolm \& Malcolm (2000) 
como "papilas diminutas formadas pelas pontas salientes das células prosenquimatosas".

Estudos realizados utilizando a morfologia das células proradas (papilas) sob MEV (microscopia eletrônica de varredura) em Hypnaceae são escassos, sendo conhecido apenas o de Ireland (2001), onde o autor estudou a morfologia das papilas nas células dos filídios, mostrando a presença de papilas diminutas e granulares em Buckiella undulata (Hedw.) Ireland. Além deste, encontram-se estudos em outros grupos de musgos pleurocárpicos, como Sematophyllaceae Broth. (Câmara \& Kellogg 2010) e Pilotrichaceae (Duarte-Silva et al. 2013). Entretanto, observa-se que o estudo da morfologia e desenvolvimento das papilas é mais comum nos musgos acrocárpicos (Casas De Puig \& Molinas 1974, Gallego 2005, Robinson 1971, Werner et al. 2003, Mishler 1987). Nestes, encontram-se estudos realizados em Pottiaceae (Werner et al. 2003), Fissidentaceae (Belin et al. 1974) e Polytrichaceae (Ireland 1991). Tais estudos, utilizando MEV, apresentaram características taxonômicas importantes, como forma das papilas, tamanho e origem.

Com relação aos estudos do esporófito, precisamente os esporos, observa-se que o potencial da palinologia na taxonomia vegetal aumentou dramaticamente com a aplicação de microscopia eletrônica. A maioria das investigações palinológicas tem sido dirigida para estudo de pólen de plantas fanerogâmicas (Skvarla et al. 1988, Harley \& Ferguson 1990). No entanto, os esporos de musgos, mesmo com seu tamanho muito pequeno, também têm recebido a devida atenção (Brown \& Lemmon 1980, Caldeira et al. 2006, 2009, 2013, Erkara \& Savaroglu 2007).

Um dos primeiros estudos em esporos de musgos em Hypnales foi realizado por Erdtman (1957) em um trabalho no qual o autor realizou o estudo morfológico, sob microscópio de luz, de espécies de 40 famílias. Pesquisas que o seguiram tiveram como objetivo compreender a esporogênese como os de Brown \& Lemmon (1988). Os trabalhos de Caldeira et al. (2009), McClymont \& Larson (1964), Sorsa \& Koponen (1973), Savaroglu \& Erkara (2008), entre outros incluíram dados importantes acerca da morfologia de várias espécies de musgos e possibilitou a utilização de dados palinológicos em estudos de taxonomia.

Os esporos de musgos são, na maior parte das vezes, unicelulares, esféricos, sendo tipicamente formados por três camadas no esporoderma: intina, exina e perina (Mcclymont \& Larson 1964, Olesen \& Mogensen 1978, Neidhart 1979, Mogensen 1981). Essas 
informações corroboram com alguns estudos, como os de Buck (1998), Sharp et al. (1994), Gradstein et al. (2001), entre outros, que definem que os esporos encontrados em Chryso-hypnum e Mittenothamnium são esféricos ou minuciosamente papilosos. Tais observações foram feitas utilizando apenas microscopia de luz. Até o momento não há estudos de esporos nesses dois gêneros utilizando MEV.

Dessa maneira, configuram-se objetivos deste trabalho: investigar a morfologia dos esporos e o desenvolvimento das células proradas (papilas) nos filídios de Chrysohypnum e Mittenothamnium, e sua aplicabilidade na taxonomia dos grupos, buscando caracteres morfológicos informativos para os gêneros com auxílio de microscopia eletrônica de varredura.

\section{Material e Métodos}

Material examinado: Para o estudo das papilas, as espécies observadas foram Chryso-hypnum cavifolium (Dixon) Ochyra \& Sharp, Chryso-hypnum diminutivum (Hampe) W. R. Buck, Chryso-hypnum elegantulum (Hook.) Hampe, Chryso-hypnum frondosum (Mitt.) W. R. Buck, Chryso-hypnum rostratulum (Renauld \& Card.) Moura, Chryso-hypnum squarrosulum (Cardot) N. Nishim. \& Ando, Mittenothamnium reptans (Hedw.) Cardot e Mittenothamnium substriatum (Mitt.) Cardot., totalizando oito espécies e 11 espécimes, provenientes de várias regiões (Tabela 1). Para estudo dos esporos, foram observadas as espécies $C$. diminutivum, $C$. elegantulum e $M$. reptans, totalizando três espécimes (Tabela 2). A escolha de todos esses espécimes foi baseada na quantidade do material disponível para as análises.

Preparação do material. Os filídios do caulídio e dos ramos foram retirados em diferentes estágios de maturação. As amostras foram preparadas através do protocolo proposto por Bozzola \& Russel (1998). As amostras foram reidratadas em água fervente por 5 minutos e em seguida o material foi desidratado em uma série alcoólica de diferentes concentrações $(50 \%, 55 \%, 60 \%, 65 \%, 70 \%, 75 \%, 80 \%, 85 \%, 90 \%, 95 \%$, $100 \%, 100 \%$ e 100\%), trocando a concentração a cada duas horas. Após a desidratação total, os espécimes foram secos através da técnica de dessecação a ponto crítico, usando Deton vacuum LLC CPD - 1 e Balzers 030 CPD, utilizando o dióxido de carbono como fluído de transição. Em seguida, o material foi montado em "stubs" para ser metalizado e coberto com uma camada de ouro ou ouro e paládio, usando para tal os metalizadores 
Hummer 6.2 e Balzers 050 SCD e mantidos em um recipiente, contendo sílica em gel, para que permanecessem secas até o momento da observação sob MEV. Os espécimes foram observados e micrografados utilizando JSM - 840 A SM e JSM - 5410 LV, sob $15 \mathrm{kV}$ e "working distance" de $10 \mathrm{~mm}$. Todo processo de preparação das amostras, ponto crítico, metalização e observação no microscópio eletrônico de varredura foi realizado no Departamento de Biologia Molecular da Universidade de Brasília, Distrito Federal.

Para os esporos, as amostras foram montadas diretamente nos "stubs" para em seguida serem metalizadas e cobertas com uma camada de ouro ou ouro e paládio usando para tal os metalizadores Hummer 6.2 e Balzers 050 SCD. Finalmente, os espécimes foram observados e micrografados utilizando JSM - 840 A SM e JSM $5410 \mathrm{LV}$, sob $15 \mathrm{kV}$ e "working distance" de $10 \mathrm{~mm}$. Após as análises, os esporos foram descritos utilizando-se a nomenclatura palinológica de Punt et al. (2007), com adaptações para briófitas de Luizi-Ponzo e Barth (1998).

\section{Resultados}

Papilas. Através de MEV, observou-se estruturas semelhantes a papilas em todos os espécimes estudados. Assim, os autores optaram em corroborar com Magill (1990) e chamar de papilas as estruturas das células ao invés de "células proradas", tendo em vista que a definição de papila citada por Magill (1990) corresponde mais com as características observadas pelos autores.

Todos os espécimes estudados apresentaram papilas na face abaxial dos filídios e poucas papilas ou nenhuma na face adaxial, principalmente na região basal do filídio. Observou-se que o desenvolvimento das papilas ao longo da lâmina do filídio é basípeto, onde as papilas da região apical do filídio apresentam um estágio mais maduro de desenvolvimento quando comparadas com as papilas da região basal.

Os táxons com mais de uma papila por célula (pluripapilosos) apresentaram células com o comprimento pelo menos nove vezes maior que a largura, enquanto que os táxons com apenas uma papila por célula (unipapilosos) apresentaram células lineares muito longas, cerca de 15 vezes maior que a largura. 
Foi encontrado apenas um tipo de papila em Chryso-hypnum e Mittenothamnium, denominada aqui de papila cônica, descrita por Câmara \& Kellogg (2010). Podem ser divididas de duas formas, de acordo com a morfologia e estágio de desenvolvimento: madura e imatura (Fig. 1).

A maioria das papilas nesses dois gêneros apresentou um padrão de desenvolvimento em que não há alteração na sua forma até atingir a maturidade, sendo observado apenas crescimento contínuo (Câmara \& Kellog 2010) na altura das papilas (Fig. 2). As papilas aparecem no início do desenvolvimento do filídio, e estão sempre presentes nos filídios jovens e maduros examinados.

Papila cônica. São papilas simples, mais ou menos em forma de cone (Fig. 1), com ápices que são geralmente redondos e lisos, descritas por Câmara \& Kellogg (2010) para Sematophyllaceae. Ainda, segundo estes autores, as papilas surgem como pequenas protuberâncias da parede celular e crescem continuamente até atingirem a maturidade o que pode ser observado nesse estudo (Fig. 1). Papilas jovens apresentam o mesmo diâmetro $(1 \mu \mathrm{m})$ de papilas adultas, mas se projetam menos na superfície da célula (Fig. 3). Podem apresentar altura de aproximadamente 3-4 $\mu \mathrm{m}$. As papilas cônicas foram encontradas em todos os táxons investigados. Porém, Chryso-hypnum apresentou duas papilas por célula, sendo uma no ápice e a outra na base e Mittenothamnium apresentou apenas uma papila por célula, sendo esta observada no ápice.

Esporos. A análise dos esporos em MEV permitiu uma observação detalhada da morfologia do mesmo, pois devido ao tamanho reduzido dos esporos estudados, o estudo sob microscopia de luz mostrou-se insuficiente para descrever a ornamentação corretamente.

As três espécies da família Hypnaceae estudadas aqui apresentam esporos considerados de tamanho pequeno, com medias de diâmetro de 10-12 $\mu$ m (Erdtman 1960). A ornamentação observada em todas as espécies estudadas é granulada, apresentando, entretanto, variações no tamanho e na disposição dos grânulos (Fig. 4), de forma que dois padrões distintos foram observados: Chryso-hypnum diminutivum e $C$. elegantulum apresentaram esporos de tamanho pequeno $(10 \mu \mathrm{m})$, âmbito subcircular e ornamentação com grânulos de tamanho variável, formados pela fusão de nanogrânulos 
(Fig. 5). Os grânulos estão dispostos de maneira densa sobre a superfície do esporo, cobrindo toda a exina. Em Mittenothamnium observou-se que os esporos também apresentam tamanho pequeno $(10-12 \mu \mathrm{m})$, âmbito subcircular, e que a disposição dos grânulos na superfície da parede se dá de forma esparsa e irregular (Fig. 6), onde a exina apresenta-se total ou parcialmente coberta, permitindo, algumas vezes, a visualização da mesma.

\section{Discussão}

Papilas. Em Chryso-hypnum e Mittenothamnium quando as paredes celulares se colapsam devido à preparação do material, as papilas continuam proeminentes, sugerindo o uso adequado do termo "papila" para se referir a tais estruturas, o que não acontece em algumas espécies de Sematophyllaceae, por exemplo, nas quais as papilas são na realidade mamilas (Câmara \& Kellog 2010), de acordo com a clássica definição de Magill (1990). Isso sugere que as papilas nos gêneros aqui estudados são sólidas e não ocas.

A presença de papilas na face abaxial e, poucas ou raras na adaxial dos filídios também foi observada em Pottiaceae (Mishler 1987) e Hypnaceae (Ireland 2001). Contudo, neste último trabalho foi mostrada a presença de papilas cuticulares em toda extensão da célula. Porém, difere do observado em Sematophyllaceae, Fissidentaceae e Pilotrichaceae (Câmara \& Kellog 2010, Belin et al. 1974, Duarte-Silva et al. 2013), os quais as papilas se apresentam apenas na face abaxial.

Estudos anteriores sobre papilas, realizados com auxilio de MEV, são mais restritos aos musgos acrocárpicos (Gallego 2005, Guerra et al. 1992, Magill 1977, Robinson, 1971, Werner et al. 2003) do que aos pleurocárpicos (Duarte-Silva 2013, Câmara \& Kellog 2010, Brown \& Lemmon 1980, Caldeira et al. 2009). Particularmente em Pottiaceae, cujas papilas são geralmente mais elaboradas, três vezes maiores e ramificadas (Câmara \& Kellogg 2010). Papilas das espécies de Syntrichia (Pottiaceae) foram estudadas em detalhe por Gallego (2005), observando-se que os filídios apresentam células unipapilosas ou pluripapilosas com 1-12 papilas por célula. Essas papilas encontram-se em uma ou ambas as faces do filídio, dependendo da espécie.

Assim, as papilas encontradas em Chryso-hypnum e Mittenothamnium são muito simples quando comparadas com as grandes e ramificadas em Pottiaceae. Todavia, 
ocorrem algumas semelhanças entre Syntrichia (Pottiaceae) e os gêneros aqui estudados: como a presença de papilas em forma cônica, e a presença em uma ou ambas as faces. Além disso, pode-se observar também que as papilas em Chryso-hypnum e Mittenothamnium são semelhantes, no formato, com as papilas cônicas de Trichosteleum singapurense (Sematophyllaceae).

As papilas cônicas, quando jovens, apresentam o mesmo diâmetro quando comparadas com as papilas adultas (Fig. 3), diferindo apenas na altura (Fig. 2). Com MEV foram observados dois tipos de papilas nas células dos filídios: em Mittenothamnium observou-se apenas uma única papila na célula, na extremidade superior no ápice e nas espécies de Chryso-hypnum foram observadas duas papilas por célula em ambas as extremidades da célula (ápice e base), tanto em desenvolvimento quanto na morfologia adulta. Essas informações corroboram com Nishimura e Ando (1986) que, revisando algumas espécies de Mittenothamnium, observaram características morfológicas relacionadas às células dos filídios, onde para Chrysohypnum definiram "células proradas" como células laminares com projeções em ambas as extremidades; e para Mittenothamnium as células foram definidas como tendo projeções somente em extremidades superiores.

Observou-se, que todas as espécies de Chryso-hypnum (C. cavifolium, C. diminutivum, C. elegantulum, C. frondosum, C. rostratulum e C. squarrosulum) apresentam a mesma disposição das papilas nas células dos filídios, ou seja, papila na base e no ápice da mesma célula (Figs. 7-8). Todas as espécies de Chryso-hypnum apresentaram papilas bem evidentes na parte abaxial, tanto na base, quanto na costa (Fig. 9) e no ápice. Já na face adaxial, as papilas apresentaram-se inexistentes em algumas espécies (Fig. 10) ou pouco evidentes a quase imperceptíveis em outras, como em C. elegantulum. A ornamentação das papilas em C. cavifolium foi a mais diferenciada, pois essa espécie apresentou papilas maiores em comprimento e o ápice da papila mais comprido e acuminado (Fig. 11), quando comparado as outras espécies de Chryso-hypnum.

Contudo, a disposição das papilas em Mittenothamnium reptans (Fig. 12) e $M$. substriatum é diferente, apresentando células mais alongadas com uma única papila somente no ápice. Na porção adaxial do filídio não há papilas, enquanto que na parte abaxial a presença é bem evidente. 
Essas informações corroboram com Câmara \& Kellogg (2010) quando afirmam que as papilas surgem como pequenas protuberâncias da parede celular e crescem até atingirem a maturidade. As papilas jovens (imaturas) apresentam o mesmo diâmetro das papilas adultas, mas se projetam menos na superfície da célula.

Esporos. Apesar de todos os esporos estudados terem apresentado tamanho pequeno $(10-12 \mu \mathrm{m})$, foram observadas variações que permitem distinguir os esporos das diferentes espécies. A ornamentação encontrada em Chryso-hypnum e Mittenothamnium foi também encontrada e descrita para espécies da família Sematophyllaceae no trabalho de Caldeira et al. (2009), sendo as estruturas formadas pela associação de nanogrânulos denominadas "rosetas" pelas autoras. Alfayate et al. (2013) também identificaram esse mesmo tipo de ornamentação para espécies da família Neckeraceae, denominando-o "agregados de grânulos". No presente estudo, a nomenclatura seguiu a definição de Alfayate et al. (2013). A predominância desse tipo de ornamentação encontrada nos esporos de Chryso-hypnum e Mittenothamnium apresentadas aqui e nos esporos de espécies de Hypnales, e em outras literaturas (Caldeira et al. 2009, Alfayate et al. 2013), indicam uma maior representatividade deste padrão de ornamentação (grânulos de tamanho variável, formados pela associação de grânulos menores) nesses esporos.

\section{Conclusão}

O presente estudo mostrou que as papilas podem ser informativas apresentandose como mais uma ferramenta morfológica para a diferenciação desses dois gêneros. Além disso, a correlação entre o tamanho das células dos filídios e a morfologia das papilas pode sugerir que a formação da parede celular conduza para as diferenças observadas na forma. Portanto, seria de interesse em estudos futuros, observar a dinâmica do desenvolvimento dos filídios nas espécies de Chryso-hypnum e Mittenothamnium para determinar se o desenvolvimento das papilas está relacionado com a formação da parede celular.

Já os esporos aqui estudados, principalmente sob microscopia eletrônica de varredura, apresentam ornamentações semelhantes: os elementos são grânulos e nanogrânulos. Contudo, o padrão e disposição destes elementos é o que confere as diferenças entre eles, corroborando assim com os dados encontrados em outras análises 
de Palinologia de espécies pertencentes à Hypnales. E o padrão de ornamentação representado por grânulos formados pela associação de nanogrânulos apresenta-se como padrão preferencial na ornamentação da perina das espécies analisadas no presente estudo.

\section{Agradecimentos}

Os autores agradecem aos curadores dos herbários visitados e pelos empréstimos concedidos: Dr. Bruce Allen (MO), Dra. Barbara Thiers (NY), José Marcos Nunes (ALCB) e Marlene Barbosa (UFP). Ao laboratório de Microscopia Eletrônica da Universidade de Brasília e ao Grupo de Fadiga, Fratura e Materiais (GFFM) pela estrutura concedida para as análises de MEV. E a Instituição de fomento de aperfeiçoamento de pessoal de nível superior (CAPES), pela bolsa concedida.

\section{Referência Bibliográfica}

Alfayate, C.; E. Ron, B. Estébanez, M. A. Pérez-Batista. 2013. Mature spores of four pleurocarpous mosses in the Canary Islands: ultrastructure and early germination stages. The Bryologist 2: 97-112.

Arikawa, T. \& M. Higuchi. 1999. Phylogenetic analysis of the Plagiotheciaceae (Musci) and its relatives based on $r b c L$ gene sequences. Cryptogamie, Bryologie 20: 231-245. Arikawa, T. \& M. Higuchi. 2003. Preliminary phylogenetic analysis of Pylaisia (Hypnaceae, Musci) and its relatives based on $r b c L$ gene sequences. Journal of the Hattori Botanical Laboratory 94: 87-106.

Belin, J. M., M. Bizot \& Dury. M. N. 1974. Le tissue foliaire chez les Fissidens. Société Botanique de France, Colloque Bryologie 121: 111-116.

Bozzola, J. J. \& L. D. Russel. 1998. Electron Microscopy. Principles and Techniques for biologists. $2^{\text {nd }}$ edition. Jones \& Bartlett, Sudbury, Massachusetts.

Britton, E. G. 1914. Notes on Nomenclature. XII. The Bryologist. 17: 1-10. 
Brown, R. C. \& B. E. Lemmon. 1980. Ultrastructural Aspects of Chloroplast Development in Spores of the Moss Leptodictyum riparium (Hedw.) Warnst. The Bryologist 83: 545-554.

Brown, R. C. \& B. E. Lemmon. 1988. Sporogenesis in Bryophytes. Advances in Bryology 3: 159-223.

Buck, W. R. 1991. The basis for familial classification of pleurocarpous mosses. Advances in Bryology 4:146-185.

Buck, W. R. 1998. Pleurocarpous Mosses of West Indies. Memoirs of the New York Botanical Garden 82: 1-400.

Buck, W. R. 2003. Guide to the Plants of Central French Guiana. Part 3. Mosses. Memoirs of the New York Botanical Garden 76: 1-167.

Buck, W. R. \& B. Goffinet. 2000. Morphology and classification of mosses. Pages 71123. In A. J. Shaw \& B. Goffinet, Bryophyte Biology. Cambridge University Press, Cambridge.

Buck, W. R., B. Goffinet \& A. J. Shaw. 2000. Testing morphological concepts of orders of pleurocarpous mosses (Bryophyta) using phylogenetic reconstructions based on trnL-trnF and rps4 sequences. Molecular Phylogenetic Evolution 16: 180198.

Caldeira, I. C., V. G. L. Esteves \& A. P. Luizi-Ponzo. 2006. Morfologia dos esporos das espécies de Leucobryaceae Schimp. (Bryophyta) do Parque Estadual de Ilha Grande, Município de Angra dos Reis, Estado do Rio de Janeiro. Revista Brasileira Botânica 29: 301-307.

Caldeira, I. C., V. G. L. Esteves \& A. P. Luizi-Ponzo. 2009. Morfologia dos esporos de Sematophyllaceae Broth., ocorrentes em três fragmentos de Mata Atlântica, no Rio de Janeiro, Brasil. Revista Brasileira Botânica 32: 299-306.

Caldeira, I. C., A. P. Luizi-Ponzo \& V. G. L. Esteves. 2013. Palynology of selected species of Fissidens (Hedw.). Plant Systematic Evolution 299:187-195.

Câmara, P. E. A. S. \& E. A. Kellog. 2010. Morphology and development of leaf papillae in Sematophyllaceae. The Bryologist 113: 22-33. 
Cano, M. J. 1994. Importáncia de la microscopia eletronica en los studios taxonomicos de briófitos. Boletin de La Sociedad Española de Briologia 4: 1-3.

Casas De Puig, C. \& L. Molinas. 1974. Etude au microscope életronique à balayage de la surface des feuilles de Tortula muralis (Hedw.) Gaertn. var. hirsuta (Vent.) Par. Revue Bryologique et Lichénologique 40: 267-270.

Cox, C. J., B. Goffinet, N. S. Wickett, S. Boles \& J. Shaw. 2010. Moss diversity: A molecular phylogenetics analysis of genera. Phytotaxa 9: 175-195.

Duarte-silva, A. G., M. Carvalho-Silva \& P. E. A. S. Câmara. 2013. Morphology and development of leaf papillae in the Pilotrichaceae. Acta Botanica Brasilica 27: 737742.

Erdtman, G. 1957. Pollen and spore morphology/plant taxonomy - Gymnospermae, Pteridophyta, Bryophyta (Illustrations) (An introduction to palynology. II). Estocolmo: Almqvist \& Wiksell/Gebers Förlag AB, 151pp.

Erdtman, G. 1960. The acetolysis method. A revised description. Svensk Botanisk Tidskrift. 39: 561-564.

Erkara, I. P. \& F. Savaroglu. 2007. Spore morphology of some Brachytheciaceae

Schimp. Species (Bryophyta) from Turkey. Nordic Journal of Botany 25:194-198.

Gallego, M. T. 2005. A taxonomic study of the genus Syntrichia. Journal of the Hattori Botanical Laboratory 98: 47-122.

Gardiner, A., M. Ignatov, S. Huttunen \& A. Troitsky. 2005. On resurrection of the families Pseudoleskeacae Schimp. And Pylaisiaceae Schimp. (Musci, Hypnales). Taxon 54: 651-663.

Gradstein, S. R., S. P. Churchill \& N. Salazar-Allen. 2001. Guide to the Bryophytes of Tropical America. Memoirs of the New York Botanical Garden 86: 1-577.

Guerra, J., R. M. Ros \& J. S. Carrion. 1992. The taxonomic status of Tortula muralis var. baetica (Musci, Pottiaceae) a comparative study. Journal of Bryology 17: 275283.

Harley, M. \& I. K. Ferguson. 1990. The role of the SEM in pollen morphology and plant systematics. - In: Claugher, D. (ed.) Scanning electron microscopy in taxonomy and functional microscopy $41: 45-68$

Hedenäs, L. 1989. Some neglected character distribution patterns among the pleurocarpous mosses. Bryologist. 92: 157-163. 
Hedenäs, L. 2007. Morphological characters and their use in pleurocarpous moss systematics. The systematic association special 71: 227-245.

Huttunen, S., N. Bell, V. K. Bobrova, V. Buchbender, W. R. Buck, C. J. Cox, B. Goffinet, L. Hedenäs, B. C. Ho, M. Ignatov, M. Krug, O. Kuznetsova, I. Milyutina, A. Newton, S. Olsson, L. Pokorny, A. J. Shaw, M. Stech, A. Troitsky, A. Vanderpoorten, and D. Quandt. 2012. Disentangling knots of rapid evolution: origin and diversification of the moss order Hypnales. Journal of Bryology 34:187-202.

Ireland, R. R. 1991. Cuticular papillae of Atrichum crispum. The Bryologist 94: 73-76.

Ireland, R. R. 2001. Buckiella, a new genus in the Hypnaceae. Smithsonian Institution, Department of Botany, Novon 11: 55-62.

Luizi-Ponzo, A. P., M. O. Barth. 1998. Spore morphology of some Bruchiaceae species (Bryophyta) from Brazil. Grana 37: 222-227.

Magill, R. E. 1977. A reexamination of Globulinella (Musci; Pottiaceae). The Bryologist 80: 76-82.

Magill, R. E. 1990. Glossarium Polyglottum Bryologiae. Monographs in systematic botany from the Missouri Botanical Garden 33:1-50.

Malcolm, B. \& Malcolm, N. 2000. Mosses and other bryophytes an illustrated glossary. Micro-optics press, 220pp.

Mcclymont, J. W. D. A. Larson. 1964. An electron-microscope study of spore wall structure in the Musci. American Journal of Botany 51: 195-200.

Mishler, B. D.1987. Leaf development in Tortula papillosissima (Pottiaceae). Memoirs of the New York Botanical Garden 45: 48-54.

Mogensen, G. S. 1981. The Biological Significance of Morphological Characters in Bryophytes: The Spore. The Bryologist 84: 187-207.

Neidhart, H. B. Comparative studies of Sporogenesis in bryophytes. In: Clarke, G. C. S.; Duckett, J. G. (Org.) Bryophyte Systematics. London: Academic Press, 1979. p. 251-280.

Nishimura, N. \& H. Ando. 1986. A Revision of Some Mittenothamnium Species Described from Mexico. The Bryologist 89: 66-69.

Olesen, P \& G. S. Mogensen,. 1978. Ultrastructure, Histochemistry and Notes on Germination Stages of Spores in Selected Mosses. The Bryologist 81: 493-516,

Patterson, P. M. 1964. Problems presented by bryophytic xerophytism. The Bryologist 67: 390-396. 
Proctor, M. C. F. 1981. Physiological ecology of bryophytes. Advances in Bryology 1: 79-166.

Punt, W., S. Nilson, S. Blackmore, A. Le Thomas. 2007. Glossary of pollen and spore terminology. Review of Palaeobotany and Palynology 143: 1-81,

Robison, H. 1971. Scanning electron microscope studies on moss leaves and peristomes. The Bryologist 74: 473-483.

Sharp, A. J., H. A. Crum, \& P. Eckel. 1994. The Moss Flora of Mexico, Memoirs of The New York Botanical Garden 69:1-1113.

Skvarla, J. J., J. R. Rowley \& W. F. Chissoe. 1988. Adaptability of scanning electron microscopy to studies of pollen morphology. - Aliso 12: 119-175.

Savaroglu, F., I. P. Erkara. 2008. Observations of spore morphology of some Pottiaceae Schimp. species (Bryophyta) in Turkey. Plant Syst. Evol. 271: 93-99.

Schimper, W. P. 1856. Corollarium Bryologiae Europaeae. E. Schweizerbart, Stuttgart, 113:1-140.

Shaw, A. J. \& K. Renzaglia. 2004. Phylogeny and diversification of bryophytes. American Journal of Botany 91: 1557-1581.

Sorsa, P., \& T. Koponem. 1973. Spore morphology of Mniaceae Mitt. (Bryophyta) and its taxonomy significance. Ann. Bot. Fenniei 10: 187-200.

Tsubota, H., N. Nakao, H. Akiyama, T. Yamaguchi, M. Higuchi, H. Deguchi \& T. Seki. 1999. A preliminary phylogeny of Hypnales (Musci) as inferred from chloroplast rbcL sequence data. Bryological Research 7: 233-48.

Tropicos. Tropicos.org. Missouri Botanical Garden. http://www.tropicos.org. (acesso 2016).

Werner, O., R. M. Ros \& J. M. González-Mancebo. 2003. The variability of papillae on the laminal cells of Barbula indica (Hook) Spreng. (Pottiaceae: Musci): a morphological and molecular approach. Cryptogamie, Bryologie 24: 367-375. 
ANEXO 1 - FIGURAS 

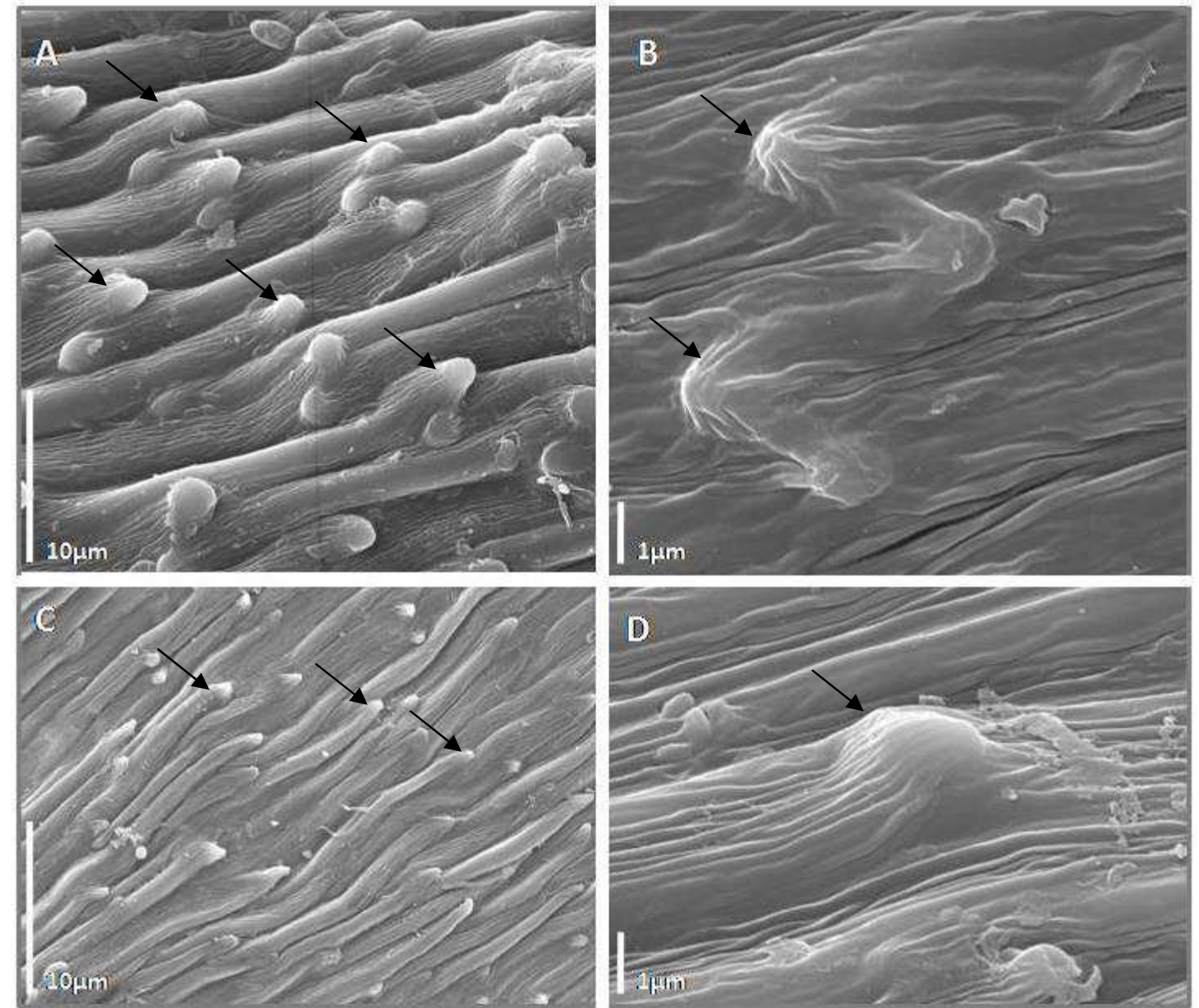

Figura 1. A-B. Face abaxial dos filídios. Chryso-hypnum diminutivum. A. Papilas maduras (setas) B. Papilas imaturas (setas). C. Mittenothamnium reptans com papilas maduras (setas). D. M. substriatum com papilas imaturas (seta). 

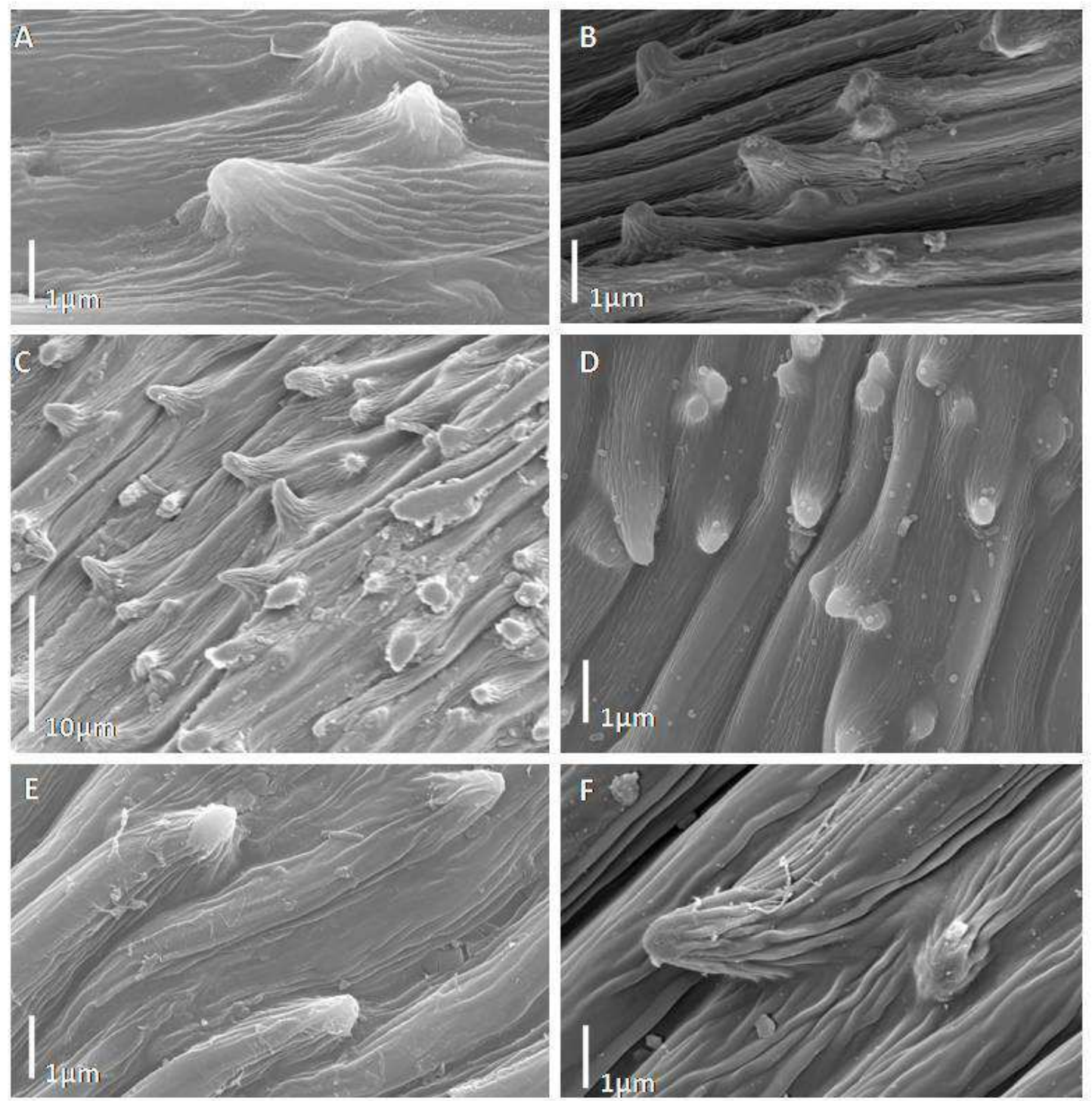

Figura 2. A-D. Face abaxial dos filídios. Comprimento das papilas em Chrysohypnum. A. Chryso-hypnum diminutivum B. Chryso-hypnum squarrosulum C. Chryso-hypnum cavifolium D. Chryso-hypnum frondosum. E-F. Comprimento das papilas em Mittenothamnium reptans. 

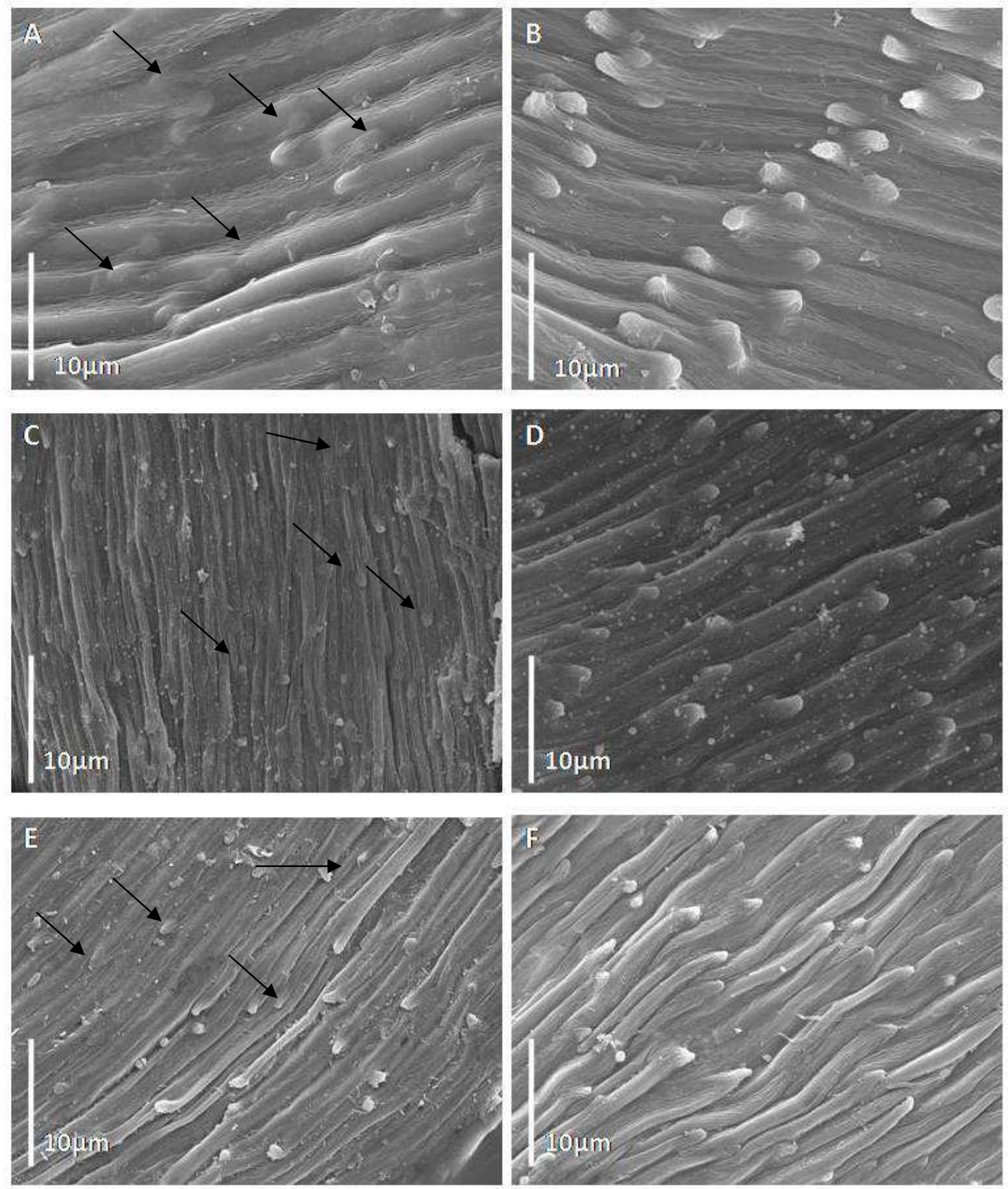

Figura 3. A-B. Face abaxial do filídio. Chryso-hypnum elegantulum. A. Papilas com menor projeção no filídio (setas) B. Papilas maduras mostrando o mesmo diâmetro das papilas jovens. C-D. Chryso-hypnum squarrosulum. C. Papilas se projetando menos no filídio (setas) D. Papilas maduras mostrando o mesmo diâmetro das papilas jovens. E-F. Mittenothamnium reptans. E. Papilas se projetando menos no filídio (setas). F. Papilas maduras mostrando mesmo diâmetro das papilas jovens. 

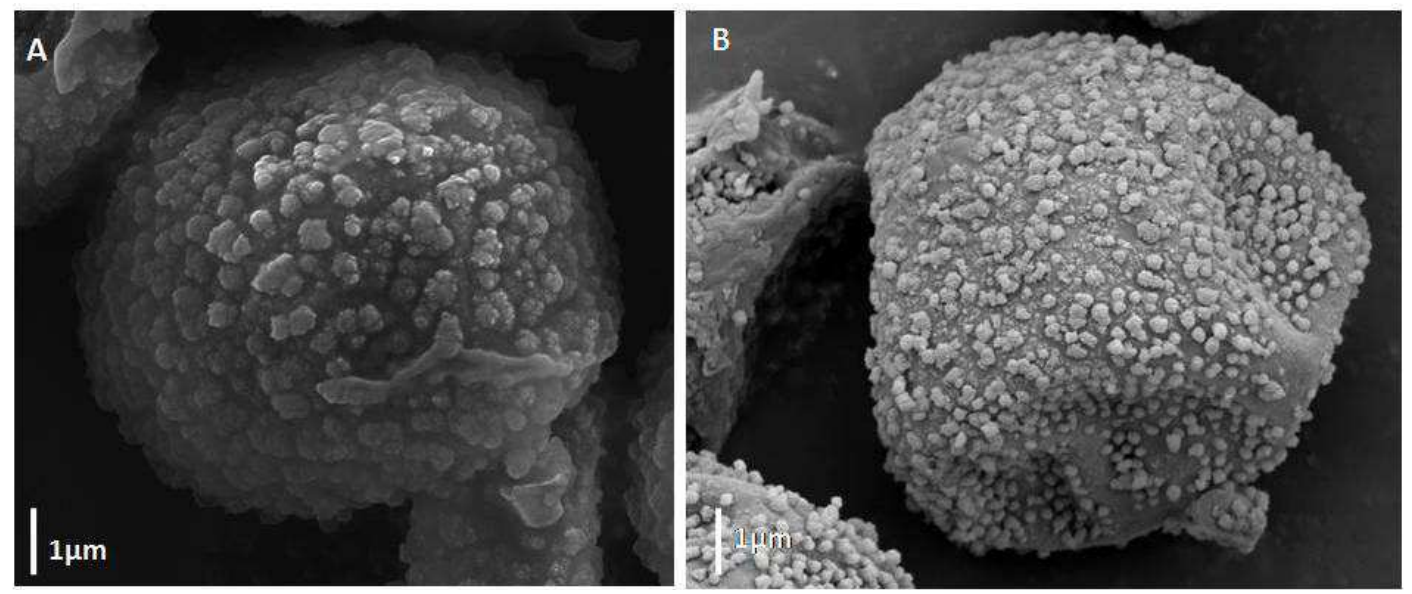

Figura 4. A-B. Esporos apresentando ornamentações em grânulos. A. Chryso-hypnum elegantulum. B. Mittenothamnium reptans.
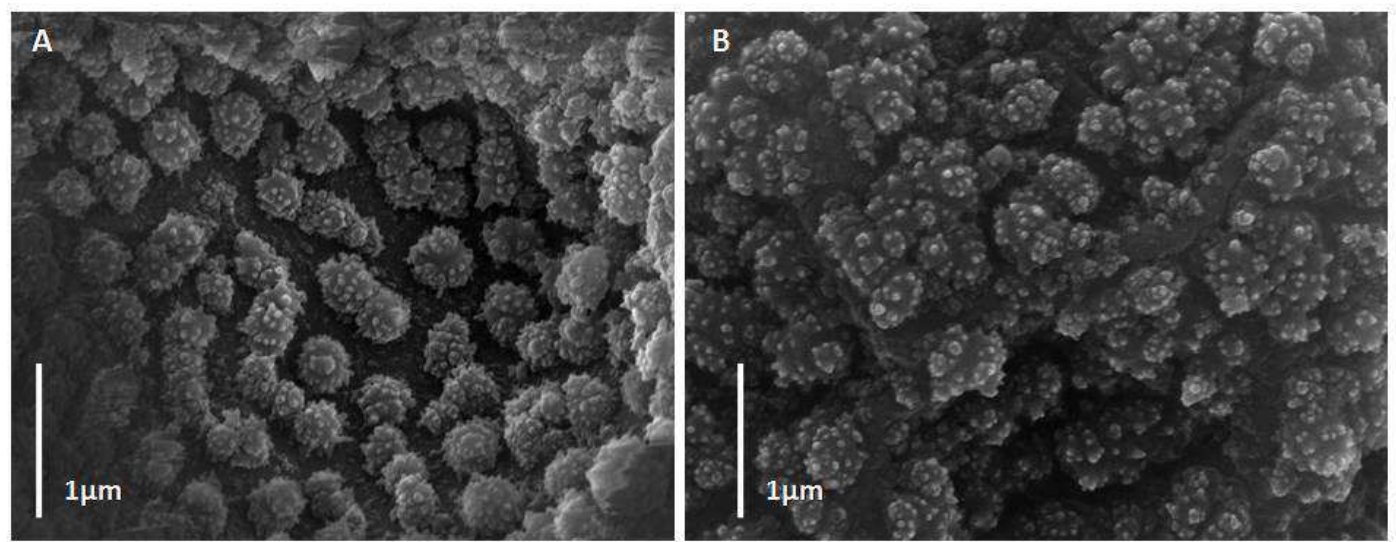

Figura 5. A-B. Chryso-hypnum elegantulum. A. Ornamentações com grânulos individualizados no esporo B. Ornamentações com grânulos fundidos irregularmente, formando ínsulas maiores cobertas por nanogrânulos.
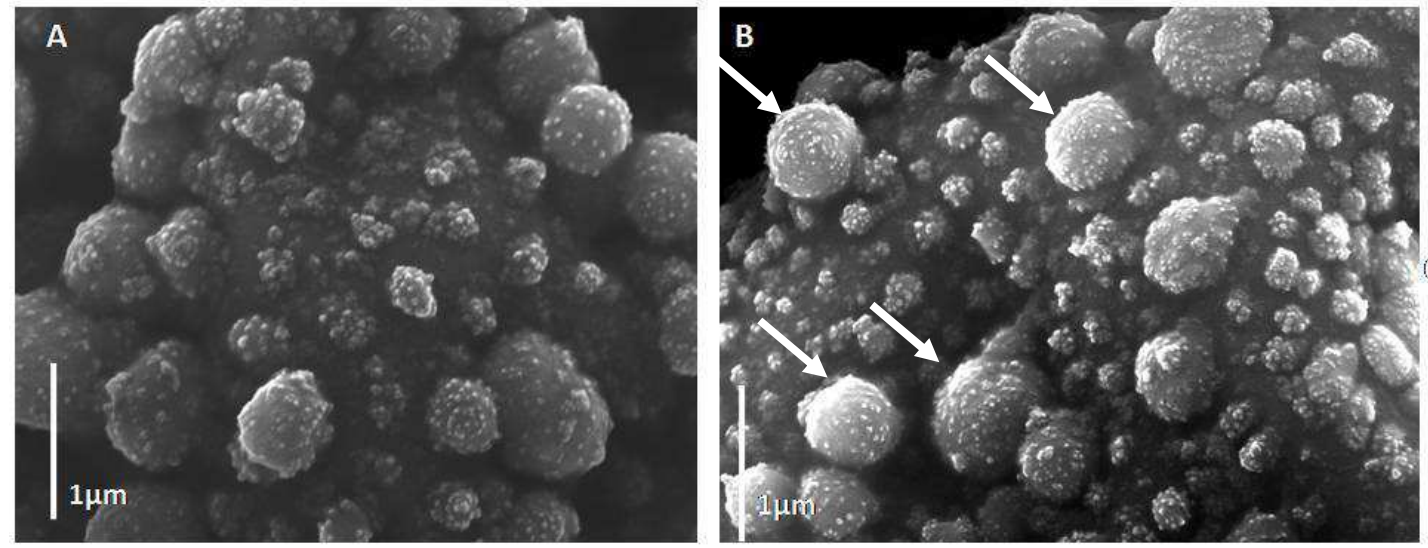

Figura 6. A-B. Mittenothamnium reptans. A. Grânulos na superfície da parede mostrando parcialmente a exina B. Os grânulos na superfície da parede são 75 distribuídos de forma esparsa e irregular formando nanogrânulos frequentemente fundidos (setas). 

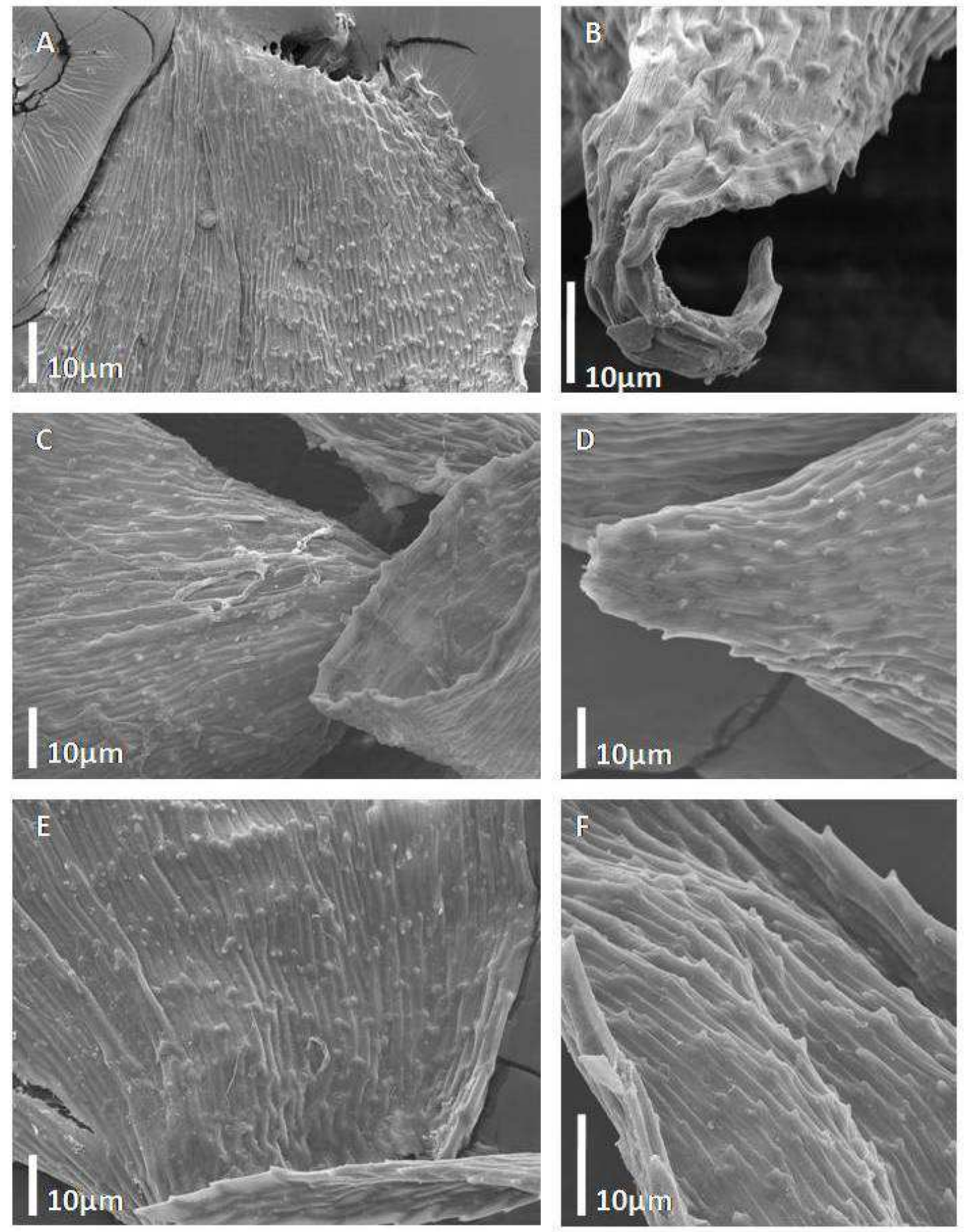

Figura 7. A-B. Face abaxial do filídio. Chryso-hypnum cavifolium. A. Base do filídio mostrando a disposição das papilas B. Ápice do filidio mostrando as papilas. C-D. Chryso-hypnum diminutivum. C. Base do filídio mostrando a disposição das papilas D. Ápice do filídio mostrando as papilas. E-F. Chryso-hypnum elegantulum. E. Base do filídio mostrando a disposição das papilas F. ápice dos filídios mostrando as papilas. 

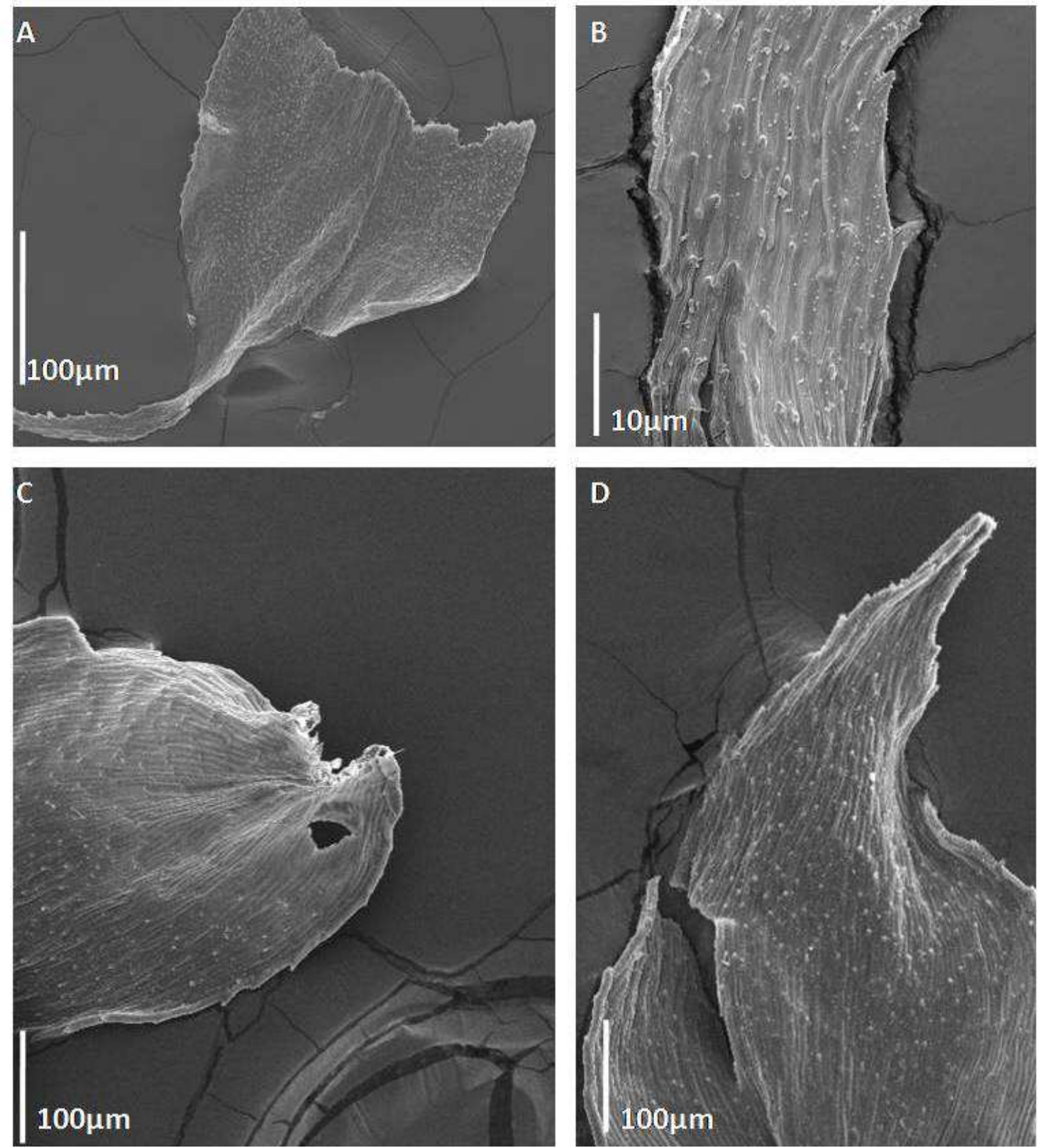

Figura 8. A-B. Face abaxial do filídio. Chryso-hypnum frondosum. A. Filídio do caulídio mostrando papilas em toda lâmina B. Ápice do filídio mostrando a presença das papilas. C-D. Chryso-hypnum squarrosulum. C. Base do filídio mostrando menor presença de papilas D. Ápice do filídio apresentando as papilas. 

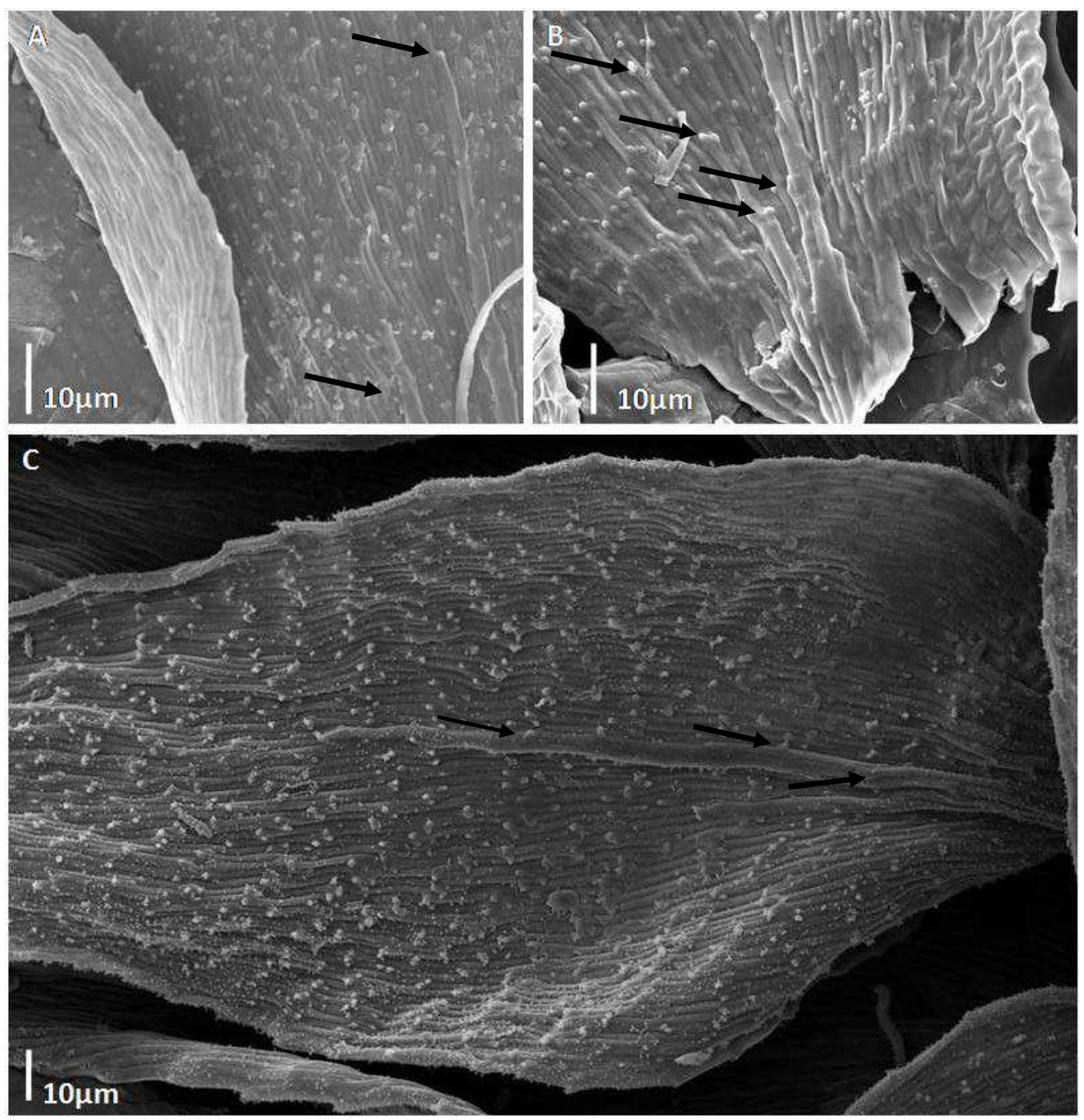

Figura 9. A-C. face abaxial do filídio. Papilas presentes na costa (setas) dos filídios. A. Chryso-hypnum elegantulum B. Chryso-hypnum diminutivum C. Chryso-hypnum rostratulum 

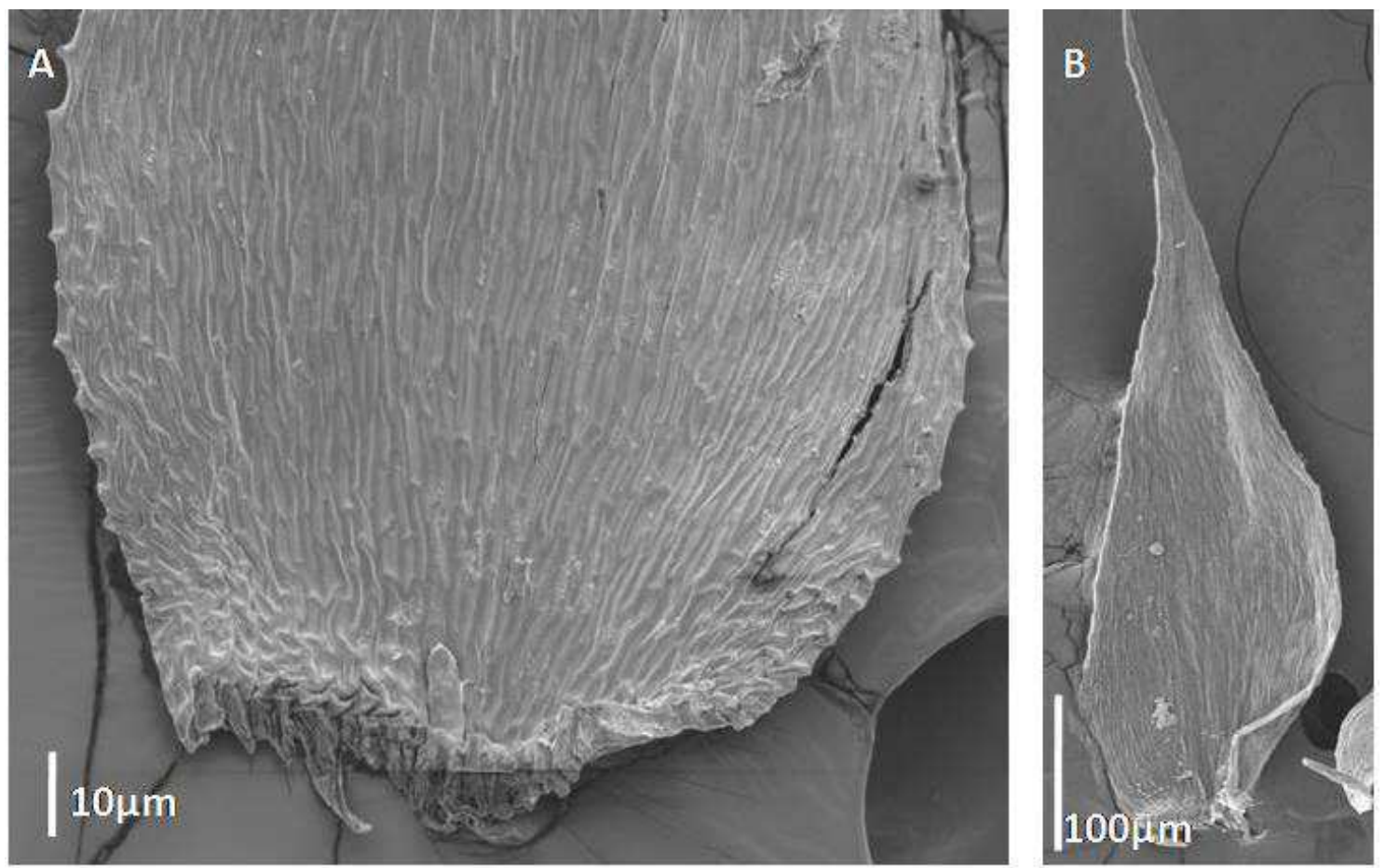

Figura 10. A-B. Face adaxial do filídio. Chryso-hypnum diminutivum. A. Base do filídio sem papilas. B. Filídio inteiro sem papilas.
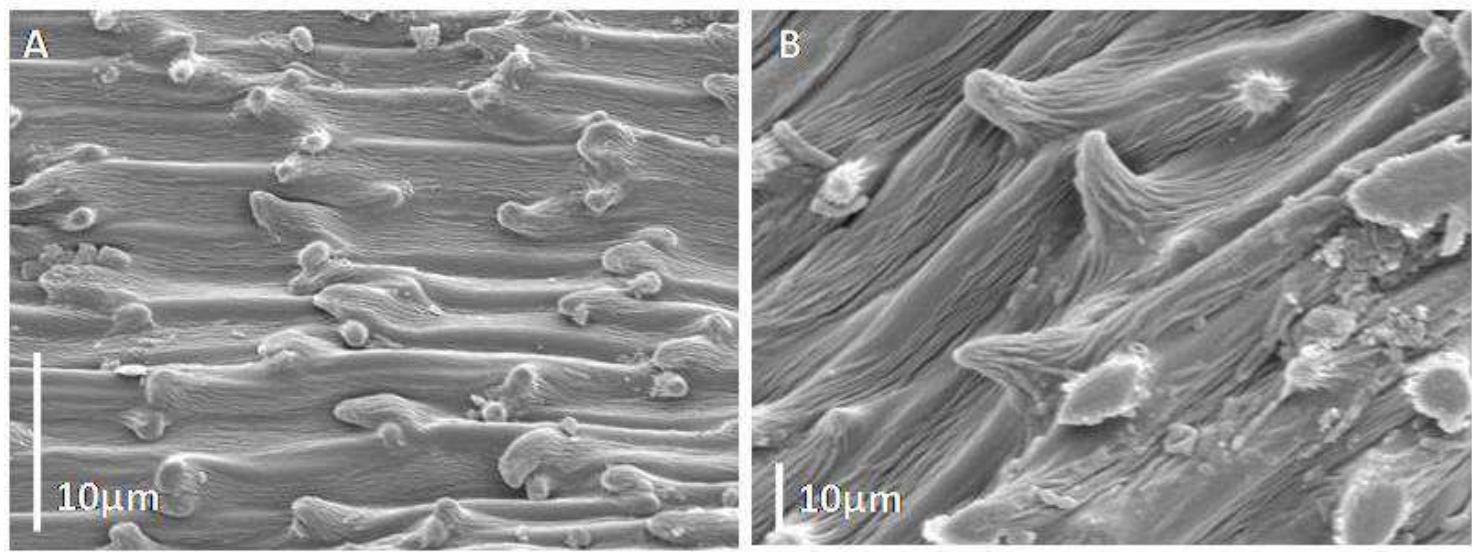

Figura 11. A-B. Chryso-hypnum cavifolium. A. Disposição das papilas em ambas as extremidades da célula B. Papilas mais compridas e mais acuminadas. 

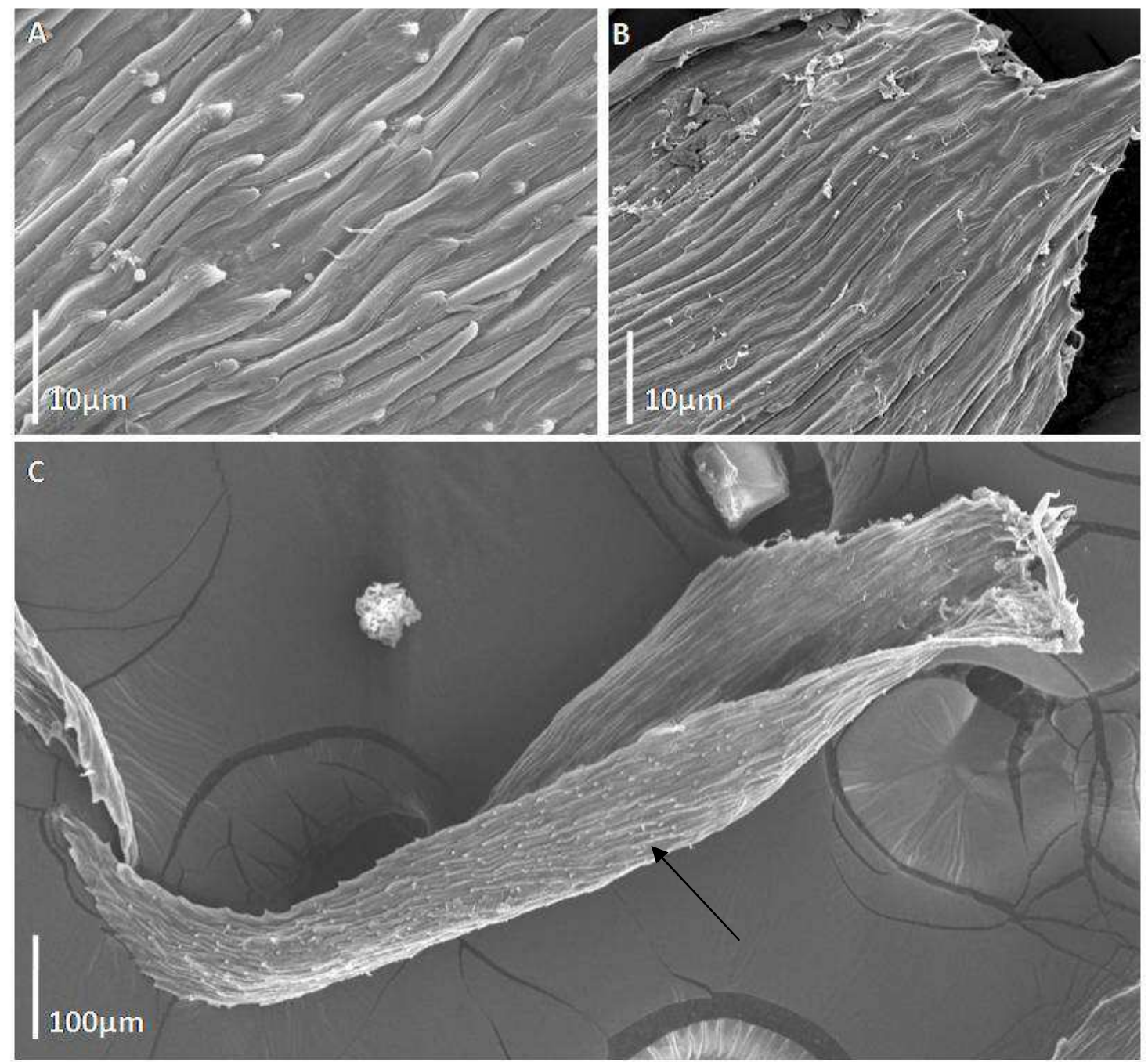

Figura 12. A-C. Mittenothamnium reptans. A. Face abaxial do filídio mostrando a presença das papilas B. Face adaxial dos filídios sem papilas C. Filídio inteiro mostrando a presença das papilas na face abaxial (seta). 
ANEXO 2- TABELAS 
Tabela 1. Informações do Voucher das amostras realizada a Microscopia Eletrônica de Varredura (MEV) nos filídios.

\begin{tabular}{ccc}
\hline Espécie & Coletor, número, herbário & Local \\
\hline Chryso-hypnum cavifolium & Townsend, 158(NY) & Quênia \\
Chryso-hypnum diminutivum & Pôrto, 23753 (UFP) & Pernambuco \\
Chryso-hypnum diminutivum & Breitenbach, 346 (NY) & África \\
Chryso-hypnum elegantulum & Pereira-Silva, 6281 (ALCB) & Goiás \\
Chryso-hypnum frondosum & Frey \& Kürschner, 6987(NY) & Zaire \\
Chryso-hypnum rostratulum & Magill, 14286 (MO) & Nicarágua \\
Chryso-hypnum squarrosulum & Allen, 8796 (NY) & Panamá \\
Mittenothamnium substriatum & Bastos, 5117 (ALCB) & Salvador \\
Mittenothamnium reptans & Penha, 551 (ALCB) & Espírito Santo \\
Mittenothamnium reptans & Allen, 23435 (MO) & Suriname \\
Mittenothamnium reptans & Wasum et al., s.n., (ALCB) & Rio Grande do Sul \\
\hline
\end{tabular}

Tabela 2. Informações do Voucher das amostras realizada a Microscopia Eletrônica de Varredura (MEV) nos esporos.

\begin{tabular}{ccc}
\hline Espécie & Coletor, número, herbário & Local \\
\hline Chryso-hypnum diminutivum & Pôrto, 23753 (UFP) & Brasil \\
Chryso-hypnum elegantulum & Weir, 102 (NY) & Brasil \\
Mittenothamnium reptans & Thiers, 4199 (NY) & Colômbia \\
\hline
\end{tabular}




\title{
CAPÍTULO 3
}

A ser submetido para a revista The Bryologist

\section{Revisão taxonômica de Mittenothamnium Hennings (Hypnaceae) para a região Neotropical.}

\author{
Osvanda Silva de Moura ${ }^{1}$ \& Paulo Eduardo A. S. Câmara ${ }^{1}$ \\ ${ }^{1}$ Universidade de Brasília, Depto de Botânica. Campus Universitário Darcy Ribeiro, \\ Asa Norte, Brasília, DF. Brasília 70910-970. \\ ${ }^{1}$ Autor para correspondência (osvanda@hotmail.com)
}

Resumo - Mittenothamnium é um dos maiores gêneros em número de espécies, da família Hypnaceae, compreendendo cerca de 81 espécies descritas. Apresentam distribuição predominantemente neotropical, com algumas espécies ocorrendo na África. É um gênero considerado notoriamente difícil de ser estudado, com numerosos sinônimos ao seu redor e por apresentar várias espécies com características morfológicas semelhantes. O presente estudo teve como objetivo realizar uma revisão taxonômica de Mittenothamnium para o Neotrópico, esclarecendo assim, a delimitação genérica e consequentemente quantas e quais são às espécies de Mittenothamnium, determinando, portanto, quais os principais caracteres morfológicos informativos para o gênero. Foram reconhecidas nove espécies e confeccionada uma chave de identificação para elas. Além disso, foram feitas uma descrições, notas nomenclaturais, mapas de distribuição, ilustrações e status de conservação para cada uma das espécies. Quando necessário, foram feitas tipificações.

Palavras-chaves: Caulídio Estipitado, Pseudoparáfilo, Papilas, Mittenothamnium, Hypnaceae. 
Abstract - Mittenothamnium is one of the largest genera, in terms of number of species, of the Hypnaceae family. It is comprised of 81 described species. The genus has a predominantly Neotropical distribution, with some species occurring in Africa. The genus is notoriously difficult to be studied, because of the numerous closely related synonyms and due to several species with similar morphological characteristics. The present study aims to perform taxonomic revision of Mittenothamnium of the Neotropics, thus clarifying generic delimitation, and consequently determining the species of Mittenothamnium and which are the main informative morphological characteristics of the genus. Nine species have been included and an identification key for the genus has been made. Descriptions, nomenclature notes, distribution maps, illustrations and the conservation status have been constructed for each species. When necessary, typifications have been made.

Keywords: Stipitate Stem, Pseudoparaphyllia, Papillae, Mittenothamnium, Hypnaceae. 


\section{Introdução}

Hypnaceae é composta por 40 gêneros e 1.000 espécies descritas (Gradstein et al. 2001, Schofield et al. 2014) em quase todo o mundo, sendo mais diversificada nos trópicos, com 21 gêneros e 70 espécies (Schofield et al. 2014). Apresentando ampla diversidade de espécies. É uma família extremamente heterogênea, que em geral pode ser reconhecida por apresentar costa curta e dupla ou ausente, células alares frequentemente diferenciadas e peristômio tipicamente bem desenvolvido com os dentes do exostômio estriados na face frontal (Buck 1998).

Segundo Tsubota et al. (1999), Cox et al. (2010), Huttunen et al. (2012), a família é polifilética, sendo que o tipo Hypnum cupressiforme Hedw. não é proximamente relacionado com a maioria dos gêneros da família, estando agrupado em um clado com apenas um único outro gênero (Eurohypnum leptothallum (Müll. Hal.) Ando).

Entre os diversos gêneros tradicionalmente associados à Hypnaceae, Mittenothamnium Henn., é um dos maiores em número de espécies, compreendendo entre 70-81 espécies descritas (www.tropicos.org). Entretanto, Gradstein et al., (2001) apresentam estimativas mais realistas, e ressaltam que o número de espécies não deve passar de 20 para o gênero, pois do ponto de vista taxonômico é um grupo pouco estudado. Mittenothamnium apresenta distribuição predominantemente neotropical, com algumas espécies ocorrendo na África e em algumas ilhas ao entorno, como em Comoros (Ngazidja). Mittenothamnium é encontrado principalmente nos bosques subandinos até os bosques alto-andinos (submontana a Montana superior), ambientes abertos na margem das florestas, em florestas secundárias, interior de matas ripárias, em sítios sombreados. É pouco encontrada em ambientes úmidos tropicais. Ocorrem como epífitas sobre troncos em decomposição, troncos vivos, ramos, solo e rocha, de 1503400m de altitude (Gradstein et al., 2001). Segundo os autores deste trabalho, esse gênero é considerado notoriamente difícil de ser estudado, com numerosos sinônimos ao seu redor.

\section{Resumo da História Taxonômica de Mittenothamnium:}

Mittenothamnium foi descrito pela primeira vez por Paul Christoph Hennings (1902) na família Hypnaceae, como substituto para Microthamnium, acomodando 20 espécies. 
Posteriormente, Fleischer (1908) apresentou uma monografia transferindo Mittenothamnium para o gênero Stereohypnum. Dois anos depois, Hampe (1910) apresentou Chrysohypnum como nova sinonimização. Mas esse nome (sem o hífen) foi considerado pelo mesmo autor (Hampe) um nome ilegítimo (variação ortográfica), além de não apresentar nenhuma descrição.

E na última tentativa de adequação, Herzog (1916) transferiu Mittenothamnium para Rhizohypnum. Mas esse nome também foi considerado ilegítimo, por não apresentar uma descrição original.

Bartram (1949) expressou a dificuldade em delimitar as espécies de Mittenothamnium (incluindo Chryso-hypnum) e reconheceu que o trabalho feito por Fleischer (1908), em descrever várias espécies de Mittenothamnium (conhecidas anteriormente como Microthamnium), foi uma tarefa demorada e difícil, mas sendo uma referência útil, apresentando informações taxonômicas importantes e baseadas em coleções muito limitadas.

Buck (1984), em sua publicação sobre notas taxonômicas e nomenclaturais, mostrou a dificuldade em aceitar Mittenothamnium como sendo um nome conservado. Nishimura \& Ando (1986) publicaram um trabalho sobre a revisão de algumas espécies de Mittenothamnium para o México concordando com o esclarecimento de Buck (1984). Dez anos mais tarde Nishimura \& Ando (1994), em seus estudos na Flora do México, propuseram oficializar a conservação do nome Mittenothamnium, por ser o nome mais conhecido por muitos taxonomistas (Buck 1998, Buck 2003, Florschütz-de Waard \& Veling 1996, Gradstein et al. 2001, Goffinet \& Shaw 2009, entre outros). Desta maneira, Mittenothamnium passou a ser o nome aceito para o gênero (nomina conservanda) visando a retenção daquele nome que melhor atende à estabilidade da nomenclatura, segundo o Código Internacional de Nomenclatura Botânica (McNeill et al. 2012).

Mittenothamnium apresenta uma longa história de transferência de vários nomes ao seu redor (Churchill \& Linares 1995), sendo considerado um gênero difícil taxonomicamente, apresentando, assim, uma complexa história taxonômica, incluindo alguns gêneros de outras famílias, tornando sua delimitação taxonômica um trabalho difícil (Bartram 1949).

Na classificação mais recente para briófitas, Goffinet \& Shaw (2009), mantiveram Mittenothamnium dentro de Hypnaceae, o que se mantém até os dias atuais. Da mesma 
forma Mittenothamnium, atualmente, é considerado por muitos outros autores, como Buck (1998), Gradstein et al., (2001), Sharp et al., (1994), um nome aceito e sempre esteve associado à Hypnaceae.

Estudos moleculares. Estudos moleculares foram realizados pelos autores deste trabalho (Moura \& Câmara in. prep.) englobando seis espécimes de Mittenothamnium. O gênero se estabeleceu próximo a espécie tipo de Hypnaceae (Hypnum cupressiforme), corroborando com os dados de Huttunen et al. (2012), apresentando um core monofilético, o qual foi reconhecido como gênero. Esse gênero é caracterizado por apresentar caulídio estipitado, com os filídios do estipe diferindo dos filídios do caulídio e da ramificação, células lineares com uma papila no ápice da célula (conhecidas na literatura como células proradas ou prorulosas) e pseudoparáfilo folhoso, geralmente triangular a triangular-lanceolado.

Estudos Taxonômicos de Mittenothamnium- Não há muitos trabalhos taxonômicos publicados específicos sobre Mittenothamnium. Com isso, existem muitos problemas taxonômicos dentro desse gênero. Até o presente, podemos citar Nishimura \& Ando (1986) que realizaram a revisão de seis espécies de Mittenothamnium para o México, onde algumas foram sinonimizadas para Chryso-hypnum. Nishimura \& Kanda (1990) apresentaram uma nova espécie de Mittenothamnium para o sul do Chile (Mittenothamnium deguchii N. Nishim. \& Kanda). Além destes trabalhos, o que existe são publicações gerais sobre o grupo Bryophyta que incluem a família Hypnaceae, e consequentemente o gênero Mittenothamnium, como a Flora das Guianas (Florschützde Waard \& Veling 1996); Gradstein et al. (2001) que apresentou um guia de briófitas para América Tropical; a flora de musgos do México (Sharp et al., 1994); das Índias Ocidentais (Buck 1998), Guiana Francesa Central (Buck 2003), Colômbia (Churchill \& Linares (1995) e Churchill et al., (2009) que publicaram um catálogo das briófitas da Bolívia; Buck (1984 e 1993) que apresentou notas taxonômicas e nomenclaturais de Hypnaceae das Índias Ocidentais e os resultados taxonômicos da expedição do Zaire e Rwanda incluindo sete famílias, entre elas Hypnaceae, respectivamente. Costa et al. (2011) que apresentaram um checklist dos musgos do Brasil, Germishuizen \& Meyer (2003), O' Shea (2006) e Petit (1878) os quais apresentaram Checklists e chaves de identificação incluindo Hypnaceae. 
Portanto, para o Neotrópico, até o presente, ainda não foram feitos estudos taxonômicos e morfológicos específicos para Mittenothamnium. Dessa maneira, configuram-se objetivos deste estudo: 1) Realizar uma revisão taxonômica de Mittenothamnium, para o Neotrópico, 2) Esclarecer, assim, a delimitação genérica e consequentemente quantas e quais são às espécies de Mittenothamnium, determinando quais os principais caracteres morfológicos informativos para o gênero.

\section{Material e Métodos}

Inicialmente foi elaborada uma lista com todas as espécies de Mittenothamnium citadas para região neotropical, através de revisão de literatura e bancos de dados, como sites de pesquisas (www.tropicos.org). Assim, foram resgatados os registros de citações de espécies do gênero Mittenothamnium para neotrópico, e construída uma lista com possíveis sinônimos, locais de coleta, referências bibliográficas e herbários, onde estão depositados estes materiais, além de possíveis instituições fora do país que concentram grande quantidade de material desse gênero.

Em seguida, foram analisadas 796 amostras, contendo Mittenothamnium, presentes nos herbários de ALCB, BM, JE, MG, MO, NY, PC, PRE, R, RB, SP, UB e UFP. Destes, foram examinados 86 tipos de Mittenothamnium, dentre holótipos, isótipos, lectótipo e síntipos. Estes foram localizados por meio de literaturas (Opus princeps) e obtidos através de empréstimos, ou de visitas às instituições onde se encontram.

A identificação das espécies foi baseada na observação de caracteres morfológicos e anatômicos do gametófito e esporófito, com auxílio de estereomicroscópio e microscópio óptico. O material foi analisado sob microscopia de luz e para isso as amostras foram umedecidas em água destilada e montadas em solução de Hoyer (Anderson 1954).

Os termos utilizados nas descrições foram baseados no Glossarium Polyglottum Bryologiae (Magill 1990) e as abreviações dos nomes dos autores foram baseadas em Brummitt \& Powell (1992).

\section{Resultados}




\subsection{Circunscrição do gênero}

O estudo molecular de Moura \& Câmara (in. prep.) sugere que Mittenothamnium possa ter sofrido diversificação recente, assim como Hypnales (Shaw et al. 2003), e que, em razão disso, as espécies de Mittenothamnium sejam muito semelhantes morfologicamente. Estudos morfológicos dos tipos nomenclaturais e das amostras analisadas apontaram que apenas nove das espécies aceitas no começo deste trabalho são reconhecidas para região neotropical: Mittenothamnium andicola (Hook.) Cardot, M. eurystomum (Besch.) Cardot, M. loriforme (Hampe) Cardot, M. plumosum (Herzog) Wijk \& Margad., M. reptans (Hedw.) Cardot, M. salleanum (Besch.) Cardot, M. scalpellifolium (Müll. Hal.) H. A. Crum, M. substriatum (Mitt.) Cardot, e Mittenothamnium spl, que diferem entre si por características do filídio, costa, pseudoparáfilo e esporófito. Características diagnósticas para o gênero são: caulídio estipitado, filídios do caulídio e da ramificação diferenciados pelo tamanho, costa dupla e curta, presença de papilas apenas no ápice da célula e pseudoparáfilo folhoso, triangular a triangular-lanceolado.

Das espécies reportadas para região neotropical, neste estudo até o momento, 32 foram sinonimizados, pelos autores deste trabalho, para Mittenothamnium reptans por apresentarem as características morfológicas observadas para essa espécie, como plantas laxas foliadas com filídios jovens apresentando margens fortemente serruladas no ápice. Seis espécies foram transferidas, pelos autores deste trabalho e Buck (1998), para outros gêneros: Campylium, Isopterygium, Rhacopilopsis, Ectropothecium, Hygrohypnum e Wijkia, por não apresentarem as características citadas para o gênero. E 18 espécies foram sinonimizados para Chryso-hypnum (dentre estes, oito para C. diminutivum e dois para C. elegantulum), e os demais apresentaram nova combinação, citados no subitem 8 (Novas combinações para espécies excluídas de Mittenothamnium).

\subsection{Caracteres morfológicos}

Plantas: Com coloração variada, desde verde oliva até plantas verde-amareladas ou douradas, muitas vezes brilhantes formando tapete solto ou denso (congesto ou laxo). Podem ser rastejantes e pendentes. 
Rizóides: Podem ser marrons a avermelhados, e estão sempre dispostos em feixes no caulídio, variando de simples a ramificados, lisos.

Caulídio primário: Rastejante, radiculoso abaixo, filídios geralmente diferenciados, patente a esquarrosos, ovalados a ovalado-triangular, estipitados, estipe inconspícua a bastante alongada.

Caulídio secundário: Arqueado ou subascendente, ramos irregularmente 1-3 pinado; cilindro central fraco ou ausente; filídios do caulídio e ramos dimórficos.

Pseudoparáfilos: podem ser encontrados nas axilas das ramificações, sendo originados dos primórdios das bases das ramificações (Warnstorf 1904, 1906, Mönkemeyer 1927). Podem ser filamentosos, triangulares a triangular-lanceolados ou folhosos.

Filídios do caulídio: Filídios do caulídio mais ou menos distantes, eretos a patente ou esquarrosos, largamente ovalados a triangular-lanceolados, raramente ovalado-oblongos; ápice acuminado a curto-acuminado ou longo acuminado, côncavo ou plano, plicado ou liso; base curta, decurrente ou não; margem denteada, serrulada ou serrulada acima e inteira abaixo, plana ou recurvada; costa curta e dupla, muitas vezes com uma das forquilhas maior do que a outra, raro ausente; células medianas lineares, papilosas (projetando ângulo distal), raro lisas; células alares diferenciadas, em pequenas quantidades, oblongo-retangulares a subquadráticas, lisas.

Filídios dos ramos: Filídios dos ramos muitas vezes fraco a fortemente complanado, comumente mais curtos, oblongo-lanceolados ou lanceolados, raro ovalados, margens grosseiramente serruladas, costa mais fraca ou ausente; células laminares fortemente papilosas (apenas no ápice da célula).

Células dos filídios: A presença de papilas nos filídios é uma das características que definem o grupo. Através de MEV (microscopia eletrônica de varredura) observouse a presença de papilas no ápice da célula. Papilas são definidas por Magill (1990) como sendo ornamentações celulares vistas ao microscópio como "sólidas protuberâncias".

Sexualidade: Autóicas ou dióicas.

Filídios periqueciais: Ovalados a triangulares, longo-subulados.

Seta: 20-30 mm, delgada, lisa geralmente retorcida, avermelhada a marrom.

Cápsula: horizontal a pendente, avermelhada a marrom, raramente azulada, urna-ovóide a curto-cilíndrica; 2-3 mm geralmente constricta abaixo da boca, célula do 
exotécio quadrada a curto-retangular com a parede levemente ondulada; ânulo diferenciado.

Opérculo: cônico, médio-rostrado ou rostrado.

Peristômio: com dentes do exostômio transversalmente estriados abaixo, papilosos acima; endostômio com uma elevada membrana basal, com cílios em grupo de 1-3, segmentos quilhados e perfurados.

Esporo: Sob microscopia de luz, os esporos são amarelados a esverdeados, esféricos e papilosos. Em microscopia eletrônica de varredura, observam-se esporos pequenos, $10-12 \mu \mathrm{m}$, granulados, apresentando, entretanto, variações no tamanho e na disposição dos grânulos. Isto é, a disposição dos grânulos na superfície da parede se dá de forma esparsa e irregular, onde a exina apresenta-se total ou parcialmente coberta, permitindo, algumas vezes, a visualização da mesma.

\section{Tratamento taxonômico}

MITTENOTHAMNIUM Henn., Hedwigia 41 (Beibl.): 225. 1902; Microthamnium Mitt., J. Linn. Soc. Bot. 12:21, 503. 1869 hom. Illeg., non Nägeli ex Kütz., Sp. Alg. 352. 1849 [Chlorophyta, Chaetophoraceae]; Hypnum sect. Stereo-Hypnum Hampe, Linnaea 31: 529. 1862, nom. nud.; Hypnum sect. Stereohypnum Hampe, Ann. Sci. Nat. Bot. V, 5:317. 1866; Stereohypnum (Hampe) M. Fleisch., Hedwigia 47:273. 1908; Hypnum subgen. Chryso-Hypnum sect. Reptantia Hampe, Flora 50: 76. 1867, nom. nud.; Hypnum sect. Rhizo-Hypnum Hampe, Vidensk. Meddel. Dansk Naturhist. Foren. Kjøbenhavn IV, 1: 143. 1879; Rhizo-hypnum (Hampe) Herzog, Biblioth. Bot. 87: 147. 1916, “Rhizohypnum”. TIPO: Hypnum reptans Hedwig. Sp. Musc. Frond. 265. pl. 68. 1801. Jamaica, Swartz s.n. (Holótipo: G, Isótipo: BM!).

O nome Mittenothamnium é em homenagem a Willian Mitten (1819-1906), considerado por Gradstein et al. (2001), como o autor de um dos trabalhos briológicos mais importante do mundo para as regiões tropicais, Musci austro-americani, publicado em 1869, o qual tratou sobre os musgos da América Latina.

Planta formando tapetes congestos ou laxos, verde-escuros, verde-amareladas a douradas. Caulídio estipitado, livremente a irregularmente ramificado, ramificação 
primária irregularmente ramificada, ascendente, delgada, filídios laxos ou congestos; pseudoparáfilo folhoso e triangular a triangular-lanceolado. Filídios do estipe escassos, diferenciados, patentes a esquarrosos, ovalados a ovalado-triangulares, ápice curtoacuminado; filídios do caulídio e da ramificação diferenciados, filídios do caulídio laxos, patentes a largo-patentes, ovalado-lanceolados a ovalado-triangulares; ápice curto acuminado, côncavo ou plano, levemente plicado ou liso; base levemente decurrente ou não; margens serruladas ou serruladas acima e inteiras abaixo, planas ou recurvadas; costa curta e dupla; células lineares, com papilas apenas na parte superior; células alares diferenciadas, em pequenas quantidades, quadradas a subquadradas; filídios da ramificação oblongo-lanceolados ou lanceolados. Seta amarelada, avermelhada a marrom, 20-30 $\mathrm{mm}$ de comprimento, levemente retorcida. Cápsula horizontal a pendente, ovóide a curto-cilíndrica; célula do exotécio quadrada a curto retangular, com a parede levemente ondulada; ânulo diferenciado. Opérculo cônico-rostrado. Peristômio com exostômio estriado abaixo, papiloso acima; endostômio com cílios em

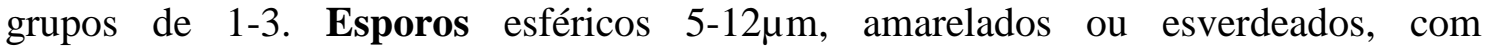
ornamentação granulosa.

Distribuição e Habitat: As espécies de Mittenothamnium são encontradas em altitudes de 0-3400m e em quase todos os continentes: Americano, Africano, Asiático, Europeu e Sul-Americano. Sua maior diversidade em números de espécies ocorre na região neotropical. Crescem como epífitas sobre troncos vivos ou em decomposição, solo e rocha (Gradstein et al., 2001). Formam tapetes e normalmente estão associadas com outros gêneros de musgos como Ectropothecium, Hypnum, Taxithelium, Vesicularia e musgos das famílias Pilotrichaceae, Sematophyllaceae e Thuidiaceae, além de hepáticas como Cheilolejeunea, Plagiochila, Radula entre outras.

Comentários: Mittenothamnium possui várias semelhanças com Chrysohypnum Hampe como filídios do caulídio com região alar desenvolvida ou diferenciada, base não decurrente ou inconspicuamente decurrente; filídios do caulídio lanceolados, ovalado-lanceolados ou ovalados e filídios dos ramos frequentemente complanados (Buck 1998; Sharp et al. 1994). No entanto, diferencia-se de Chryso-hypnum por apresentar caulídio estipitado, pseudoparáfilo folhoso, triangular ou triangularlanceolado e filídios projetando papilas apenas no ápice das células. 
Chave de identificação para as espécies de Mittenothamnium encontradas na região Neotropical.

1. Ramos complanados-foliados; filídios dos ramos estreitamente ovalados a ligulados Mittenothamnium scalpellifolium

1. Ramos julaceos; filídios dos ramos estreitamente lanceolados a ovaladolanceolados. 2

2. Filídios jovens dos ramos com ápice mais serrulado do que os filídios maduros

2. Filídios jovens dos ramos não

diferenciados .4

3. Plantas, $0.45-1.3 \mathrm{~mm}$ de comprimento; laxos foliados. Mittenothamnium reptans 3. Plantas, 1.7-2.15 $\mathrm{mm}$ de comprimento; densamente foliadas Mittenothamnium substriatum

4. Filídios do caulídio orbiculares, células medianas oblongolineares Mittenothamnium salleanum 4. Filídios do caulídio não orbiculares, células medianas longas e lineares. .5

5. Filídios do caulídio e ramos com a margem serrulada do ápice até a base; células do ápice evidentemente papilosas. Mittenothamnium eurystomum 5. Filídios do caulídio e ramos com a margem denteada do ápice até próximo a base, células do ápice pouco papilosas. 6

6. Plantas 1-3 pinadas; filídios do caulídio com ápice longo acuminado Mittenothamnium andicola 6. Plantas 1-2 pinadas; filídios do caulídio com ápice longoloriforme 
7. Filídios do caulídio com a base triangular, reta. Mittenothamnium loriforme 7. Filídios do caulídio com a base cordada. 8

8. Filídios do caulídio triangulares a triangular-ovalados; base cordada e amplamente alargada Mittenothamnium plumosum 8. Filídios do caulídio triangular-orbiculares; base fortemente cordada ou decurrente. Mittenothamnium spl.

4.1. MITTENOTHAMNIUM ANDICOLA (Hook.) Cardot, Revue Bryologique 40: 20. 1913. Hypnum andicola Hooker, Musci Exotici 1: 83. 1818. Hyocomium andicola (Hook.) Spruce, Catalogus Muscorum fere Omnium quos in Terris Amazonicus et Andinis, per Annos 1849--1860, legit Ricardus Spruceus 16. 1867. Leskea andicola (Hook.) Bridel, Bryologia Universa 2: 297. 1827. Microthamnium andicola (Hook.) Mitten, Journal of the Linnean Society, Botany 12: 506. 1869. Rhyzohypnum andicola (Hook.) Herzog, Bibliotheca Botanica 87: 149.1916. Stereohypnum andicola (Hook.) M. Fleischer, Hedwigia 47: 274 280. 5. 1908. TIPO: Equador, Humboldt \& Bonpland 12 (Holótipo: BM!).

Plantas amareladas a marrom. Caulídio estipitado com ramificação 1- 3 pinada. Filídios do estipe menores do que os dos caulídio e ramos, triangular-ovalados; filídios do caulídio ovalado-lanceolados a triangular-ovalados, 1.03-1.09x0.80-0.74 mm; ápice longo acuminado; margens denteadas do ápice até próximo a base; células pouco papilosas na porção superior, alongadas estreitas; células alares em poucas quantidades, quadradas a subquadradas; costa curta e dupla, geralmente do mesmo tamanho; pseudoparáfilo folhoso; filídios da ramificação menores, lanceolados-ovalados 0.72-0.80x1-0.90 mm; ápice longo-acuminado; margem levemente denteada na base e denteada na extremidade superior; costa dupla e desigual; células com papilas na porção superior, alongadas; células alares quadradas a subquadradas. Seta alongada, 
avermelhada a marrom. Cápsula ovalada-lanceolada, cilíndrica avermelhada. Opérculo longo rostrado. Esporo não observado. (Fig.1).
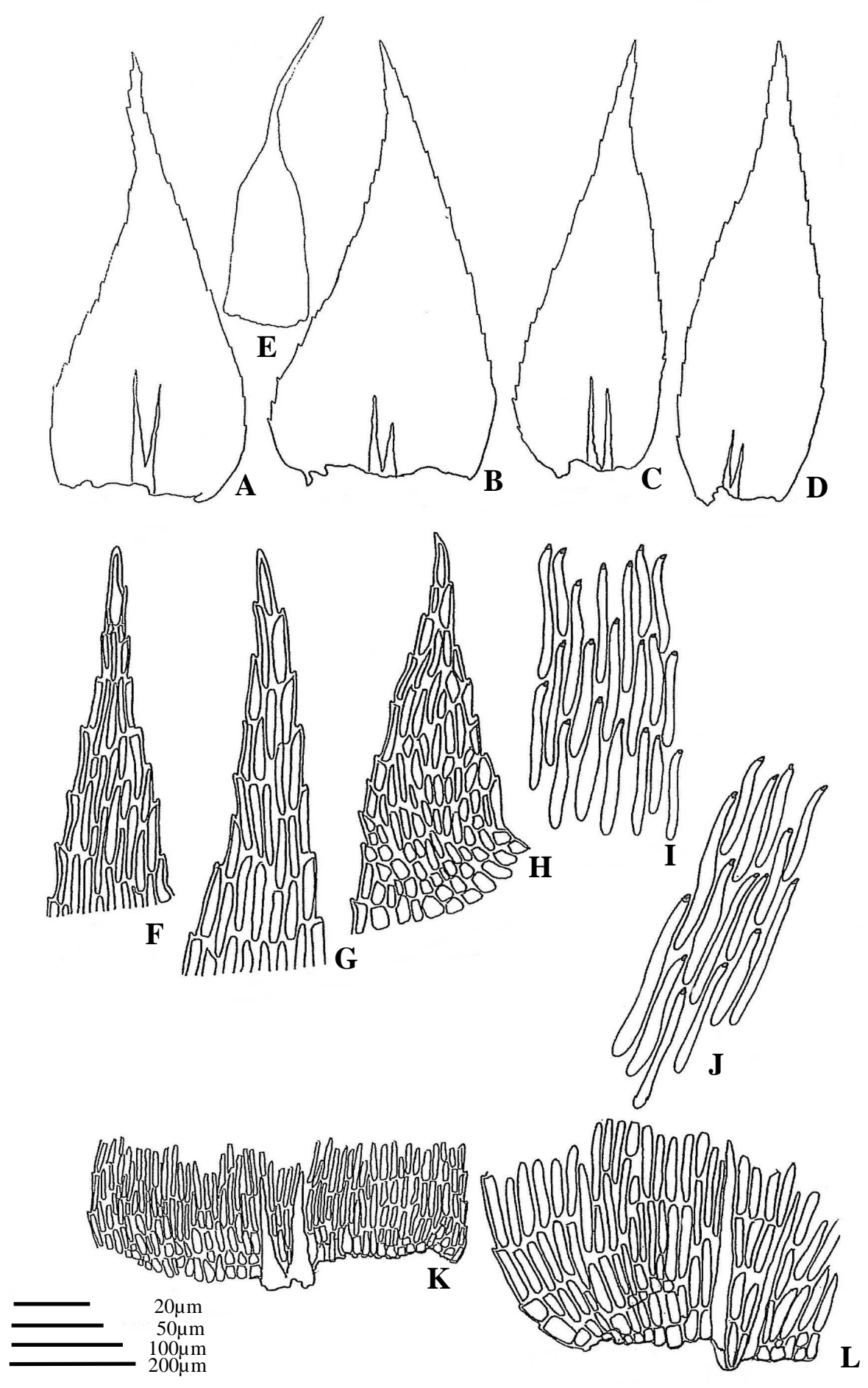

Figura 1. A-L. Mittenothamnium andicola. A- B: Filídios do caulídio. C-D: Filídios da ramificação. E: filídios do periquécio. F-G: Ápice do filídio do caulídio e da ramificação, respectivamente. $\mathrm{H}$ - Pseudoparáfilo triangular-lanceolado. I-J: Células medianas dos filídios do caulídio e ramos, respectivamente. K-L: Base do filídio do 


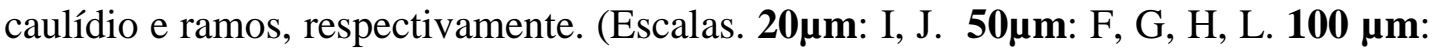
K. $200 \mu \mathrm{m}$ : A, B, C, D. $\mathbf{5 0 0} \boldsymbol{\mu m}$ : E). Prancha: O. S. de Moura.

Comentários: Essa espécie pode ser confundida com Mittenothamnium reptans, mas diferencia-se desta por apresentar filídios do caulídio menores ovalado-lanceolados a lanceolado-agudos, e seta menor com cápsula longa e opérculo rostrado. Foram observadas exsicatas que estavam erroneamente identificadas como Mittenothamnium andicola. Florschütz-de Waard \& Florschütz (1979) e Churchill \& Linares (1995) publicaram uma lista com briófitas reportadas para Colômbia, incluindo M. andicola, mas, esses trabalhos não apresentavam descrição, apenas uma lista com a localização. Contudo, Mitten (1869) apresentou uma breve descrição de $M$. andicola, com as características morfológicas corroborando com este estudo, com sua localização na Colômbia. Assim, os autores deste trabalho apresentarão M. andicola ocorrendo no Equador e Colômbia (Fig. 2).

Distribuição e Habitat: Mittenothamnium andicola pode ser encontrada em floresta tropical, em ambiente úmido. Cresce sobre tronco vivo, a 2000m. Até o momento, essa espécie é localizada apenas no Equador e Colômbia (Fig. 2).

De acordo com os critérios da IUCN, Mittenothamnium andicola apresenta dados insuficientes (categoria DD), por não apresentar informações adequadas para ser avaliada.

Espécimes representativos examinados: EQUADOR Humboldt \& Bonpland 12 (BM). Reconhecida apenas pelo tipo. 


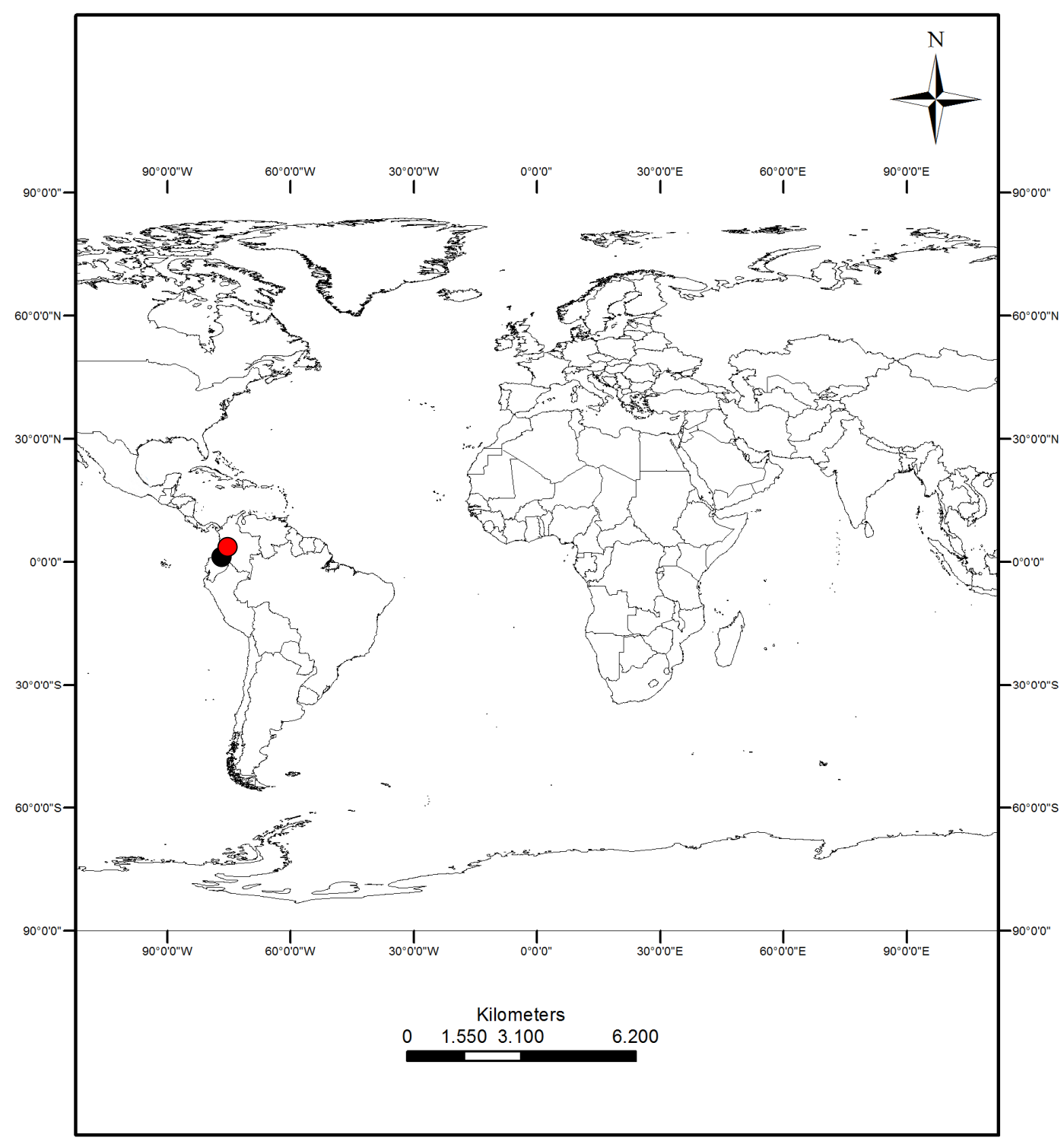

Figura 2. Mapa de distribuição de Mittenothamnium andicola, círculo preto (material observado), círculo vermelho (material não observado).

4.2. MITTENOTHAMNIUM EURYSTOMUM (Besch.) Cardot, Revue Bryologique 40: 21. 1913. Microthamnium eurystomum Besch., Mémoires de la Société des Sciences Naturelles de Cherbourg 21: 269. 1877. TIPO: Paraguai, Villa-Rica, Dans les forêts, Balansa 1199 (Holótipo: BM!; Isótipo: PC!).

Hypnum tamarisciforme Hampe, Videnskabelige Meddelelser fra Dansk Naturhistorisk Forening i Kjøbenhavn ser. 3, 10: 270. 1878. Microthamnium tamarisciforme (Hampe) A. Jaeger, Bericht über die Thätigkeit der St. Gallischen Naturwissenschaftlichen 
Gesellschaft 1877-78: 511. Stereohypnum tamarisciforme (Hampe) M. Fleisch., Hedwigia 47: 274. 1908. Mittenothamnium tamarisciforme (Hampe) Cardot, Revue Bryologique 40: 21. 1913. TIPO: Brasil, Rio de Janeiro, Glaziou 7362 (Lectótipo: PC!; Isolectótipo: PC). Syn. nov.

Stereohypnum rivulare Broth., Revue Bryologique 47: 42. 1920. Microthamnium rivulare (Broth.) Broth., Die natürlichen Pflanzenfamilien, Zweite Auflage 11: 159. 1925. Mittenothamnium rivulare (Broth.) Steere, The Bryologist 51: 159. 1948. TIPO: Equador, Gualaquiza, Allioni 326 (Lectótipo PC! Designado aqui). Syn. nov.

Plantas verde-amareladas a douradas. Caulídio estipitado com ramificação 1-3 pinada. Filídio do caulídio ovalado-lanceolado, 0.69-0.86x0.34-0.38 mm; ápice curto acuminado ou longo-acuminado com células evidentemente papilosas, margens serruladas do ápice até a base; células lineares fortemente papilosas; células alares levemente diferenciadas, retangulares a sub-retangulares, 1-3 fileiras; base do filídio geralmente reta; costa dupla e curta, geralmente do mesmo tamanho, pseudoparafilo triangular a triangular-lanceolado; filídios dos ramos ovalados a ovalados-lanceolados 0.27-0.59x0.10-0.26 mm, ápice curto-acuminado, margem fortemente serrulada da metade do filídio até o ápice; base do filídio levemente cordada; costa dupla e curta; células medianas com papilas bem evidentes; células alares levemente diferenciadas, retangulares a subretangulares. Seta com cerca de $3 \mathrm{~cm}$, alongada, avermelhada. Cápsula cilíndrica avermelhada. Opérculo cônico rostrado. Esporo não observado. (Fig. 3). 

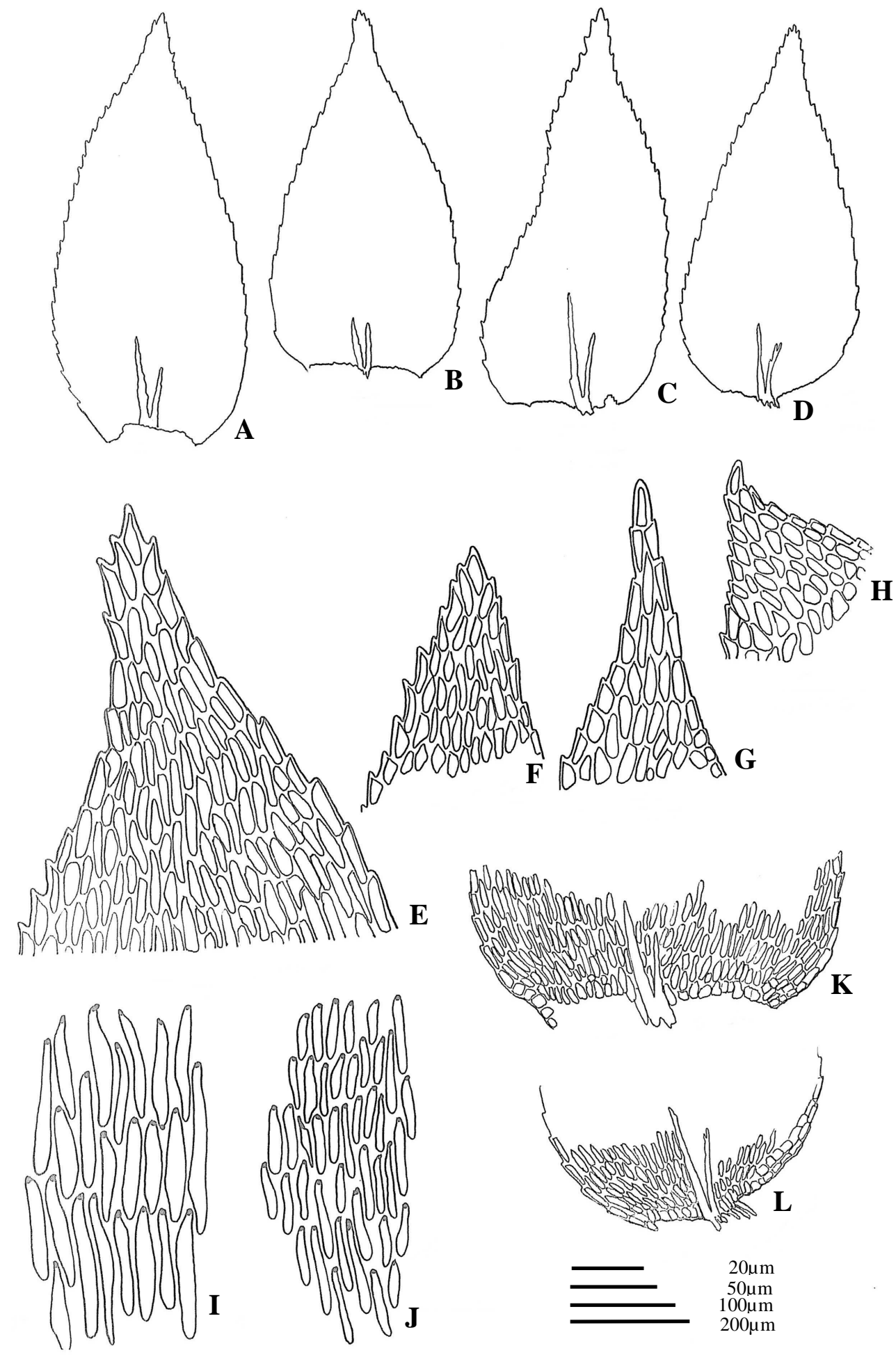

Figura 3. A-L. Mittenothamnium eurystomum. A-B: Filídios do caulídio. C-D: Filídios da ramificação. E-F: Ápice do filídio do caulídio e ramos, respectivamente. G-H: Pseudoparáfilos. I-J: Células medianas do filídio do caulídio e ramos, respectivamente. K-L:

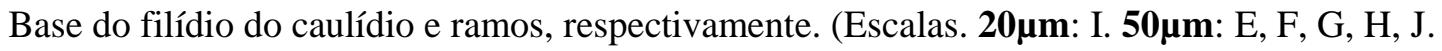
$100 \mu \mathrm{m}$ : K, L. $200 \mu \mathrm{m}$ : A, B, C, D). Prancha: O. S. de Moura. 
Comentários: Mittenothamnium eurystomum mostrou-se ser comum em algumas regiões neotropicais. Essa espécie se distingue das demais espécies do gênero Mittenothamnium por apresentar filídios largamente ovalados-lanceolados com a margem fortemente serrulada. Era considerada endêmica do Paraguai, no entanto, ao sinonimizá-la com $M$. rivulare e $M$. tamarisciforme, ela passou a ser reportada também para o Brasil e Equador.

Distribuição e Habitat: Essa espécie ocorre em ambientes abertos, úmidos, próximos a córregos, em tronco vivo e rochas. Na região neotropical ocorrem no Paraguai, Brasil e Equador. (Fig.4).

De acordo com os critérios da IUCN a espécie $M$. eurystomum não está ameaçada e apresenta status pouco preocupante (categoria LC).

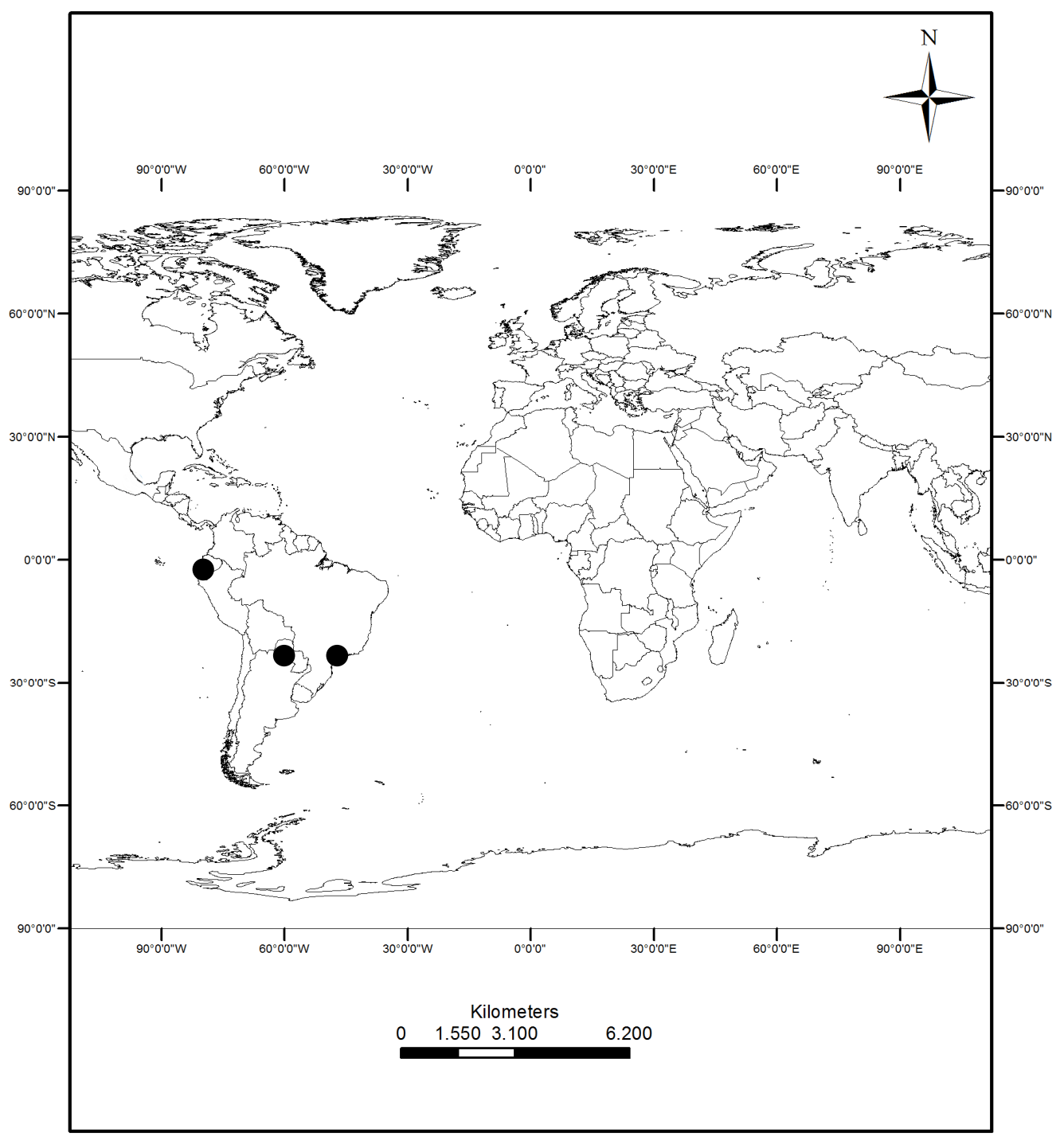

Figura 4. Mapa de distribuição de Mittenothamnium eurystomum. 
Espécimes representativos examinados: BRASIL, Rio de Janeiro, Glaziou 7362 (BM). EQUADOR, Gualaquiza, Allioni 326 (PC). PARAGUAI (reconhecida pelo tipo).

4.3. MITTENOTHAMNIUM LORIFORME (Hampe) Cardot, Revue Bryologique 40: 21. 1913. Hypnum loriforme Hampe, Linnaea 32: 160. 1863. Microthamnium loriforme (Hampe) Mitt., Journal of the Linnean Society, Botany 12: 508. 1869. Rhytiadelphus novogranatensis R. S. Willians, The Bryologist 33: 75. 14. 1930. TIPO: Colômbia, Nova Granata, Lindig 2064 (Holótipo: BM!; Isótipo: BM!, PC).

Plantas verde amareladas a castanho-douradas, formando tapetes. Caulídio estipitados com ramificação 1-2 pinado, ereta; corte transversal com 3-5 fileiras de pequenas células. Filídios do estipe com margens levemente serruladas; filídios do caulídio maiores, 2.19-2.236x0.60-0.66 mm, triangular-ovalados; com ápice longoloriforme e estreitamente acuminado serrulado; margens levemente serruladas da metade do filídio até o ápice; células alares diferenciadas, quadradas a retangulares 3-6 fileiras; células lineares com papila na porção superior; costa curta e dupla, às vezes até a metade do filídio; base retangular, reta, levemente cordada; pseudoparafilo folhoso, triangular com ápice longo-acuminado. Filídios dos ramos algumas vezes maiores, 1.552.25x0.81-0.98 mm, lanceolados a triangular-lanceolados, margens serruladas, especialmente no ápice; ápice longo-loriforme a estreitamente acuminado; costa curta e dupla, onde uma das bifurcações pode ser maior que a outra; células medianas lineares, com papila apenas na porção superior; células alares pouco diferenciadas, retangularesalongadas, 1-4 fileiras. Seta ereta, alongada, 2-4 cm de comprimento, delgada, avermelhada a marrom. Cápsula horizontal a pendula, oblongo-elíptica. Opérculo cônico acuminado. Esporo não observado. (Fig. 5) 


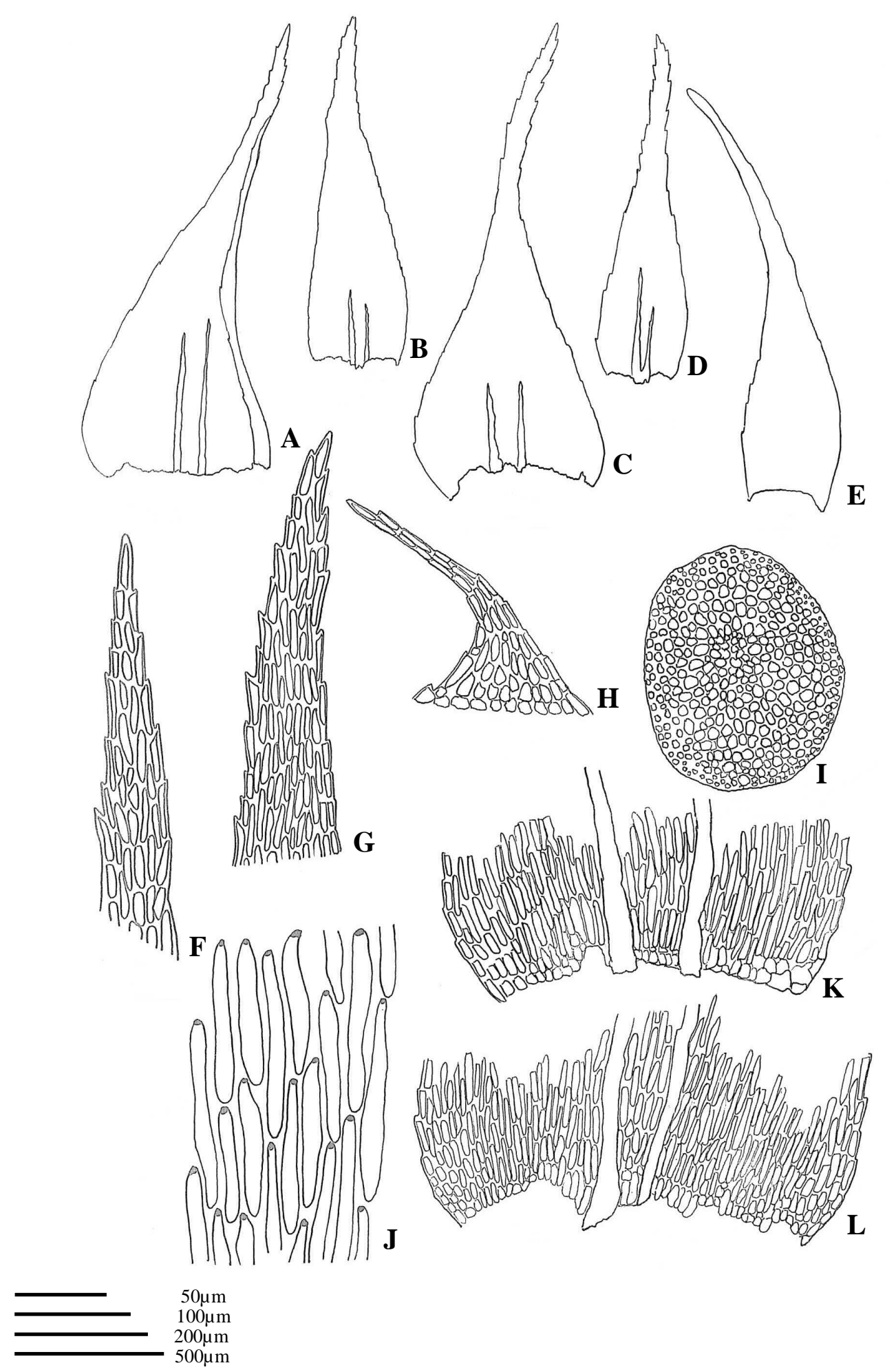

Figura 5. A-L. Mittenothamnium loriforme. A-B: Filídios do caulídio. C-D: Filídios da ramificação. E: Filídio do periquécio. F-G: Ápice do filídio do caulídio e ramos, respectivamente. H: Pseudoparáfilo. I: Corte transversal. J: Células medianas do filídio da ramificação. K-L: Base do filídio do caulídio e ramos, respectivamente.

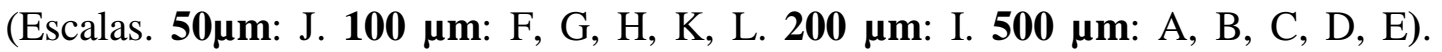
Prancha: O. S. de Moura. 
Comentários: Mittenothamnium loriforme é considerada bem distinta, apresentando pouca semelhança morfológica com as demais espécies de Mittenothamnium, facilmente reconhecida por apresentarem plantas com caulídio rígido, filídios ovalado-triangular, 2.19-2.236x0.60-0.66 $\mathrm{mm}$; filídios com ápice estreitamente longo-loriforme, serrulados; pseudoparáfilo com ápice extremamente alongado. Além disso, estudos moleculares (Moura \& Câmara, in. prep.) confirmaram o posicionamento desta como pertencente ao gênero Mittenothamnium.

Distribuição e Habitat: Essa espécie é encontrada em florestas úmidas, em lugares sombreados ou parcialmente sombreados, em tronco vivo e no solo. A altitude pode variar de 2500-2700m. Pode ser encontrado na Colômbia, com registros em Antioquia, Cundinamarca, Bogotá (Churchill \& Linares 19995) e no Peru (Fig.6).

De acordo com os critérios da IUCN, essa espécie não está ameaçada e apresenta status pouco preocupante (categoria LC). 


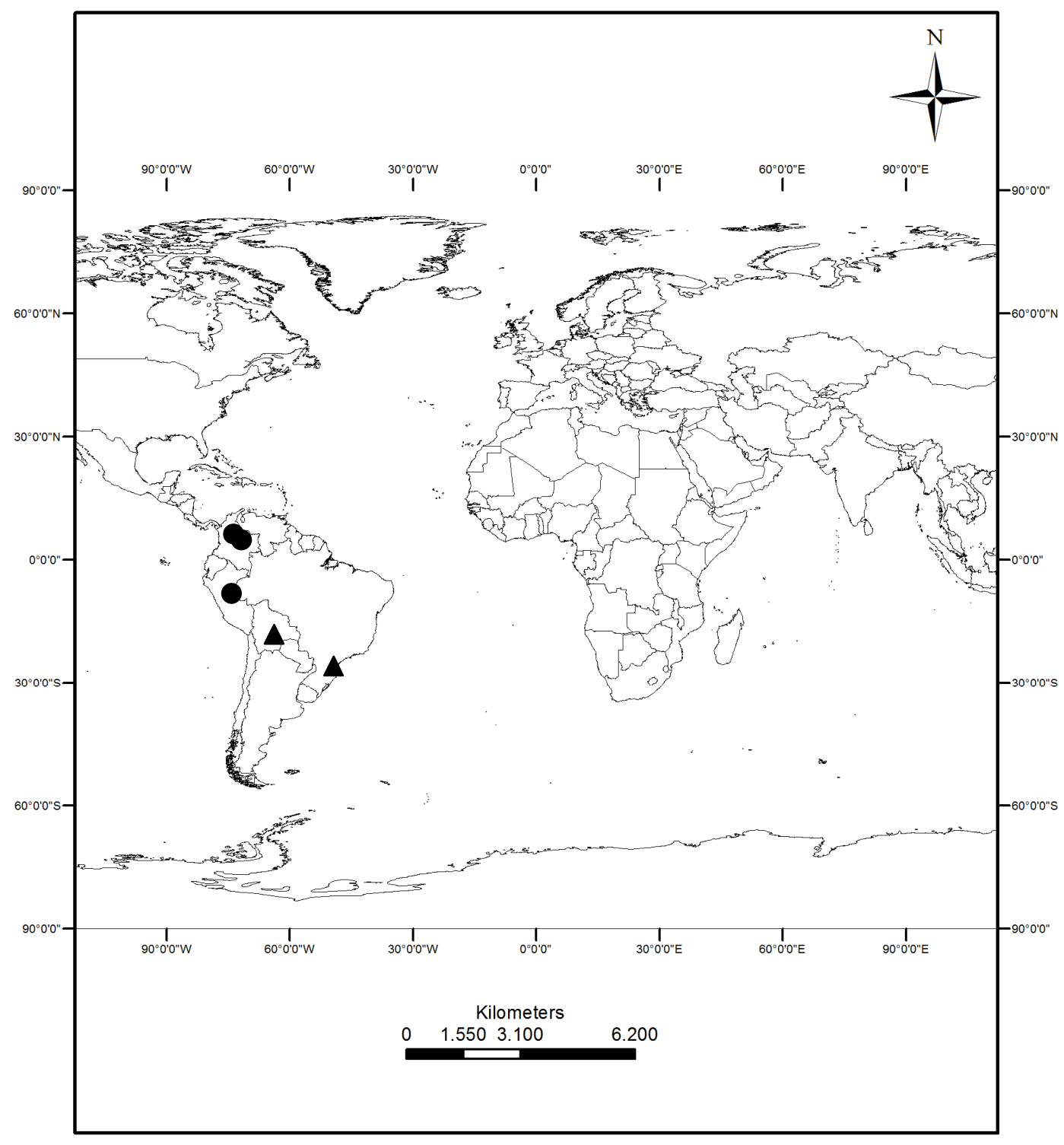

Figura 6. Mapa de distribuição de Mittenothamnium loriforme (círculo), Mittenothamnium plumosum (triângulo).

Espécimes representativos examinados: COLÔMBIA, Andes Bogotensis, Weir 190 (BM); Antioquia, MacDougal et al. 4237 (NY, MO). PERU, Pasco, Opisso \& Lingán 1826 (MO).

4.4. MitTENOThamNiUM PLUMOSUM (Herzog) Wijk \& Margad., Taxon 11: 222. 1962. Hypnum plumosum Herzog, Beihefte zum Botanischen Centralblatt. Zweite Abteilung, Systematik, Pflanzengeographie, angewandte Botanik 26(2): 85. 1909. 
Rhizohypnum plumosum (Herzog) Herzog, Bibliotheca Botanica 87: 149. 1916. Microthamnium plumosum (Herzog) Brotherus, Die natürlichen Pflanzenfamilien, Zweite Auflage 11: 472. 1925. TIPO: Bolívia, Cochabamba, Herzog 79 (Holótipo: JE, Isótipo: PC!).

Plantas verde amareladas a douradas, formando tapetes. Caulídio estipitados com ramificação 1-2 pinado. Filídios do estipe com margens levemente serruladas; filídios do caulídio maiores, $0.62-0.66 \times 0.47-0.55 \mathrm{~mm}$, triangular a triangular-ovalados, com ápice curto curto-acuminado; margens levemente serruladas do ápice até próximo a base; células alares diferenciadas, quadradas a subquadradas 4-6 fileiras; células lineares com papila na porção superior; costa até metade do filídio e dupla; base cordada e alargada; pseudoparáfilo triangular. Filídios dos ramos com 1.05-0.92x0.39$0.38 \mathrm{~mm}$, lanceolado-ovalados, margens fortemente serruladas, especialmente no ápice, e levemente serrulada na base; ápice curto acuminado; costa dupla até metade do filídio; células medianas lineares, com papila apenas na porção superior; células alares pouco diferenciadas, quadradas a subquadradas, 2-4 fileiras. Seta ereta, alongada, 3-3.5 cm de comprimento, avermelhada. Cápsula horizontal. Opérculo não observado. Esporo não observado. (Fig. 7). 

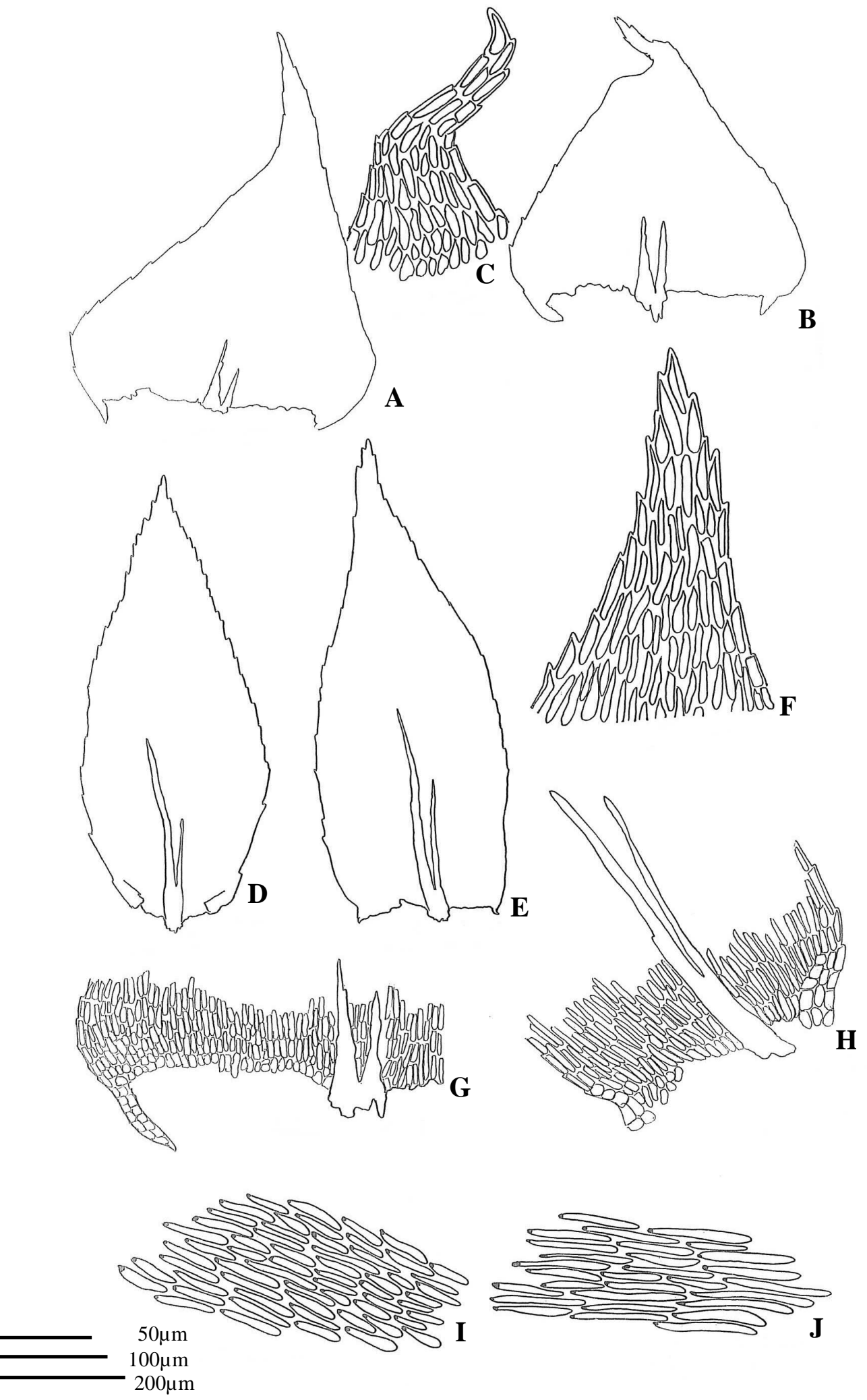

Figura 7. A-J. Mittenothamnium plumosum. A-B: Filídios do caulídio. C: Ápice do filídio do caulídio. D-E: Filídios da ramificação. F: Ápice do filídio da ramificação. G-H: Base do filídio do caulídio e ramos, respectivamente. I-J: Células medianas do

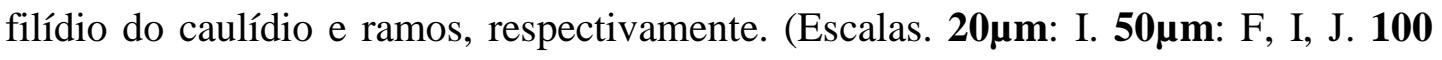
$\mu \mathrm{m}:$ G, H. $200 \mu \mathrm{m}$ : A, B, C, D, D, E). Prancha: O. S. de Moura. 
Comentários: Mittenothamnium plumosum é facilmente reconhecida por apresentar filídios do caulídio triangular a triangular-ovalados, base levemente cordada a amplamente alargada. Essa espécie tinha sido reportada apenas para Bolívia, através do material tipo. No entanto, uma amostra também identificada como M. andicola, do Brasil, foi analisada e verificou-se que na verdade trata-se de $M$. plumosum. Dessa maneira, $M$. plumosum também passa a ser reportada para o Brasil (nova ocorrência para o país).

Distribuição e Habitat: Essa espécie é encontrada em floresta úmida, em lugares sombreados ou parcialmente sombreados, em tronco vivo e no solo. A altitude pode variar até $2.200 \mathrm{~m}$. Ocorre na Bolívia e Brasil (Fig. 6).

De acordo com os critérios da IUCN, essa espécie não está ameaçada e apresenta status pouco preocupante (categoria LC).

Espécimes representativos examinados: BRASIL, Santa Catarina, Vital \& Buck 12410 (NY). BOLÍVIA (reconhecida pelo tipo).

4.5. MitTENOTHAMNIUM REPTANS (Hedw.) Cardot, Revue Bryologique 40: 21. 1913. Hypnum reptans Hedwig, Species Muscorum Frondosorum 265. pl.68. 1801. Stereodon reptans (Hedw.) Mitten, Journal of the Proceedings of the Linnean Society, Botany 7: 158. 1863. Hyocomium reptans (Hedw.) Spruce, Catalogus Muscorum fere Omnium quos in Terris Amazonicus et Andinis, per Annos 1849--1860, legit Ricardus Spruceus 16. 1867. Microthamnium reptans (Hedw.) Mitten, Journal of the Linnean Society, Botany 12: 506. 1869. Stereohypnum reptans (Hedw.) M. Fleischer, Hedwigia 47: 275. 1. 1908. Rhizohypnum reptans (Hedw.) Herzog, Bibliotheca Botanica 87: 149. 1916. TIPO: Jamaica, Swartz s. n. (Holótipo: G, Isótipo: BM!).

OBS: Notas nomenclaturais (a seguir) apenas para os tipos não vistos e para os síntipos que não foram lectotipificados: 
Microthamnium reptans var. squarrosulum Besch. ex Paris, Index Bryologicus 811. 1897, nom. Illeg. orthogr.. Microthamnium reptans var. squarrosulum Bescherelle, Annales des Sciences Naturelles; Botanique, sér. 6, 3: 262. 1876. Stereohypnum reptans var. squarrosulum (Besch.) M. Fleiscer, Hedwigia 47: 277. 1908. TIPO: Guadeloupe, L'Herminier s. $n$. (Holótipo: NY).

Notas nomenclaturais: Esse material tipo não foi observado pelos autores. Porém, Fleischer (1908) apresenta como sinônimo desta espécie Microthamnium minusculifolium Müll. Hal., e o material tipo deste foi analisado pelos autores, onde os mesmos confirmaram ser Mittenothamnium reptans.

Microthamnium atro-viride Bescherelle, Bulletin de l'Herbier Boissier 2: 399. 1894. Mittenothamnium atroviride (Besch.) Cardot, Revue Bryologique 40: 20. 1913. TIPO: Costa Rica, Lehmann 1128 (Holótipo: BM, Isótipo: PC!). Syn. nov.

Microthamnium bescherellei Renauld. \& Cardot, Bulletin de la Société Royale de Botanique de Belgique 33(2): 132. 1895. Mittenothamnium bescherellei (Renauld \& Card.) Cardot, Revue Bryologique 40: 20. 1913. TIPO: La Reunión, Rivière du Mât, Rodriguez s.n. (Holótipo: PC!). Syn. nov.

Microthamnium brachythecioides Renauld \& Cardot, Bulletin de la Société Royale de Botanique de Belgique 34(2): 77. 1896. Mittenothamnium brachythecioides (Renauld \& Card.) Cardot, Revue Bryologique 40: 20. 1913. TIPO: Índia, Sikkim, Darjeeling, Stevens 83 (Holótipo: PC!). Syn. nov.

Microthamnium ctenidioides Dixon, Transactions of the Royal Society of South Africa 8: 217. pl. 12: 18. 1920. Mittenothamnium ctenidioides (Dixon) Schelpe, Memoirs of the Botanical Survey of South Africa 43: 7. 1979. TIPO: África, Hogsback, Henderson 220 (Holótipo: BM!). Syn. nov.

Microthamnium cygnicollum Dixon, Journal of Botany, British and Foreign 53: 21. 1915. Mittenothamnium cygnicollum (Dixon) Wijk \& Margad., Taxon 14: 197. 1965. TIPO: África, Kooksbosch, Breutel s.n. (Holótipo: BM!). Syn. nov. 
Stereohypnum decurrens Herzog, Beihefte zum Botanischen Centralblatt. Zweite Abteilung, Systematik, Pflanzengeographie, angewandte Botanik 26(2): 84. 1909. Mittenothamnium decurrens (Herzog) Wijk \& Margad., Taxon 10: 25. 1961. TIPO: Bolívia, Cochabamba, Herzog s. n. (Holótipo: JE, Isótipo: P!). Syn. nov.

Hypnum heterostachys Hampe, Videnskabelige Meddelelser fra Dansk Naturhistorisk Forening i Kjøbenhavn ser. 3, 6: 169. 1874. Microthamnium heterostachys (Hampe) A. Jaeger, Bericht über die Thätigkeit der St. Gallischen Naturwissenschaftlichen Gesellschaft 1876-77: 431. 1878. Stereohypnum heterostachys (Hampe) M. Fleischer, Hedwigia 47: 274. 1908. Mittenothamnium heterostachys (Hampe) Cardot, Revue Bryologique 40: 21. 1913. Rhizohypnum heterostachys (Hampe) Herzog, Bibliotheca Botanica 87: 149. 1916. TIPO: Brasil, Rio de Janeiro [Corcovado, 14 Aug. 1873], Glaziou 7150 (Lectótipo: PC!, Isolectótipo: PC!). Syn. nov.

Hypnum langsdorffi Hooker, Synopsis Plantarum 1: 62. 1822. Hyocomium langsdorffi (Hook.) Spruce, Catalogus Muscorum fere Omnium quos in Terris Amazonicus et Andinis, per Annos 1849--1860, legit Ricardus Spruceus 16. 1867. Microthamnium langsdorffi (Hook.) Mitten, Journal of the Linnean Society, Botany 12: 507. 1869. Stereohypnum langsdorffi (Hook.) M. Fleischer, Hedwigia 47: 274, 284. 7 a-e. 1908. Mittenothamnium langsdorffi (Hook.) Cardot, Revue Bryologique 40: 21. 1913. Rhizohypnum langsdorffi (Hook.) Herzog, Bibliotheca Botanica 87: 172, 288. 1916. TIPO: Brasil, Langsdorf s.n. (Holótipo: BM!). Syn. nov.

Microthamnium laxulum E. B. Bartram, Contributions from the United States National Herbarium 26: 113. f. 39: f-j. 1928. Mittenothamnium laxulum (E. B. Bartram) F. D. Bowers, Journal of the Hattori Botanical Laboratory 33: 25. 1970. TIPO: Costa Rica, Guanacaste, Standley \& Valerio 46539 (Holótipo: FH, Isótipo: NY!). Syn. nov.

Mittenothamnium lehmannii (Besch.) Cardot, Revue Bryologique 40: 21. 1913. Microthamnium lehmannii Besch. Bulletin de l'Herbier Boissier 2: 398. 1894. TIPO: Costa Rica, Bei Tobosi, Lehmann 1142 (Holótipo: BM!, Isótipo: PC!). Syn. nov. 
Microthamnium leptoreptans Brotherus, Boletim da Sociedade Broteriana 8: 185. 1890. Mittenothamnium leptoreptans (Broth.) Cardot, Revue Bryologique 40: 21. 1913. TIPO: São Tomé e Príncipe, Quintas 1422 (Holótipo: H, Isótipo: NY!). Syn. nov.

Microthamnium longo-reptans Müll. Hal., Hedwigia 36: 136. 1897. Mittenothamnium longoreptans (Müll. Hal.) Cardot, Revue Bryologique 40: 21. 1913. TIPO: Argentina, Siambón, Lorentz s. n. (Holótipo: B, provavelmente destruído, Isótipo: NY!). Syn. nov.

Microthamnium macroblepharum Besch., Annales des Sciences Naturelles; Botanique, sér. 7, 20: 51. 1894. Mittenothamnium macroblepharum (Besch.) Cardot, Revue Bryologique 40: 21. 1913. TIPO: Polinésia Francesa, Nuhiva - Archipel des Marquises, Hombron 02, Jardim 10 (Síntipo: PC!). Syn. nov.

Notas nomenclaturais: $\mathrm{Na}$ obra original dessa espécie aparecem dois números de coletas por dois coletores diferentes (Hombron $n^{o} 2$, e Jardin $n^{o} 10$ ). Porém, os autores deste artigo encontraram apenas uma das amostras, localizada no herbário PC (PC0695324!). Dessa maneira, não foi possível lectotipificar esse nome.

Hypnum macrodontium Hornsch., Flora Brasiliensis 1(2): 82. 1840 Microthamnium macrodontium (Hornsch.) Mitten, Journal of the Linnean Society, Botany 12: 507. 1869. Stereohypnum macrodontium (Hornsch.) M. Fleischer, Hedwigia 47: 274. 293. 12. 1908. Mittenothamnium macrodontium (Hornsch.) Cardot, Revue Bryologique 40: 21. 1913. TIPO: Brasil, Vila Rica, Moritz 65b (Lectótipo: BM!, Designado aqui, Isolectótipo: BM!). Syn. nov.

Microthamnium madagassum Besch., Annales des Sciences Naturelles; Botanique, sér. 6, 10: 312. 1880. Mittenothamnium madagassum (Besch.) Cardot, Revue Bryologique 40: 21. 1913. TIPO: Madagascar, Pervillé 825 (Holótipo: BM!). Syn. nov.

Mittenothamnium megapelmatum (Müll. Hal.) Cardot, Revue Bryologique 40: 21. 1913. Microthamnium megapalmatum Müll. Hal., Bulletin de l'Herbier Boissier 5: 215. 1897. TIPO: Guatemala, Museo Zoologico Florentino, Müller 678 (Lectótipo: PC!, Designado aqui, Isolectótipo: PC!, NY!). Syn. nov. 
Hypnum microthamnioides Müll. Hal., Abhandlungen herausgegeben vom Naturwissenschaftlichen Vereins zu Bremen 7: 212. 1881. Mittenothamnium microthamnioides (Müll. Hal.) Wijk \& Margad, Taxon 9: 51. 1960. Trichosteleum microthamnioides (Müll. Hal.) C. H. Wright, Journal of Botany, British and Foreign 26: 267. 1888. Rhizohypnum microthamnioides (Müll. Hal.) M. Fleischer, Die Musci der Flora von Buitenzorg 4: 1378, 1719. 1923. TIPO: Brasil, Santa Catarina, Pedras Grandes, Ule 189 (Holótipo: B, provavelmente destruído, Isótipo: BM!). Syn. nov.

Mittenothamnium minusculifolium (Müll. Hal.) Cardot, Revue Bryologique 40: 21. 1913. Microthamnium minusculifolium Müll. Hal., Bulletin de l'Herbier Boissier 5(7): 565. 1897. TIPO: Jamaica, Newhaven Pass, Vinegar Hill, Harris 11014, 11018, 11031, 11036 (Síntipo: NY!). Syn. nov.

Notas nomenclaturais: A maioria dos tipos de Müller foram destruídos em Berlin (Sayre 1977). Mas muitas duplicatas foram enviadas para outros herbários, como BM, NY, MICH, F. Dentre estas estão 13 espécimes tipo de Mittenothamnium minusculifolium. Destes, apenas quatro, localizados no herbário de NY foram possíveis de serem analisados (NY01524058!, NY01524059!, NY1717305!, NY1717307!), pois os demais encontram-se nos seguintes herbários: BM (BM000862433, BM000862379, BM000862434, BM000862435), MICH (MICH526779), F (F001310C). Dessa maneira, os autores deste artigo, optaram em não lectotipificar esse nome, por não terem conseguido analisar todas as amostras disponíveis.

Mittenothamnium modestum (Herzog) Wijk \& Margad, Taxon 11: 222. 1962. Stereohypnum modestum Herzog, Beihefte zum Botanischen Centralblatt. Zweite Abteilung, Systematik, Pflanzengeographie, angewandte Botanik 26(2): 84. 1909. Rhizohypnum modestum (Herzog) Herzog, Bibliotheca Botanica 87: 172. 1916. TIPO: Bolívia, Cerro Amboró, Herzog s.n. (Holótipo: JE, Isótipo: PC!). Syn. nov.

Mittenothamnium mucidum (Renauld \& Card.) Cardot, Histoire Physique, Naturelle et Politique de Madagascar, Mousses 445. 1915. Microthamnium mucidum, Bulletin de la 
Société Royale de Botanique de Belgique 33(2): 133. 1895. TIPO: Nova Caledônia, Mont Atso, Savez 31 (Lectótipo: PC!, Designado aqui, Isolectótipo: PC!). Syn. nov.

Mittenothamnium nanopolymorphum (Müll. Hal.) Cardot, Revue Bryologique 40: 21. 1913. Hypnum nano-polymorphum Müll. Hal., Linnaea 42: 498. 1879. Microthamnium nanopolymorphum (Müll. Hal.) Brotherus, Die Natürlichen Pflanzenfamilien I (3): 1049. 1908. TIPO: Venezuela, Colônia Tovar, Fendler 151 (Holótipo: B, possivelmente destruído, Isótipo: BM!). Syn. nov.

Microthamnium oxystegum Spruce ex Mitten, Journal of the Linnean Society, Botany 12: 505. 1869. Stereohypnum oxystegum (Spruce ex Mitt.) M. Fleischer, Hedwigia 47: 274. 1908. Mittenothamnium oxystegum (Spruce ex Mitt.) Cardot, Revue Bryologique 40: 21. 1913. Rhizohypnum oxystegum (Spruce ex Mitt.) Herzog, Bibliotheca Botanica 87: 148. 1916. TIPO: Peru, Tarapoto, Spruce 1082, 1083,1085, 1091, 1092 (Síntipo: NY!, BM!). Syn. nov.

Notas nomenclaturais: A maioria dos tipos de Spruce encontra-se nos herbários de K e MANCH. Mas, nenhuma amostra tipo de Microthamnium oxystegum, foi referida online para estes herbários. As 15 amostras do material tipo (Síntipos) dessa espécie encontram-se referidas apenas para NY, BM, PC e E. Dessas 15, apenas oito foram possíveis de analisar: NY (NY01238986! NY01238988!), BM (BM000723296!, BM000723295!, BM000723303!, BM000723306!, BM000723302!, BM000723304!), pois foram os únicos disponibilizados por esses herbários. As demais exsicatas (NY01238987, BM000723305, BM000723297, PC0695297E00011720, E00011719, E000117221) não foram disponibilizadas para análise. Dessa maneira, os autores deste artigo, escolheram em não lectotipificar esse nome.

Mittenothamnium pringlei Cardot, Revue Bryologique 37: 54. 1910. Microthamnium pringlei (Card.) Brotherus, Die natürlichen Pflanzenfamilien, Zweite Auflage 11: 472. 1925. TIPO: México, Oaxaca, Sierra de San Felipe, Pringle $3 a$ (Holótipo: PC, Isótipo: NY!). Syn. nov. 
Hypnum pseudoreptans Müll. Hal., Botanische Zeitung (Berlin) 14: 439. 1856. Stereodon pseudoreptans (Müll. Hal.) Mitten, Journal of the Proceedings of the Linnean Society, Botany 7: 159. 1864. Microthamnium pseudoreptans (Müll. Hal.) A. Jaeger, Bericht über die Thätigkeit der St. Gallischen Naturwissenschaftlichen Gesellschaft 1876-77: 428 (Gen. Sp. Musc. 2: 494). 1878. Stereohypnum reptans var. pseudoreptans (Müll. Hal.) M. Fleischer, Hedwigia 47: 278. 3. 1908. Stereohypnum pseudoreptans (Müll. Hal.) Brotherus, Denkschriften der Kaiserlichen Akademie der Wissenschaften, Wien. Mathematisch-naturwissenschaftliche Klasse 88: 742. 1913. Mittenothamnium pseudoreptans (Müll. Hal.) Cardot, Revue Bryologique 40: 21. 1913. Microthamnium reptans var. pseudoreptans (Müll. Hal.) Dixon, Die natürlichen Pflanzenfamilien, Zweite Auflage 11: 472. 1925. Mittenothamnium reptans var. pseudoreptans (Müll. Hal.) Dixon, Scientific Survey of Porto Rico and the Virgin Islands 7: 583. 1957. TIPO: África do Sul, Swellendam, Mundt s.n. (Holótipo: B, provavelmente destruído, Isótipo: BM!). Syn. nov.

Mittenothamnium rostratum (Renauld \& Card.) Cardot, Revue Bryologique 40: 21. 1913. Microthamnium rostratum Renauld \& Cardot, Bulletin de la Société Royale de Botanique de Belgique 41(1): 138. 1905. TIPO: Costa Rica, Fôret de Juan Viñas, Pittier 5785 (Holótipo: PC!). Syn. nov.

Mittenothamnium russellii R. S. Willians, Journal of the Washington Academy of Sciences 20(19): 472. 1-13. 1930. TIPO: Brasil, São Paulo, Rose \& Russel 20469 (Holótipo: NY!). Syn. nov.

Mittenothamnium sordidum (Renauld \& Card.) Cardot, Revue Bryologique 40: 21. 1913. Microthamnium sordidum Renauld \& Cardot, Bulletin de la Société Royale de Botanique de Belgique 41(1): 138. 1905. Stereohypnum sordidum (Renauld \& Card.) M. Fleischer, Hedwigia 47: 274. 1908. TIPO: Costa Rica, La Palma, Pittier 5711 (Holótipo: PC, Isótipo: NY!). Syn. nov.

Mittenothamnium tamariscifrons (Broth. \& Geh.) Cardot, Revue Bryologique 40: 21. 1913. Microthamnium tamariscifrons Brotherus \& Geheeb, Revue Bryologique 27: 66. 
1900. TIPO: Brasil, Puiggari 993 (Lectótipo: BM!, Designado aqui, Isolectótipo: JE). Syn. nov.

Microthamnium tuerckheimii Müll. Hal., Bulletin de l'Herbier Boissier 5: 215. 1897. TIPO: Guatemala, Vera Paz, Türckheim s. $n$. (Holótipo: B, provavelmente perdido em 1943, Isótipo: NY!). Syn. nov.

Microthamnium versipoma Hamp., Bericht über die Thätigkeit der St. Gallischen Naturwissenschaftlichen Gessellschaft 1877-78: 511. 1880. Mittenothamnium versipoma (Hamp.) Cardot, Revue Bryologique 40: 22. 1913. TIPO: Brasil, Rio de Janeiro, Glaziou 9096 (Síntipo: BM Nos. BM000862447!, PC Nos. PC0695248, PC0709774, PC0709582, JE04008246). Syn. nov

Notas nomenclaturais: Os autores deste artigo optaram em não lectotipificar este nome, pois não foi possível estudar todas as duplicatas do material tipo. Das sete amostras do material tipo, apenas três exsicatas foram analisadas (todas de BM). As demais amostras encontram-se em PC e JE.

Mittenothamnium volvatum var. gracilius (Hampe) Wijk \& Margadant, Taxon 10: 25. 1961. Hypnum volvatum var. gracilius Hampe, Annales des Sciences Naturelles; Botanique, sér. 5, 5: 319. 1866. TIPO: Bogotá, Tequendama, Lindig (Holótipo: BM!). Syn. nov.

Plantas laxas foliadas, formando tapetes emaranhados, verde-olivas a verdeamareladas; ramos pouco complanados a julaceos. Caulídio estipitado, com a ramificação 1-3 pinada-ramificada, geralmente estreita a flageliforme no ápice. Filídios do estipe triangulares a ovalado-triangulares, 0.5-0.7x0.25-0.4 mm; filídios do caulídio patentes a esquarrosos, ovalado-lanceolados a triangular-ovalados, 0.45-1.3x0.4-0.8 mm; base curto-decurrente; margens serruladas na extremidade superior e serrulada a denticulada abaixo, costa curta e dupla, desigual, uma das forcas podendo ser maior que a outra; células lineares com papilas na porção superior; células alares quadradas a subquadradas em 1-5 fileiras; filídios da ramificação laxos, patentes a ereto-patentes, estreitamente lanceolados a ovalado-lanceolados, 0.4-0.95x0.3-0.55 mm; filídios jovens 
com ápice mais serrulado do que os filídios adultos; costa curta e dupla, desigual; células longo-hexagonais a linear-oblongas, com papilas apenas no ápice da célula; células alares quadradas a curto-retangulares, em 1-3 fileiras no extremo ângulo. Seta alongada, 2-3 cm comprimento, lisa, vermelha escura a amarelada. Cápsula curtocilíndrica, pendente, inclinada a horizontal. Opérculo cônico-rostrato. Esporo esférico, finamente papiloso, sob microscopia de luz, e apresentando grânulos sob microscopia eletronica de varredura (MEV), 10-17 $\mu \mathrm{m}$ diam. (Fig. 8). 

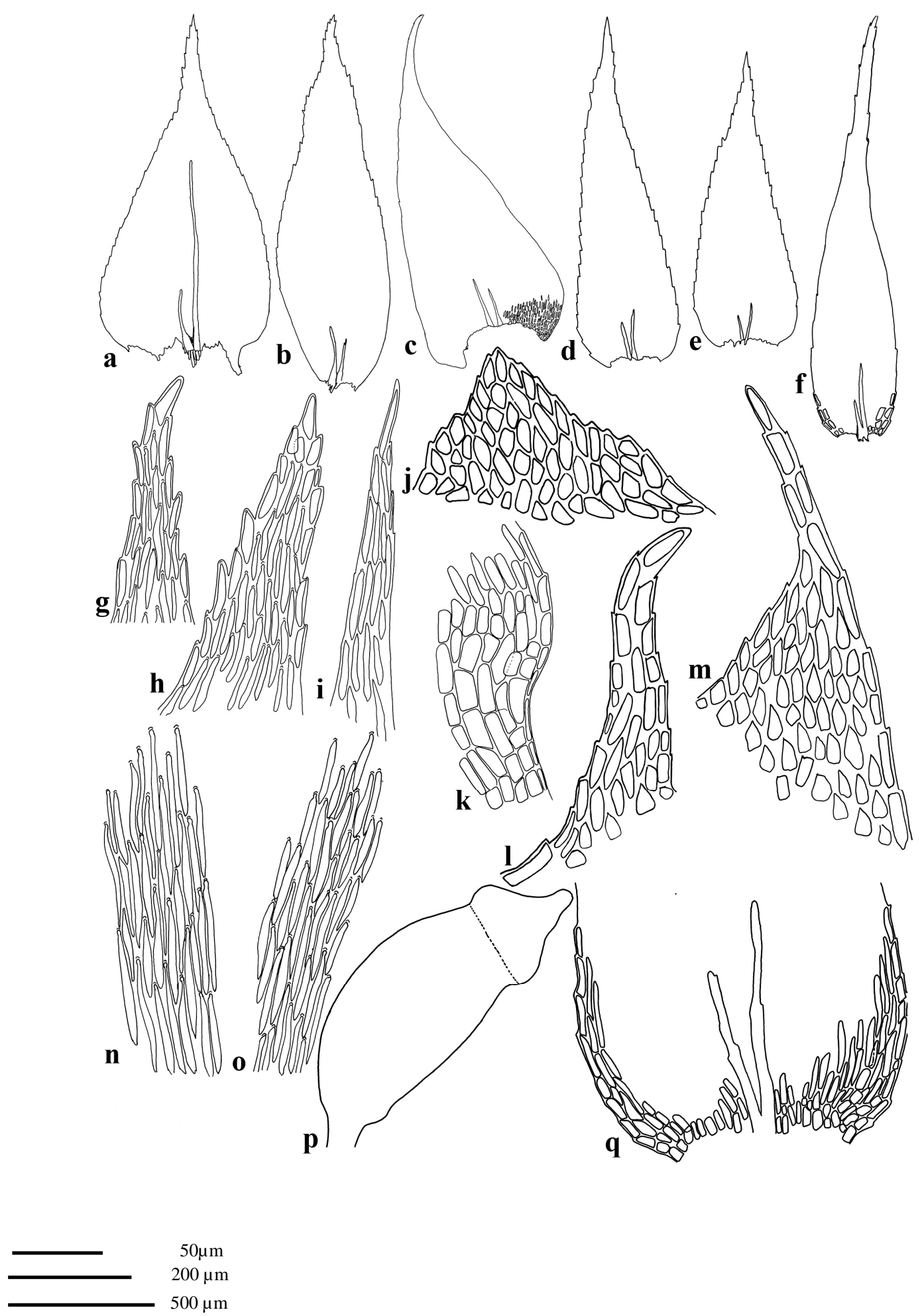

Figura 8. A-Q. Mittenothamnium reptans. A-C: Filídios do caulídio. D-F: Filídios da ramificação. G-H: Ápice filídios da ramificação. I: Ápice filídio do caulídio. J: Pseudoparáfilo. K: Células alares. L-M: Pseudoparáfilos. N-O: Células medianas do filídio do caulídio e ramos, respectivamente. P: Cápsula. Q: Base do filídio da

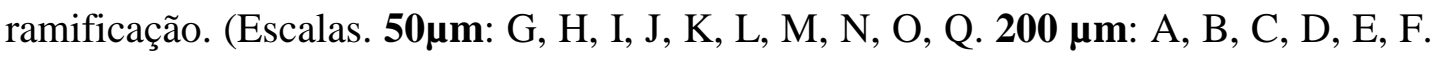
$\mathbf{5 0 0} \boldsymbol{\mu m}$ : P). Prancha: O. S. de Moura. 
Comentários: Mittenothamnium reptans é a espécie mais comum encontrada na região neotropical e, devido a sua ampla distribuição, a morfologia dos seus filídios pode variar bastante. É uma espécie extremamente variável no tamanho, modo da ramificação, forma e tamanho da cápsula. Os filídios jovens apresentam as margens mais serruladas que os filídios mais velhos (Buck 1998). Como observado acima, é uma espécie que apresenta muitas sinonimizações. Pode ser confundida com M. substriatum, mas diferencia-se por apresentar caulídio mais estipitado, filídios menores e margem dos filídios mais serruladas. Além disso, estudos moleculares (Moura \& Câmara, in. prep.) mostraram que essa espécie pertence ao gênero Mittenothamnium.

Distribuição e Habitat: Mittenothamnium reptans é encontrada em florestas tropicais, abertas, baixas, em florestas mésicas ou de neblina, usualmente lugares úmidos, em todos os tipos de substratos. A altitude vai desde o nível do mar até $3400 \mathrm{~m}$. Ocorre em praticamente toda região neotropical (Fig. 9), mas também é reportada para América do Norte, África, Europa e Ásia.

De acordo com os critérios da IUCN, a espécie de M. reptans não está ameaçada e apresenta status pouco preocupante (categoria LC). 


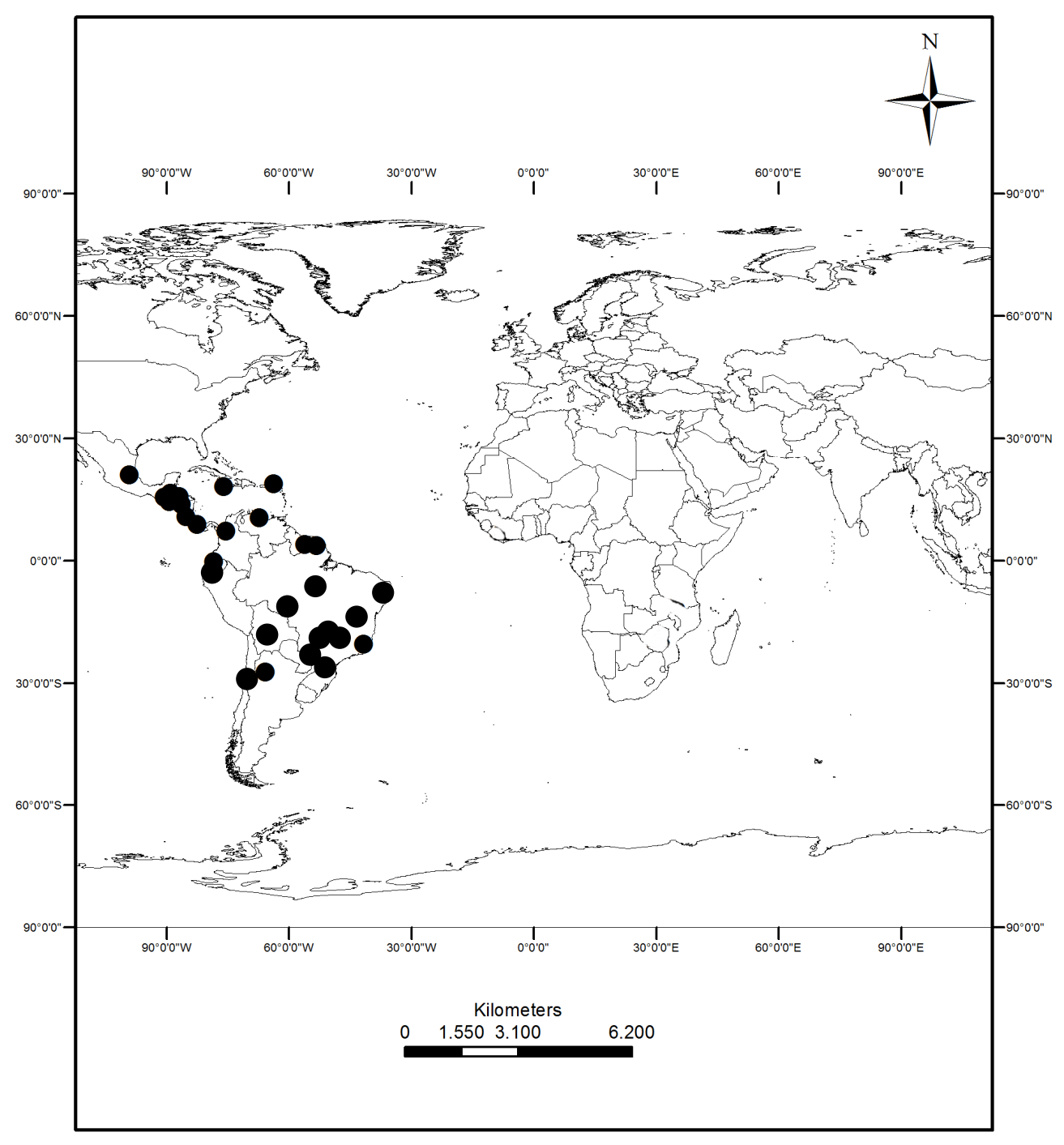

Figura 9. Mapa de distribuição de Mittenothamnium reptans.

Espécimes representativos examinados: BRASIL, Bahia, Ballejos 1857 (ALCB); Distrito Federal, Silva et al. 509 (UB); Goiás, Irwin et al. 33209 (UB); Mato Grosso do Sul, Silva 119 (UB); Minas Gerais, Peralta \& Marcelli 11672 (SP); Pará, Lisboa et al. 1776 (MG); Paraná, Ristown 1142 (SP); Pernambuco, Pôrto 2658 (UFP); Rio de Janeiro, Eiten \& Eiten 7492 (SP); Rondônia, Lisboa 3940 (MG). BOLÍVIA, Santa Cruz, Inturias et al. 723A (MO). HONDURAS, Guatemala, Schipp 1934 (NY). COSTA RICA, Alajuela, Brenes 19012 (NY). CUBA, Baracoa, Underwood \& Earle 1044 (NY). EQUADOR, Carchi, Mexia 7611a (NY). GUADELOUPE, Duss 35 (NY). GUATEMALA, Alta Verapaz, Johnson 572 (NY). GUIANA FRANCESA, St. Laurentdu-Maroni, Buck 25650 (NY). MÉXICO, Vera Cruz, Purpus 8127 (NY). PERU, 
Amazonas, Frahm et al. 1024 (NY). REPÚBLICA DOMINICANA, La Vega, Judd 1415 (NY).

4.6. MITTENOTHAMNIUM SALLEANUM (Besch.) Card., Revue Bryologique 40: 21. 1913. Hypnum salleanum Besch., Mém. Soc. Sci. Nat. Math. Cherbourg 16: 253. 1872. Microthamnium salleanum (Besch.) Besch. Index Bryologicus 811. 1897. Stereohypnum salleanum (Besch.) M. Fleish. Hedwigia 47: 274.1908. Mittenothamnium salleanum (Besch.) Card. Revue Bryologique 40: 21. 1913. Chrysohypnum salleanum (Besch.) W. R. Buck, Memoirs of The New York Botanical Garden 82: 335. 1998. TIPO: México, Cordova, Sallé s.n. (Síntipo: BM!).

Plantas formando geralmente extensos tapetes, verde-escuras a amareladomarrom. Caulídio rastejante a levemente arqueado, rijo, ramificação subpinada, com ramos frequentemente simples, delgados, atenuados, densamente foliados; pseudoparáfilo folhoso e triangular; secção transversal com 3-5 fileiras de pequenas células. Filídios do estipe pouco diferenciado, ovalados, com ápice curto acuminados, algumas vezes esquarrosos. Filídios do caulídio patente a esquarrosos, amplamente ovalados a ovalado-triangulares ou orbiculares a ovalado-lanceolados, 0.86-1.14x0.52$0.74 \mathrm{~mm}$; ápice curto acuminado; margens serruladas do ápice até próximo a base; costa curta e dupla, algumas vezes $1 / 2$ do tamanho do filídio; células medianas opacas, oblongo-lineares ou hexagonais, com papilas nas extremidades superiores; células alares subquadradas a retangular; pseudoparáfilo triangular-lanceolado com ápice acuminado e folhoso. Filídios dos ramos patentes, ereto-espalhados, lanceolado-ovalados, 1.341.36x0.38-0.46 mm; ápice gradualmente curto-acuminado; margens serruladas em toda extremidade; células longas hexagonais, densamente com papilas na porção superior; células alares pouco diferenciadas, quadradas; base cuneada. Seta até $3 \mathrm{~cm}$ de comprimento, avermelhada a marrom. Cápsula subereta a horizontal, oblongocilíndrica. Opérculo cônico rostelado. Esporos não observados. (Fig. 10). 

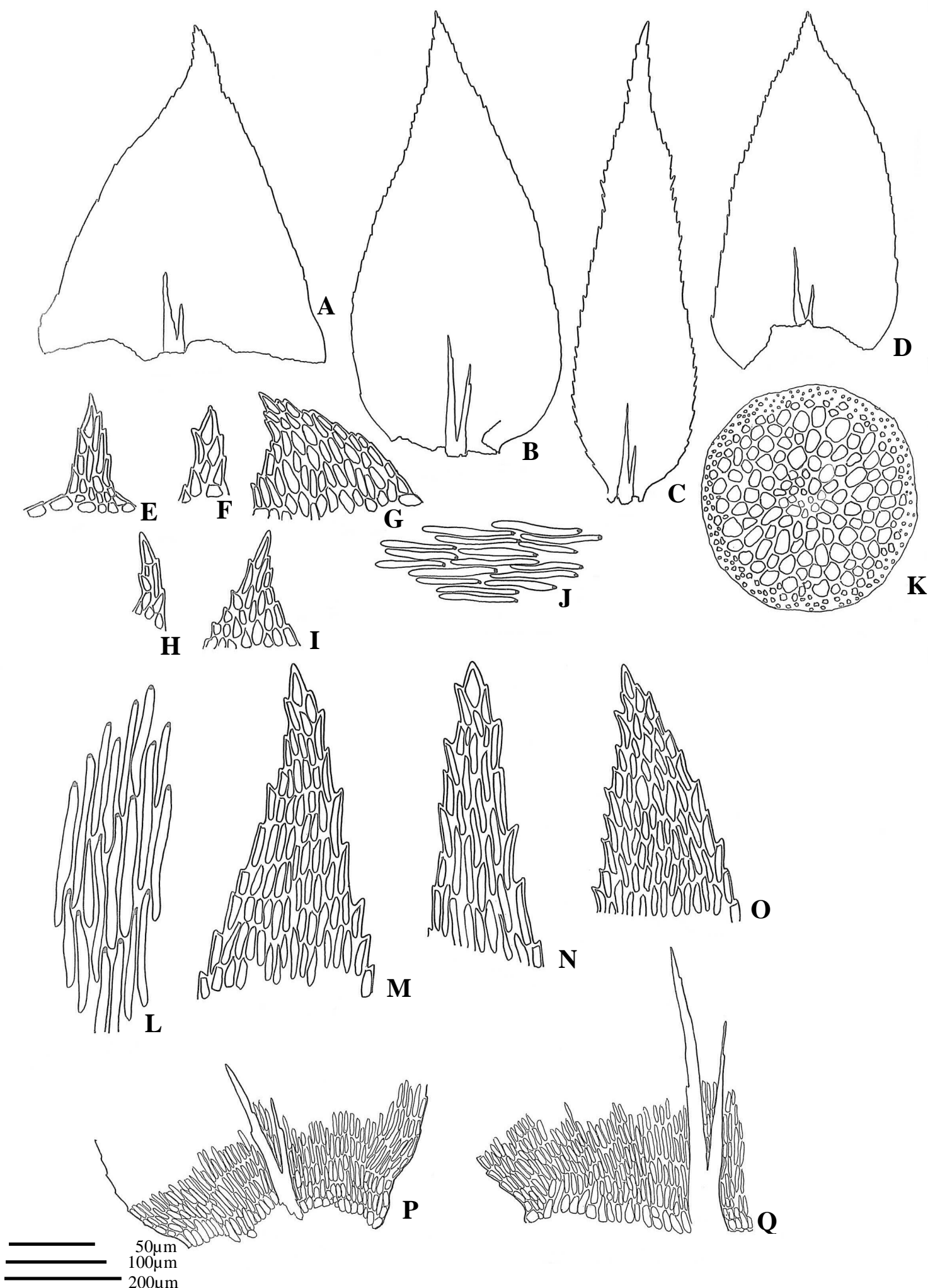

Figura 10. A-Q. Mittenothamnium salleanum. A-B: Filídios do caulídio. C-D: Filídios da ramificação. E-I: Pseudoparáfilos. J: Células medianas do filídio da ramificação. K: Corte transversal do caulídio. L: Células medianas do filídio do caulídio. M-O: Ápice do filídio do caulídio e ramos, respectivamente. P-Q: Base do filídio do ramos e caulídio, respectivamente. (Escalas. 50 $\mu \mathrm{m}$ : G, H, I, J, K, L, M, N, O, Q. 200 m: A, B, C, D, E, F. $500 \mu$ m: P). Prancha: O. S. de Moura. 
Comentários: Mittenothamnium salleanum é caracterizada por apresentar filídios do caulídio acuminados, amplamente ovalados a ovalado-lanceolados ou orbiculares. Buck (1998) tranferiu essa espécie para Chryso-hypnum, sugerindo que $M$. salleanum é considerado mais "superficialmente" próximo a Chryso-hypnum diminutivum do que com as demais espécies de Mittenothamnium, devido à presença de ramos túrgidos e densamente foliados. Mas, ele afirma que, apesar disso, os pêlos axilares de $M$. salleanum são mais parecidos com aqueles de $M$. reptans e $M$. substriatum do que com $C$. diminutivum. Os autores desse artigo confirmam que essa espécie apresenta certa complexidade, pois ela também apresenta pseudoparáfilo triangular e papilas apenas na porção superior da célula, características ímpar de Mittenothamnium.

Distribuição e habitat: Essa espécie ocorre em ambientes úmidos, sombreados a parcialmente sombreados, em tronco vivo, tronco em decomposição e em rochas, próximo a córregos (Buck 1998). A altitude é abaixo de $1000 \mathrm{~m}$. O único material visto dessa espécie, pelos autores, foi um dos síntipos, cuja localização da amostra é do México. Mas, Buck (1998) afirma que pode ocorrer também em Belize, Honduras e Cuba (Fig. 11).

De acordo com os critérios da IUCN, Mittenothamnium salleanum apresenta dados insuficientes (categoria DD), por não apresentar informações adequadas para ser avaliada.

Espécimes representativos examinados: conhecida apenas pelo tipo: MÉXICO, Cordova, Sallé 17 (NY). 


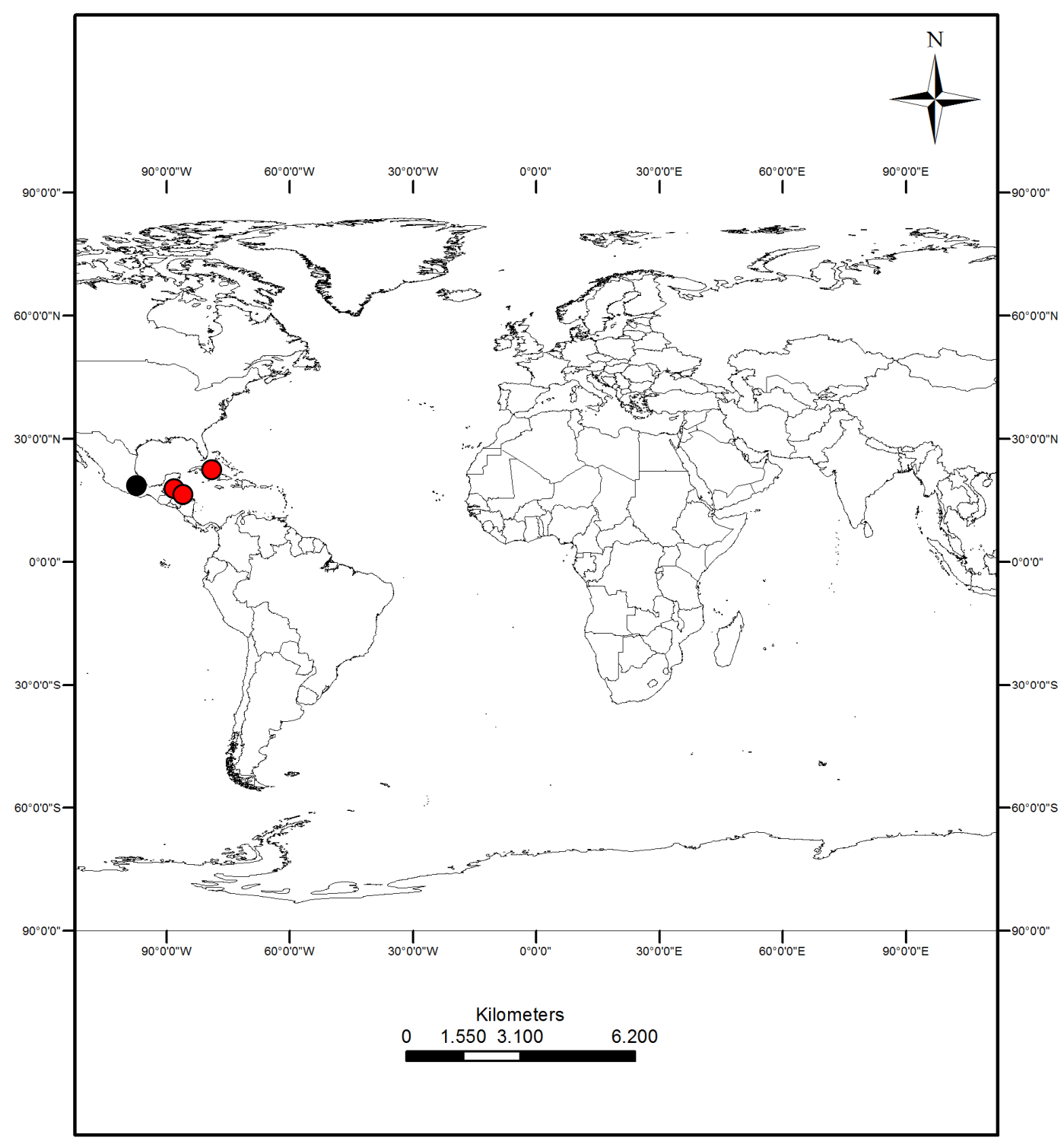

Figura 11. Mapa de distribuição de Mittenothamnium salleanum. Amostra observada (círculo preto) e amostras não observadas (círculo vermelho).

4.7. MitTENOTHAMNIUM SCALPELLIFOLIUM (Müll. Hal.) H. A. Crum, Advancing Frontiers of Plant Sciences 21: 193. 1968. Microthamnium scalpellifolium Müll. Hal., Bulletin de l'Herbier Boissier 5: 214. 1897. Isopterygium scalpellifolium (Müll. Hal.) Broth., Die Natürlichen. Pflanzenfamilien. I(3): 1080. 1908. Taxiphyllum scalpellifolium (Müll. Hal.) Broth. Die natürlichen Pflanzenfamilien, Zweite Auflage 11: 462. 1925. Plagiothecium scalpellifolium (Müll. Hal.) E. B. Bartram, The 
Bryologist 49: 122. 1946. TIPO: Guatemala, Mazatenango, Benoulli 82 (Holótipo: B, provavelmente destruído, Isótipo: PC!).

Plantas amarelado-esverdeadas a amarelado-marrons, formam pequenos tapetes emaranhados. Caulídio arqueado-ascendente a partir do ramo primário; ramos curvados para baixo, fortemente complanado-foliados. Filídios do estipe patentes a esquarrosos, triangular-lanceolados; ápice curto-acuminado. Filídios do caulídio ereto, com ápice curto-acuminado, côncavo, ovalados a ligulados, 0.54-0.62x0.18-0.21 mm; margens sub-inteiras acima e distantemente serreada abaixo, involutas; costa curta e dupla; células lineares, inconspicuamente com papilas na porção superior; células alares pouco diferenciadas, curto-retangulares; pseudoparáfilo triangular e folhoso. Filídios dos ramos fortemente complanados, estreitamente ovalados a ligulados, com 0.750.90x $0.28-0.31 \mathrm{~mm}$, semelhantes aos do caulídio no formato e margem; costa curta e dupla, até $1 / 4$ do tamanho do filídio; células lineares, curta a romboidal em direção ao ápice, com papilas apenas parte superior; células alares curto-retangulares. Seta alongada, lisa, avermelhada, ca. de 1,2-1,7 cm de comprimento. Cápsula horizontal, assimétrica, curto-cilíndrica; células do exotécio levemente isodiamétrica. Opérculo cônico rostrado. Esporos e caliptra não observados. (Fig. 12). 

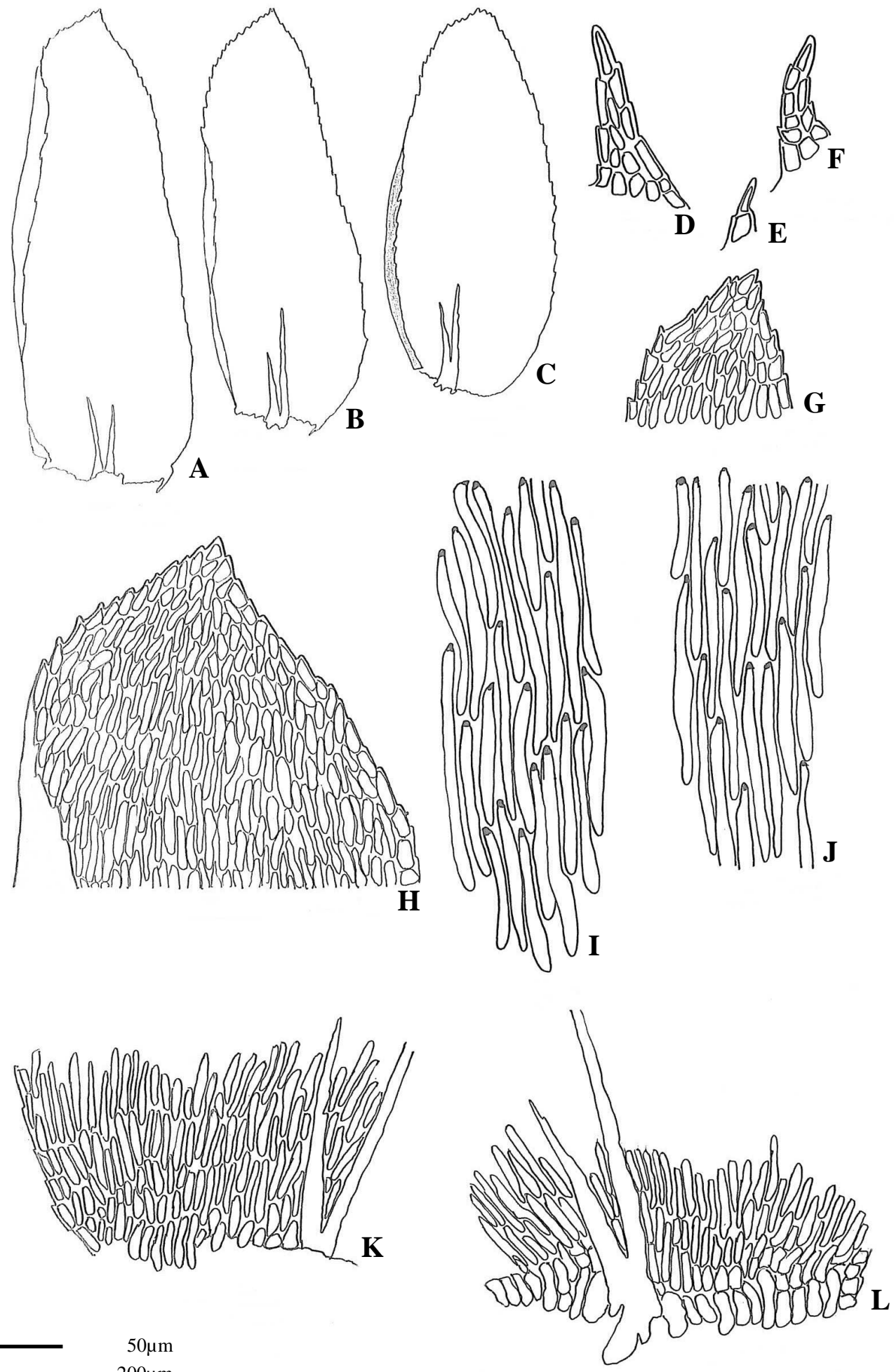

Figura 12. A-Q. Mittenothamnium scalpellifolium. A: Filídio do caulídio. B-C: Filídios da ramificação. D-F: Pseudoparáfilos. G-H: Ápice filídio da ramificação e caulídio, respectivamente. I-J: Células medianas do filídio do caulídio e ramos, respectivamente. K-L: Base do filídio do caulídio e ramos, respectivamente.

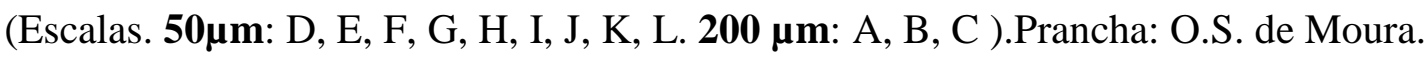


Comentários: Mittenothamnium scalpellifolium é facilmente reconhecida por apresentar ramos fortemente complanados-foliados com filídios estreitamente ovalados a ligulados, com ápice curto-acuminado. É considerada incomum em alguns lugares como no Caribe, conhecida apenas por poucas coleções. Já teve inúmeros sinônimos tendo sido tratada como Plagiothecium e Taxiphyllum por muitos autores. Mas foi separada destes gêneros por apresentar hábito estipitado. Buck (1998) sinonimizou essa espécie para Taxiphyllum baseado nas seguintes características: plantas fortemente complanadas, pêlos axilares, que são muito diferentes daquelas em Mittenothamnium. M. scalpellifolium, no entanto, apresenta características como filídios dos ramos e caulídios diferenciados, células da lâmina com papilas apenas na porção superior e caule estipitado. Além disso, estudos moleculares (Moura \& Câmara, in. prep.) mostraram que essa espécie pertence ao gênero Mittenothamnium.

O material tipo dessa espécie provavelmente foi destruído no herbário de Berlin (Sayre 1977), mas o isótipo encontra-se no herbário PC. No entanto, neste trabalho o material do B foi considerado holótipo por ser o herbário do primeiro autor.

Distribuição e Habitat: Essa espécie pode ser encontrada em florestas úmidas, sobre tronco vivo, rocha, solo, 500-2000 m. É reportada para Guatemala, Colômbia, Cuba, Jamaica, Republica Dominicana (Buck 1998, Sharp et al., 1994). Contudo, os autores observaram apenas as amostras de Belize, Honduras, Nicarágua e Panamá (Fig. 13).

De acordo com os critérios da IUCN, essa espécie não está ameaçada e apresenta status pouco preocupante (categoria LC). 


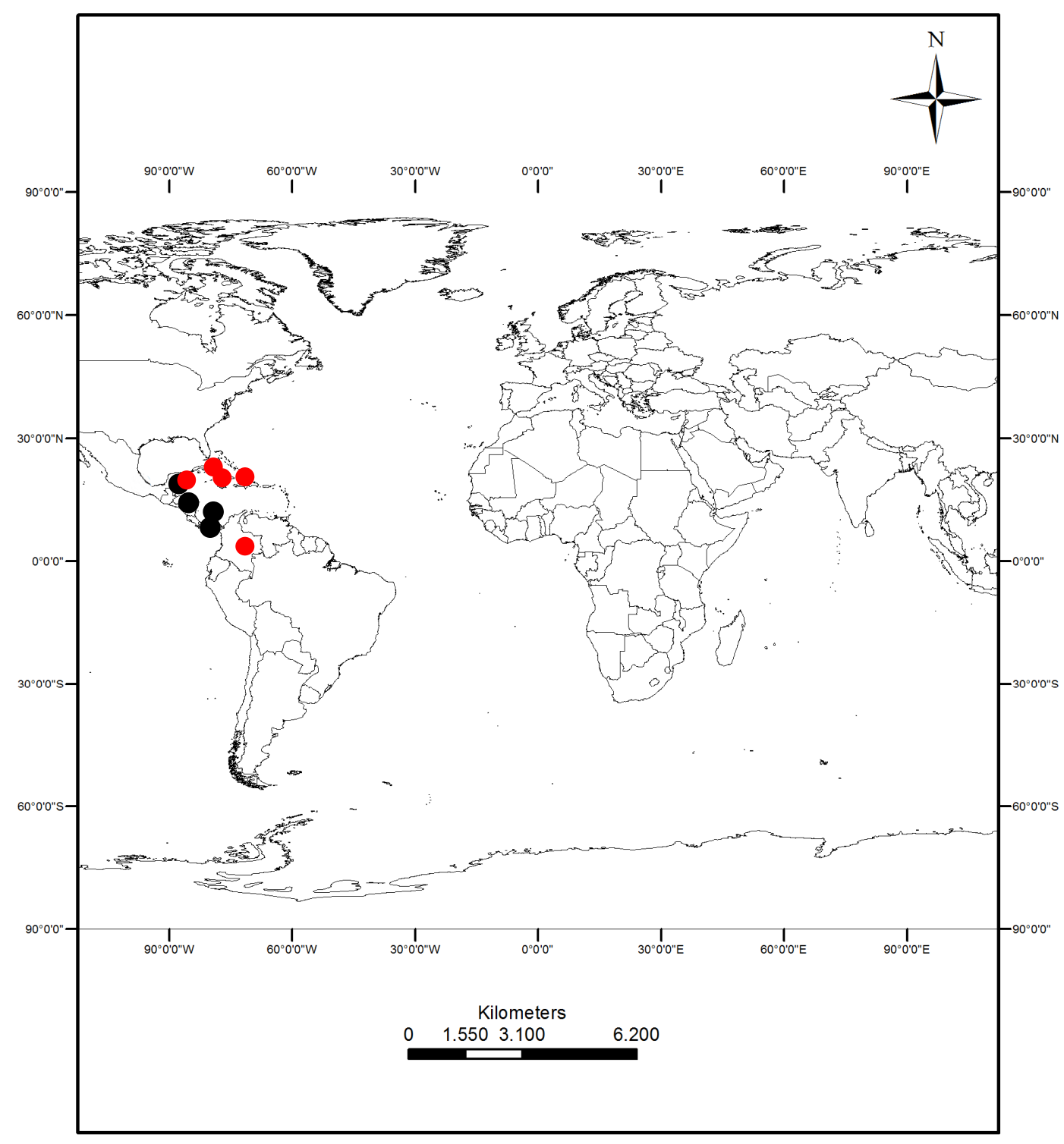

Figura 13. Mapa de distribuição de Mittenothamnium scalpellifolium. Amostras observadas (círculos pretos), material não observado (círculos vermelhos).

Espécimes representativos examinados: BELIZE, Cayo, Allen 18288 (MO); Toledo, Whittemore 5608 (MO). COLÔMBIA, Magdalena, C et al., 16494-b (NY). HONDURAS, Atlântida, Allen 17449 (MO). PANAMÁ. Darien, Allen 8739 (MO). NICARÁGUA, Chontales, Magill 14642 (MO). 
4.8. MITTENOTHAMNIUM SUBSTRIATUM (Mitt.) Cardot, Revue Bryologique 40: 21. 1913. Microthamnium substriatum Mitten, Journal of the Linnean Society, Botany 12: 504. 1869. Stereohypnum substriatum (Mitt.) M. Fleischer, Hedwigia 47: 274. 1908. TIPO: Equador, Monte Tunguragua e Baños, Spruce 360 (Lectótipo: NY!, Designado aqui).

Plantas densamente foliadas, rígidas, geralmente douradas, formando pequenos tapetes. Caulídio ereto, 1-3 pinado, pouco diferenciado do estipe, densamente foliado, atenuado. Filídios do estipe pouco diferenciados, ovalados, $1.5-1.7 \mathrm{~mm}$ de comprimento, gradualmente acuminado. Filídios do caulídio eretos, lanceoladoovalados, 1.7-2.5x0.7-.091 mm, gradualmente acuminado, irregularmente plicados, base pouco decurrente ou não; margens serruladas acima, inteira a pouco serrulada abaixo; costa curta e dupla, desigual, onde uma das forquilhas apresenta $1 / 3$ do tamanho do filídio; células lineares a linear-oblongas, com papilas na porção superior; células alares subquadradas a curto-retangulares em 2-5 fileiras; pseudoparáfilo triangular-lanceolado. Filídios dos ramos eretos, lanceolados a ovalado-lanceolados, 1.95-2.25x0.81-0.98 mm; ápice gradualmente acuminado; margens serruladas até próximo a base; costa curta e dupla, desigual, onde uma das forquilhas varia de $1 / 4-1 / 3$ o comprimento do filídio; células lineares pouco papilosas na extremidade superior; células alares poucas, curtoretangulares, 1-3 fileiras. Seta alongada, lisa, vermelho-escura, 2-3 cm de comprimento, levemente retorcida. Cápsula inclinada à pendente, assimétrica, cilíndrica. Opérculo cônico-rostrato. Esporos esféricos, finamente papilosos. (Fig. 14). 


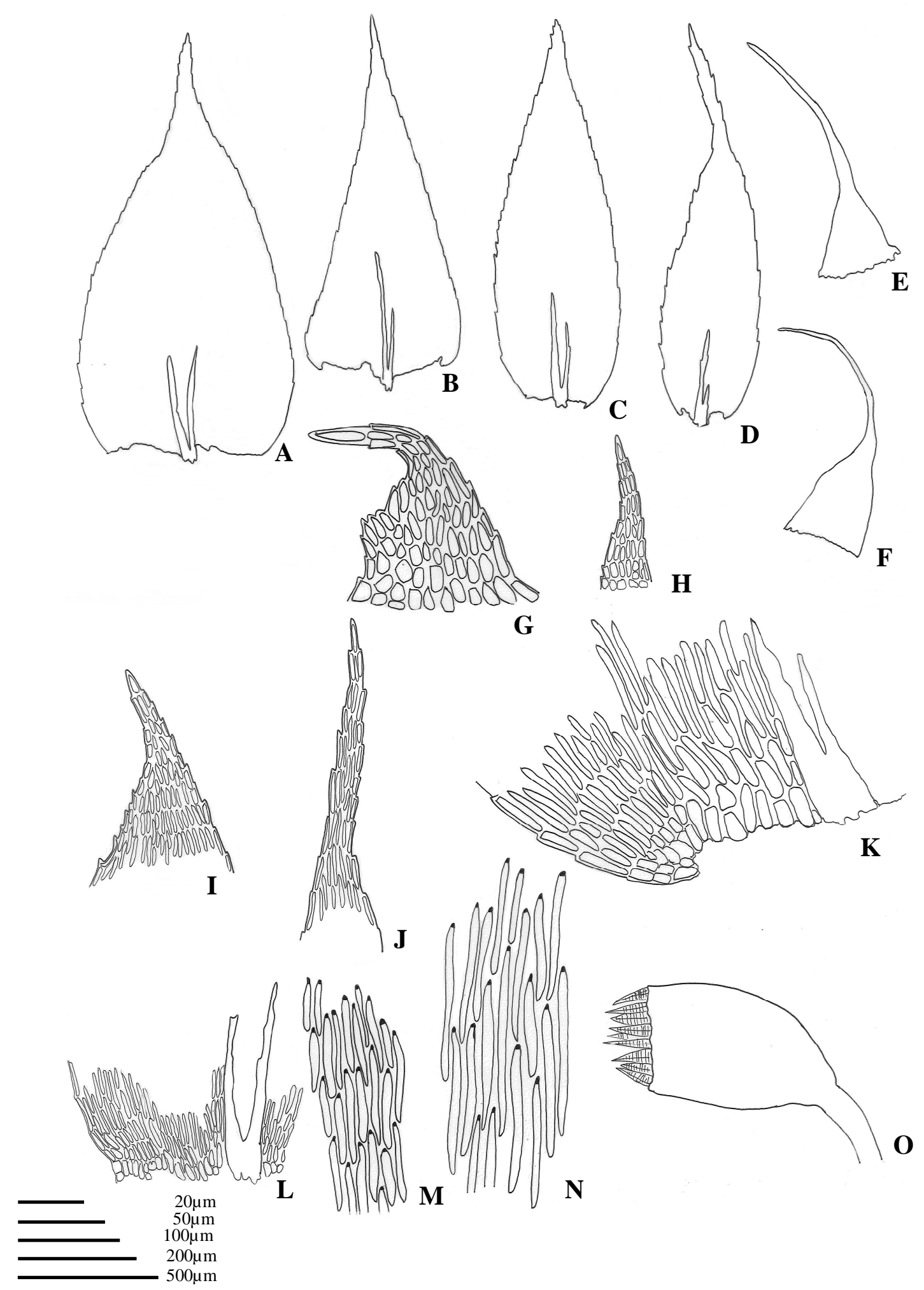

Figura 14. A-O. Mittenothamnium substriatum. A-B: Filídios do caulídio. C-D: Filídios da ramificação. E-F: Filídios do periquécio. G-H: Pseudoparáfilos. I-J: Ápice filídio do caulídio e ramos, respectivamente. K-L: Base do filídio do caulídio e ramos, respectivamente. M-N: Células medianas dos filídios dos ramos e caulídio, respectivamente. O: Cápsula. (Escalas. $20 \mu \mathrm{m}$ : N. 50 $\mu \mathrm{m}: \mathrm{G}, \mathrm{K}, \mathrm{M} . \mathbf{1 0 0 \mu \mathrm { m } : ~ H , ~ I , ~ J , ~}$

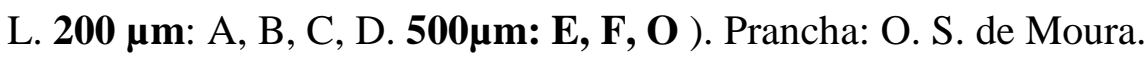


Comentários: Mittenothamnium substriatum pode ser confundida com $M$. reptans, diferenciando-se deste por apresentar filídios maiores, cor dourada, hábito estipitado menos observado e filídios com a margem menos serrulada. M. substriatum já foi chamado de M. langsdorffii (Hook.) Cardot, na brioflora da Jamaica (Crum \& Bartram 1958). No entanto, essa última espécie é sinônimo de M. reptans.

Além disso, dados moleculares (Moura \& Câmara, in. prep.) sugerem que essa espécie pertence ao gênero Mittenothamnium.

Distribuição e Habitat: Cresce sobre tronco em decomposição, solo, rochas e base de tronco vivo; encontrada em florestas úmidas e pastagens, em bosques montano, 1180-3320 m.. Essa espécie pode ser encontrada na Bolívia, Colômbia, Costa Rica, Equador, Honduras, Nicarágua e Peru (Fig. 15). Mas, Buck (1998) apresenta registros dessa espécie também na Jamaica e República Dominicana.

De acordo com os critérios da IUCN, essa espécie não está ameaçada e apresenta status pouco preocupante (categoria LC). 


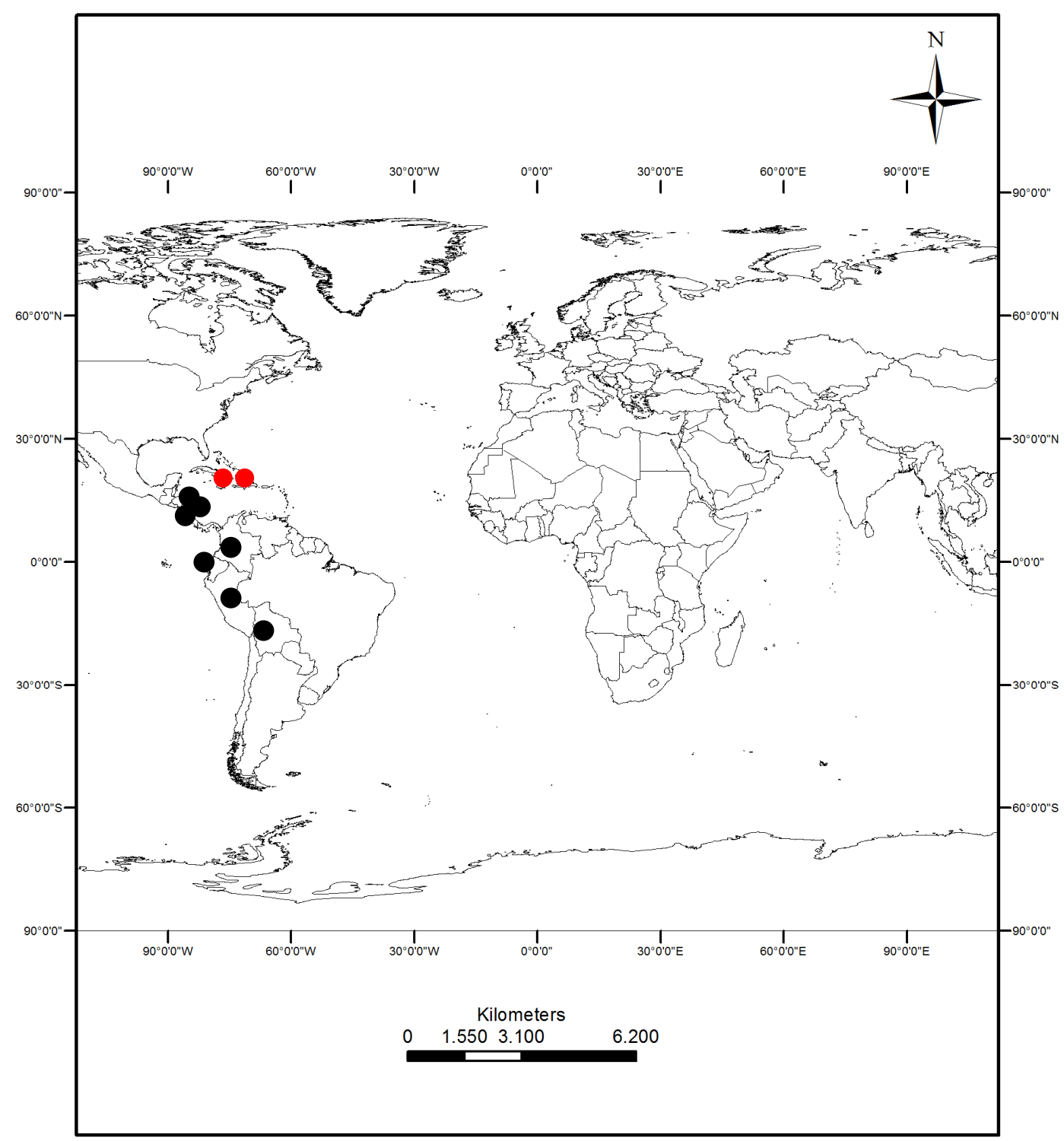

Figura 15. Mapa de distribuição de Mittenothamnium substriatum. Amostras observadas (círculos pretos), não observadas (círculos vermelhos).

Espécimes representativos examinados: BOLÍVIA, Tarija, Apaza et al. 90 (MO). COLÔMBIA, Darien, Churchill \& Lynch 19436 (MO); Nariño, Ramírez 2882 (NY). COSTA RICA, Cartago, King C91-76 (MO). EQUADOR, Zamora-Chinchipe, Churchill et al. 24503 (MO). HONDURAS, Lempira, Allen 11577 (MO); Yuncker et al. 6610 (NY). NICARÁGUA, Estelí, Cerda GC-1587 (MO). PERU, Pasco, Opisso et al. $1802(\mathrm{MO})$. 


\section{Tipos não vistos}

5.1. Mittenothamnium burelae (Herzog) F. J. Hermann, The Bryologist 79: 159. 1976. Stereohypnum burelae Herzog, Beihefte zum Botanischen Centralblatt. Zweite Abteilung, Systematik, Pflanzengeographie, angewandte Botanik 26(2): 84. 1909. TIPO: Bolívia, Herzog s.n. (Holótipo: JE).

O material tipo foi solicitado pelos autores ao herbário de JE, onde está depositado o material coletado pelo autor, mas sem sucesso. A obra original não foi localizada. Logo, não há evidências de que esse material seja a espécie Mittenothamnium burelae ou sinônimo de outra espécie de Mittenothamnium.

5.2. Mittenothamnium limosum (Besch.) Cardot, Revue Bryologique 40: 21. 1913. Microthamnium limosum Bescherelle, Annales des Sciences Naturelles; Botanique, sér. 6, 10: 313. 1880. TIPO: La Reunión, De l’Ilse s. $n$. (Holótipo: BM).

Coletas de Bescherelle encontram-se depositadas principalmente nos herbários de BM, PC, Contudo, não foi encontrado nenhum material typus dessa espécie. A descrição original diz que a planta apresenta características semelhantes à $M$. reptans, como filídios ovalado-lanceolados, costa dupla, margem serrulada, filídios do periquécio longo acuminados. Além disso, essa espécie apresenta como sendo distribuída em Madagascar e La Reunión, onde Mittenothamnium reptans também ocorre. Dessa maneira, os autores deste trabalho sugerem que essa espécie pode ser Mittenothamnium reptans.

5.3. Mittenothamnium mycostelium (Hampe) Cardot, Revue Bryologique 40: 21. 1913. Hypnum mycostellium Hampe, Videnskabelige Meddelelser fra Dansk Naturhistorisk Forening i Kjøbenhavn ser. 4, 1: 142. 1879. Ectropothecium mycostelium (Hampe) Paris, Index Bryologicus 408. 1896. Isopterygium mycostelium (Hampe) Kindberg, Enumeratio Bryinearum Exoticarum, supplementum 2, 100. 1891. Microthamnium mycostelium (Hampe) Brotherus, Die Natürlichen Pflanzenfamilien I(3): 1049. 1908. TIPO: Brasil, Lagoa Santa, Warming s.n. (Holótipo: BM).

O material tipo foi solicitado pelos autores ao herbário de $\mathrm{BM}$, onde se depositou o material descrito pelo autor, mas sem sucesso. Na obra original Hampe (1879), faz uma breve descrição, sem ilustração, dessa espécie como filídios do caulídio 
ovalado-lanceolados, ápice acuminado, margens ereta serruladas, células subretangulares lineares; filídios dos ramos semelhantes aos do caulídio; seta pequena, cápsula horizontal obovada e opérculo cônico, características essas que se assemelham a Chryso-hypnum.

5.4. Mittenothamnium plinthophilum (Müll. Hal.) Cardot, Revue Bryologique 40: 21. 1913. Hypnum plinthophillum Müll. Hal., Linnaea 42: 438. 1879. Microthamnium plinthophillum (Müll. Hal.) Paris, Index Bryologicus 810. 1897. TIPO: Argentina, Estancia Lascano, Lorentz 27 (Holótipo: B).

Materiais coletados por Müller foram destruídos em B e não foram encontrados isótipos deste material nos outros herbários investigados. O autor, Müller (1879), descreve essa espécie como apresentando filídios do caulídio patentes ovalados, ápice acuminado, costa dupla, células do filídio pequenas; cápsula avermelhada inclinada, ovalada; opérculo cônico obtuso-mucronulado. Tais características morfológicas não são encontradas em nenhuma espécie de Mittenothamnium.

5.5 Mittenothamnium sellovii (Hornsch.) Cardot, Revue Bryologique 40: 21. 1913. Hookeria sellovii Hornschuch, Flora Brasiliensis 1(2): 66. 1840. Microthamnium sellovii (Hornsch.) Mitten, Journal of the Linnean Society, Botany 12: 507. 1869. TIPO: Brasil, Sellow s.n. (Holótipo: B).

Os materiais de Hornschuch também foram destruídos em $\mathrm{B}$ e não foram encontrados isótipos deste material nos outros herbários investigados. Na obra original (Hornschuch 1840), o autor não coloca imagens do táxon, mas descreve como características morfológicas para esta espécie filídios do caulídio patentes, lanceolados a ovalado-lanceolados, ápice curto acuminado, margens serruladas; células da lâmina lineares; seta ereta alongada; opérculo cônico rostrado; cápsula inclinada, pendente. Assim, pela descrição original, $M$. sellovii parece ser sinônimo de $M$. reptans.

5.6. Mittenothamnium tapes (Müll. Hal.) Cardot, Revue Bryologique 40: 21. 1913. Microthamnium tapes Müller, Hedwigia 36: 137. 1897. Stereohypnum tapes (Müll. Hal.) M. Fleischer, Hedwigia 47: 274. 1908. TIPO: Argentina Subtropica, Chaco, Lorentz, s.n. (Holótipo: B). 
Materiais de Müller foram destruídos em B e não foram encontrados isótipos desse material nos demais herbários investigados. A descrição original é em grande parte confusa, não havendo ilustração disponível. No entanto, Müller descreve algumas características semelhantes à Mittenothamnium scalpellifolium, como plantas apresentando filídios oblongo-lanceolados, margem ereta em toda parte, serrulada no ápice. Além disso, M. tapes ocorre na Argentina, próximo a Honduras e México, locais estes, de ocorrência de M. scalpellifolium. No entanto, tais características não são suficientes para sinonimizá-los.

\section{Nomes inválidos}

Mittenothamnium apresenta uma lista com um vasto número de espécies, totalizando 151 espécies entre nomes legítimos, inválidos, ilegítimos e duvidosos. Isso acontece por muitas vezes o nome não estar de acordo com o Código de Nomenclatura ou por não apresentar descrição do material examinado na obra publicada ou por não apresentar localização do material. A seguir uma lista com os nomes considerados inválidos e ilegítimos:

6.1. Mittenothamnium sect. Eu-mittenothamnium Thériot, Memorias de la Sociedad Cubana de Historia Natural "Felipe Poey" 15: 229. 1941. Esse nome é inválido segundo Art. 21.3 and Art. 22.2 do Código de Melbourne (McNeill 2012).

6.2. Mittenothamnium brachysteliophilum Cardot, Revue Bryologique 40: 20. 1913. É um nome inválido, não apresenta descrição.

6.3. Mittenothamnium epruinosum Cardot, Revue Bryologique 40: 21. 1913. Esse nome é inválido por não apresentar descrição.

6.4. Mittenothamnium nicaraguense Brotherus, Torreya 14: 30. 1914. Nome inválido, não apresenta descrição.

6.5. Mittenothamnium trichostegium Cardot, Revue Bryologique 40: 21. 1913. Nome inválido, não apresenta descrição. 
6.6. Mittenothamnium uleanum Cardot, Revue Bryologique 40: 21. 1913. Nome ilegítimo onde o nome do tipo foi incluindo com base na adoção do epíteto anterior: Microthamnium uleanum Thér.

6.7. Mittenothamnium variflexum Hampe, Bericht über die Thätigkeit der St. Gallischen Naturwissenschaftlichen Gesellschaft 1876-77: 430. 1878. Nome inválido, não apresenta descrição.

\section{Sinonimizações de algumas espécies de Mittenothamnium para outros gêneros.}

\subsection{Campylium chrysophyllum (Brid.) Lange.}

Basiônimo: Hypnum chrysophyllum Brid., Muscologia Recentiorum 2(2): 84-85, pl. 2, f. 2. 1801. Hypnum stellatum var. chrysophyllum (Brid.) Drumm. Musci Americani; or, Specimens of the Mosses Collected in British North America 185. 1828. Hypnum polymorphum var. chrysophyllum (Brid.) Schimp. Bryologia Europaea 6: 89.583 (fasc. 57-61 Mon. 15. 3). 1854. Amblystegium chrysophyllum (Brid.) De Not., Atti della R. Università Genova 1: 148. 1869. Hypnum stellatum subsp. chrysophyllum (Brid.) Dixon, he Student's Handbook of British Mosses 455. 1896. Chrysohypnum chrysophyllum (Brid.) Loeske, Moosflora des Harzes 303. 1903. Campyliadelphus chrysophyllus (Brid.) R. S. Chopra, Tax. Indian Mosses.1975, comb. inval., Kanda, J. Journal of Science of the Hiroshima University, Series B, Division 2 (Botany) 15(2): 264. 1975[1976].

=Microthamnium ekmanii Thér., Travaux Bryologiques dediés à la Mémoire de PierreTranquille Husnot 2[14]: 22. 12. 1944. Mittenothamnium ekmanii (Thér.) H. A. Crum \& Steere, American Midland Naturalist 60: 49. 1958. Tipo: Hispaniola, Ekman 7661 (Holótipo: PC, Isótipo: NY!).

Notas nomenclaturais: Uma amostra do material tipo de Mittenothamnium ekmanii foi analisado em 1985 por Willian R. Buck, sendo por ele identificada como Campylium chrysophyllum. Assim, Buck (1993) em sua publicação sobre os musgos 
pleurocárpicos da Índia Ocidental transferiu Mittenothamnium ekmanii para Campylium chrysophyllum.

\subsection{Ectropothecium saproadelphus (Broth.) Moura, Comb. nov.}

Basiônimo: Microthamnium saproadelphus Broth., Botanische Jahrbücher für Systematik, Pflanzengeschichte und Pflanzengeographie 24: 262. 1897. Mittenothamnium saproadelphus (Broth.) Card., Revue Bryologique 40: 21. 1913. Tipo: África, Camarão, Dusén 499, Jungner 96 (Holótipo: H, Síntipo: NY!, PC).

Notas nomenclaturais: O holótipo de Mittenothamnium saproadelphus deveria estar no herbário H, onde as coletas de Brotherus se encontram (Sayre 1977), no entanto, os autores deste artigo não encontraram a amostra online disponível nesse herbário. Mas no herbário de NY dois síntipos foram analisados pelos autores em 2015, sendo identificados como Ectropothecium (que apresenta como características plantas pinadas com filídios falcado-secundos, células alares insuficientes e cápsula curta e ovóide), concordando com Willian R. Buck, que em 1993 analisou as mesmas amostras e identificou como sendo Ectropothecium. No entanto, Buck não faz menção desse sinônimo em nenhuma de suas publicações posteriores a esse ano. Dessa maneira, os autores aqui, resolveram sinonimizar essa espécie de Mittenothamnium saproadelphus para Ectropothecium saproadelphus de acordo com o material tipo analisado.

Também não foi possível lectotipificar essas amostras, pois existem outros síntipos nos herbários de PC, os quais não foram disponibilizados para observação.

\subsection{Isopterygium puiggarii (Geh. \& Hamp.) Moura, Comb. nov}

Basiônimo: Hypnum puiggarii Geh. \& Hamp., Videnskabelige Meddelelser fra Dansk Naturhistorisk Forening i Kjøbenhavn ser. 4, 1: 146. 1879. Microthamnium puiggarii (Geh. \& Hamp. ) Kindb., Enumeratio Bryinearum Exoticarum, supplementum 2, 101. 1891. Stereohypnum puiggarii (Geh. \& Hamp.) M. Fleischer, Hedwigia 47: 274. 288. 1908. Mittenothamnium puiggarii (Geh. \& Hamp.) Card., Revue Bryologique 40: 21. 1913. Tipo: Brasil, São Paulo, Puiggari 27, 418 (Lectótipo: BM!, Isolectótipo: BM!, PC, JE). 
Notas nomenclaturais: De todas as quatro amostras do material tipo analisadas, observou-se que Mittenothamnium puiggarii na verdade trata-se de Isopterygium puiggarii. Os autores optaram em não lectotipificar essas amostras, pois não foi possível analisar as demais exsicatas presentes nos herbários de PC e JE.

M. puiggarii foi transferida para Isopterygium, pelos autores deste trabalho, por apresentar caulídio irregularmente ramificado, complanado, margens do filídios inteiras ou serruladas apenas no ápice, características essas pertencentes ao gênero Isopterygium. Pode ser confundido com Ectropothecium, mas diferencia-se deste por apresentar cápsulas curto-cilíndricas.

\subsection{Rhacopilopsis trinitensis (Müll. Hal.) Moura,}

Basiônimo: Hypnum trinitensis Müll. Hal., Synopsis Muscorum Frondosorum omnium hucusque Cognitorum 2: 284. 1851. Ectropothecium trinitensis (Müll. Hal.) Mitt., Journal of the Linnean Society, Botany 12: 514. 1869. Dimorphella trinitensis (Müll. Hal.) Herzog, Arquivos de Botânica do Estado de São Paulo 1(2): 86. 1924. Tipo: Trinidad \& Tobago, Monte Tochuche, Crüger s.n. (Holótipo: B, provavelmente destruído, Isótipo: NY, BM).

=Microthamnium stuhlmannii Broth., Botanische Jahrbücher für Systematik, Pflanzengeschichte und Pflanzengeographie 20: 205. 1894. Mittenothamnium stuhlmannii (Broth.) Card., Revue Bryologique 40: 21. 1913. Tipo: África, Tanzânia, Stuhlmann 1074 (Holótipo: H, Isótipo: NY!). Syn. nov.

Notas nomenclaturais: O material tipo de Mittenothamnium stuhlmannii foi analisado por Buck (1993), sendo identificado como Acanthocladiella. No entanto, esse gênero foi transferido para Rhacopilopsis por Renauld \& Cardot (1900). Essa espécie pode ser confundida com Mittenothamnium, mas diferencia-se deste por apresentar células dos filídios lisas, prosenquimatosas e filídios dimórficos (lateral e ventral diferenciados).

7.5. Wijkia caudiforme (Müll. Hal.) Moura, Comb. nov. 
Basiônimo: Hypnum caudiforme Müll. Hal., Flora 69: 524. 1886. Microthamnium caudiforme (Müll. Hal.) Kindb., Enumeratio Bryinearum Exoticarum, supplementum 2, 101. 1891. Mittenothamnium caudiforme (Müll. Hal.) Card., Revue Bryologique 40: 21. 1913.. Tipo: África, Danckelmann s.n. (Holótipo: B, possivelmente destruída, Isótipo: $\mathrm{PC} !)$.

Notas nomenclaturais: Ao analisar o material tipo da espécie Mittenothamnium caudiforme, os autores evidenciaram que se trata de Wijkia e não Mittenothamnium, por apresentar características para o gênero como filídios do caulídio côncavos, ramos flagelifomes, margem inteira e células alares dividindo-se em pequenas células hialinas em direção a margem do filídio. Além disso, essa espécie tratada anteriormente como M. caudiforme apresenta células infladas, característica de Sematophyllaceae.

\section{Novas combinações para espécies excluídas de Mittenothamnium}

Todas as espécies, citadas aqui como novas combinações para Chryso-hypnum, apresentam como características principais, caulídio não estipitado, pseudoparáfilo filamentoso, às vezes folhoso e papilas em ambas as extremidades das células. Características essas que definem o gênero Chryso-hypnum o qual está sendo feito uma revisão taxonômica para o neotrópico (artigo in. prep.).

\subsection{Chryso-hypnum aptychela (Broth.) Moura, Comb. nov.}

Basiônimo: Microthamnium aptychela Brotherus, Bihang till Kongliga Svenska Vetenskaps-Akademien Handling 21 Afd. 3(3): 58. 1895. Mittenothamnium aptychela (Broth.) Cardot, Revue Bryologique 40: 20. 1913. Tipo: Brasil, Goiás, Mósen 451 (Isótipo: JE!).

\subsection{Chryso-hypnum caudiforme (Müll. Hal.) Moura, Comb. nov.}

Basiônimo: Hypnum caudiforme Müll. Hal., Flora 69: 524. 1886. Microthamnium caudiforme (Müll. Hal.) Kindberg, Enumeratio Bryinearum Exoticarum, supplementum 2, 101. 1891. Mittenothamnium caudiforme (Müll. Hal.) cardot, Revue Bryologique 40: 21. 1913. Tipo: Angola, Westafrika: Mossamedes, Danckelmann s.n. (Isótipo: PC!). 
8.3. Chryso-hypnum hylophilum (Müll. Hal.) Moura, Comb. nov.

Basiônimo: Microthamnium hylophilum Müll. Hal., Hedwigia 36: 135. 1897. Mittenothamnium hylophilum (Müll. Hal.) Cardot, Revue Bryologique 40: 21. 1913. Tipo: Argentina, Salta: Wald bei Orán, Lorentz s.n. (Isótipo: NY!).

\subsection{Chryso-hypnum nanopolymorphum (Müll. Hal.) Moura, Comb. nov.}

Basiônimo: Hypnum nano-polymorphum Müll. Hal., Linnaea 42: 498.1879. Microthamnium nanopolymorphum (Müll. Hal.) Brotherus, Die Natürlichen Pflanzenfamilien I(3): 1049. 1908. Mittenothamnium nanopolymorphum (Müll. Hal.) Cardot, Revue Bryologique 40: 21. 1913. Tipo: Venezuela, Coloniam Tovar, Fendler 151 (Isótipo: NY!).

\subsection{Chryso-hypnum overlaetti (Thér. \& Naveau) Moura, Comb. nov.}

Basiônimo: Mittenothamnium overlaetti Thér. \& Naveau, Mélanges Bryologiques et Lichénologiques 80. 1942. Tipo: Congo, Congo Belge: Lulua, cortic. [bij bron Tshii, oevenood], Overlaet s.n. (Holótipo: P!).

\subsection{Chryso-hypnum reduncum (Schimp. ex Mitt.) Moura, Comb. Nov.}

Basiônimo: Ctenidium reduncum Schimp. ex Mitt., Journal of the Linnean Society, Botany 12: 509. 1869. Hypnum reduncum (Schimp. ex Mitt.) Schimp., Bericht über die Thätigkeit der St. Gallischen Naturwissenschaftlichen Gesellschaft 1877-78: 330 (Gen. Sp. Musc. 2: 594). 1880. Hygrohypnum reduncum (Schimp. ex Mitt.) N. Nishimura, Journal of the Hattori Botanical Laboratory 58: 73. 1985. Mittenothamnium reduncum (Schimp. ex Mitt.) Ochyra, Fragmenta Floristica et Geobotanica 44: 256. 1999. Tipo: Peru, Tachapata, Lechler 3103, 3108 (Lectótipo: BM!, Isolectótipo: BM!).

Hygrohypnum circinatum Herzog, Memoranda Societatis pro Fauna et Flora Fennica 25: 51. f. 5: a-h. 1950. Mittenothamnium circinatum (Herzog) Ochyra, Fragmenta Floristica et Geobotanica 44: 256. 1999. Tipo: Brasil, Rio Grande do Sul, Sehnem s. $n$ (Holótipo: JE, Isótipo: PC!). 
Notas nomenclaturais: Nishimura (1985) analisou a amostra do material tipo de Mittenothamnium reduncum disponível em BM (BM000671718, Lechler 3108) e a definiu como sendo holótipo de Ctenidium reduncum. Hedenäs em 2000 analisou o mesmo material analisado por Nishimura e resolveu lectotipificar essas amostras, publicando essa lectotipificação na flora neotrópica sobre Amblystegiaceae (Hedenäs 2003).

Essa espécie foi transferida, pelos autores deste trabalho, para Chryso-hypnum por não apresentar as características descritas para o gênero Mittenothamnium (Caulídio estipitado, pseudoparáfilo triangular a triangular-lanceolado e papilas sendo projetadas apenas no ápice da célula). Além disso, em estudos moleculares (Moura \& Câmara, in. prep.) os resultados obtidos mostraram que essa espécie aparece junta com um clado chamado informalmente de Pseudochryso-hypnum. Contudo o clado Pseudochrysohypnum permaneceu junto com a família Amblystegiaceae e longe do clado Chrysohypnum.

\subsection{Chryso-hypnum subcampaniforme (Geh. \& Hampe) Moura, Comb. nov.}

Basiônimo: Hypnum subcampaniforme Geh. \& Hampe, Videnskabelige Meddelelser fra Dansk Naturhistorisk Forening i Kjøbenhavn ser. 4, 1: 145. 1879. Microthamnium subcampaniforme (Geh. \& Hampe) Kindberg, Enumeratio Bryinearum Exoticarum, supplementum 2, 101. 1891. Mittenothamnium subcampaniforme (Geh. \& Hampe) Cardot, Revue Bryologique 40: 21. 1913. Tipo: Brasil, São Paulo, Puiggari 3 (Lectótipo: BM! Designado aqui, Isolectótipo: BM!).

\subsection{Chryso-hypnum subdiminutivum (Geh. \& Hampe) Moura, Comb. nov.}

Basiônimo: Hypnum subdiminutivum Geh. \& Hampe, Videnskabelige Meddelelser fra Dansk Naturhistorisk Forening i Kjøbenhavn ser. 4, 1: 147. 1879. Stereohypnum subdiminutivum (Geh. \& Hampe) M. Fleischer, Hedwigia 47: 274, 291. 1908. Microthamnium subdiminutivum (Geh. \& Hampe) Kindberg, Enumeratio Bryinearum Exoticarum, supplementum 2, 101. 1891. Mittenothamnium subdiminutivum (Geh. \& Hampe) Cardot, Revue Bryologique 40: 21. 1913. Tipo: Brasil, São Paulo, Puiggari 968 (Lectótipo: BM! Designado aqui, Isolectótipo: BM!). 
Basiônimo: Hypnum caudiforme Müll. Hal., Flora 69: 524. 1886. Microthamnium caudiforme (Müll. Hal.) Kindberg, Enumeratio Bryinearum Exoticarum, supplementum 2, 101. 1891. Mittenothamnium caudiforme (Müll. Hal.) Cardot, Revue Bryologique 40: 21. 1913. Tipo: África, Danckelmann s.n. (Isótipo: P!).

\section{Agradecimentos}

Os autores agradecem aos curadores dos herbários investigados pelos empréstimos concedidos: Dra Barbara Thiers (NYBG), Jovita Yesilyurt (BM), Catherine Rausch (PC), Dr. Denilson F. Peralta (SP), Dr. Kátia Pôrto (UFP) e a Dra Anna Luiza Ilkiu-Borges (MG). Agradecimentos ao The New York Botanical Garden, ao Dr. Willian R. Buck, Dr. Bruce Allen e Dr. Magill pela recepção e auxílio durante o período do doutorado sanduíche da primeira autora. E a Instituição de fomento CAPES pela bolsa concedida.

\section{Referências Bibliográficas}

Anderson, L. E. 1954. Hoyer's solution as a rapid permanent mounting medium for bryologist. The Bryologist, 57: 242-244.

Bartram, E.B. 1949. Mosses of Guatemala. Fieldiana, Bot. 25: 1442.

Brummit, R. K. \& Powell. C. E. 1992. Authors of plant names. Kew: Royal Botanic.

Buck, W. R. 1984. Taxonomic and nomenclatural notes on West Indian Hypnaceae. Brittonia 36: 178-183.

Buck, W. R. 1993. Taxonomic Results of the Bryotrop Expedition to Zaire and Rwanda. Tropical Bryology 8: 199-217.

Buck, W. R. 1998. Pleurocarpous Mosses of West Indies. Memoirs of The New York Botanical Garden 82: 1-400.

Buck, W R. 2003. Guide to the Plants of Central French Guiana. Part 3. Mosses. Memoirs of the New York Botanical Garden, 76: 1-167.

Churchill, S. P. \& E. L. Linares. 1995. Prodromus bryologiae Novo-Granatensis: Introducción a la flora de musgos de Colombia. Parte 2: Grimmiaceae a Trachypodaceae. Biblioteca José Jerónimo Triana 2: 831-843. 
Churchill, S. P., Sanjines, A. N. N. \& Claudia Aldama, M. 2009. Catálogo de las Briofitas de Bolivia: Diversidad, Distribución y Ecología. Missouri Botanical Garden, 340 p.

Costa, D. P.; Pôrto, K. C.; Luizi-Ponzo, A. P.; Ilkiu-Borges, A. L.; Bastos, C. J. P.; Câmara, P. E. A. S.; Peralta, D. F.; Bôas-Bastos, S. B. V.; Henriques, D. K.; Gomes, H. C. S.; Rocha, L. M.; Vaz-Imbassahy, T. F.; Churchill, S. P. 2011. Synopsis of the Brazilian moss flora: checklist, distribution and conservation. Nova Hedwigia 93: 277-334.

Cox, C.J., Goffinet, B., Wickett, N.S., Boles, S. \& Shaw, J. 2010. Moss diversity: A molecular phylogenetics analysis of genera. Phytotaxa 9: 175-195.

Crum, H. \& Bartram, B. 1958. A survey of the moss flora of Jamaica. Bull. Inst. Jamaica Sci. Ser. 8:1-90.

Fleischer, M. 1908. Die Musci der Flora Von Buitenzorg. 4:i-xxxi, 1104-1729 [1923]. E. J. Brill, Leiden.

Florschütz-de Waard. J. \& Florschütz P. A. 1979. Estudios Sobre Criptógamas Colombianas III. Lista comentada de los Musgos de Colombia. The Bryologist. 82: 215-259.

Florschütz-de Waard, J. \& Veling, K. 1996. Flora of the Guianas. Royal Botanic Gardens, Kew. P. 439-461.

Germishuizen, G. \& Meyer, N.L. 2003. Plants of southern Africa: an annotated checklist. Strelitzia 14. National Botanical Institute, Pretoria.

Goffinet, B. \& Shaw, A. J. 2009. Bryophyte Biology. $2^{\text {nd }}$ edition. Cambridge University, Cambridge, Reino Unido. 119-120.

Gradstein, S.R.; Churchill, S.P. \& Salazar-Allen, N. 2001. Guide to the Bryophytes of Tropical America. Memoirs of the New York Botanical Garden 86: 1-577.

Hampe, E. L. 1879. Videnskabelige Meddelelser fra Dansk Naturhistorisk Forening i Kjøbenhavn ser. 4, 1: 143.

Hampe, E. L. 1910. Kongelige Norske Videnskabers Selskabs Skrifter. 3: 12.

Hedenäs, L. 2003. Amblystegiaceae (Musci). Flora Neotropica. Monograph 89: 1-107.

Hennings, P. C. 1902. Organ fur Kryptogamenkunde und Phytopathologie. Dresden. Hedwigia 41: 225.

Herzog, T. C. J. 1916. Bibliotheca Botanica 87: 147. 
Hornschuch, C. F. 1840. Flora Brasiliensis 2: 66.

Huttunen, S.; Bell, N.; Bobrova, V. K.; Buchbender, V.; Buck, W. R.; Cox, C. J.; Goffinet, B.; Hedenäs, L.; Ho B.; Ignatov, M. S.; Krug, M.; Kuznetsova, O.; Milyutina, I. A.; Newton, A.; Olsson, S.; Pokorny, L.; Shaw, J. A.; Stech, M.; Troisky, A.; Vanderpoorten, A. \& Quandt, D. 2012. Disentangling knots of rapid evolution: origin and diversification of the moss order Hypnales. Journal of Bryology, 3: 187-211.

IUCN. 2012. IUCN Red List Categories and Criteria: Version 3.1. Second edition. Gland, Switzerland and Cambridge, UK: IUCN. Iv + 32pp.

Magill, R. E. 1990. Glossarium polyglotum bryologiae: A multilingual glossary for bryology. Monograph in Systematic Botany from the Missouri Botanical Garden $33: 1-297$.

McNeill, J.; Barrie, F. R.; Buck, W. R.; Demoulin, V.; Greuter, W.; Hawksworth, D. L.; Herendeen, P. S.; Knapp, S.; Marhold, K.; Prado, J.; Prud'Homme Van Reine, W. F.; Smith. G. F. \& Wiersema, J. H. 2012. Código Internacional de Nomenclatura para algas, fungos e plantas (Código de Melbourne). Regnum Vegetabile 154: 1-207.

Mitten, G. Musci Austro-Americani. 1869. Missouri Botanical Garden, 1982, 7: 9-659.

Mönkemeyer, W. 1927. Die Laubmoose Europas. IV. Band, Ergänzungsband. Andreaeales-Bryales. Leipzig.

Müller, C. 1879. Linnaea, Berlin \& Halle. 42: 438.

Nishimura, N. 1985. A revision of the genus Ctenidium (Musci). J. Hattori Bot. Lab. 58: $1-82$.

Nishimura, N. \& Ando, H. 1986. A Revision of Some Mittenothamnium Species Described from Mexico. The Bryologist 89: 66-69.

Nishimura, N. \& Ando, H. 1994. Mittenothamnium. In: The Moss Flora of Mexico, Memoirs of The New York Botanical Garden 69: 1-1113.

Nishimura, N. \& Kanda, H. 1990. Mittenothamnium deguchii, a New Moss Species from Southern Chile. The Bryologist 3: 275-278.

Ochyra, R. 1999b. A new combination in neotropical mosses. Fragm. Florist. Geobot. 44: 255-259.

O' Shea, B. J. 2006. Checklist of the mosses of sub-Saharan Africa (version 5, 12/06). Tropical Bryology 6: 1-252. 
Petit, E. 1978. Key for the determination of families of Pleurocarpous mosses of Africa. D’Afrique. Bull. Jard. Bot. Nat. Belg. 48: 135-181.

Sayre, G. 1977. Authors of Names of Bryophytes and the Present Location of Their Herbaria. The Bryologist 80:502-521.

Schofieldt, W. B., Buck, W. R. \& Ireland Jr., R. R. 2014. In: Flora of North America. Oxford. 28: 515.

Sharp, A. J.; Crum, H. A.; \& Eckel, P. 1994. The Moss Flora of Mexico, Memoirs of The New York Botanical Garden 69: 1-1113.

Shaw, A. J., Cox, C. J. Goffinet, B., Buck, W. R. \& Boles, S. B. 2003. Phylogenetics evidence of a rapid radiation of Pleurocarpous mosses (Bryophyta). Evolution. 57: 2226-2241

Tsubota, H., N. Nakao, H. Akiyama, T. Yamaguchi, M. Higuchi, H. Deguchi, and T. Seki. 1999. A preliminary phylogeny of Hypnales (Musci) as inferred from chloroplast rbcL sequence data. Bryological Research. 7: 233-48.

Tropicos. < http://www.tropicos.org/> Acesso 2016.

Warnstorf, C. (1904-1906). Kryptogamenflora der Mark Brandenburg und angrenzender Gebiete. Laubmoose, Zweiter Band. Verlag von Gebrüder Borntraeger, Leipzig. 